\title{
KISEMLŐS KÖZÖSSÉGEK VIZSGÁLATA A LAJTA PROJECT ERDŐSÁVRENDSZERÉBEN
}

\author{
Németh Csaba \\ Örségi Nemzeti Park Igazgatóság \\ 9941 Öriszentpéter Siska szer 26/a
}

\begin{abstract}
Németh Cs.: InVESTigation on SMall Mammal Communities IN the LAJTA Project Forest Belt System. Hungarian Small Game Bulletin 12: 275-356. http://dx.doi.org/10.17243/mavk.2014.275

The author, during 6 years between 1992 and 1999 has examined by the trapping method the small mammal fauna of the LAJTA Project. In the first two years, the withdraw trapping (traditional mousetraps), later on wooden traps for live trapping were used. In the survey carried out in the forest belts, traps were installed according to the belt transect, at $10 \mathrm{~m}$ distance from each other, for 3 trapping nights, a total of 50 traps in each forest belt. In live trapping, both no-marking and Capture-Mark-Recapture (CMR) techniques were used. In 1999 the small mammal community of forest belts and the neighbouring cultures were studied in August, September and October, with 4 trapping-nights by square method $(7 \times 7$ traps). In data collection, the capture place, species, age, sex and weight of captured animals were registered. Animals collected by withdraw trapping underwent a biometrical data registration (body length, ear length, tail length, hind legs' length).

In description of small mammal habitats, the results of the method locally developed formerly for registering the habitat characteristics for bird communities was used; in case of habitats assessed by square method, this has been supplemented with the shrub and grass levels' detailed species coverage (A-D\%) assessment.

It has been proved that within field protecting forest belts in agricultural areas, beyond the generally widespread rodent species and communities (Microtus arvalis, Cricetus cricetus), the three generalist rodent species of the European temperate zone form a stable population (Apodemus sylvaticus, Apodemus flavicollis, Clethryonomis glareolus), owing to which, special, transitional small mammal communities are forming. Within the communities, the dominance of the Common Wood Mouse is characteristic. Most often the Common Vole is the competitor, while in the forest patches this is the Apodemus flavicollis.

The Apodemus flavicollis is strongly bound to the tree vegetation, as opposed to the Apodemus sylvaticus that is also widespread in agricultural areas with cultivated steppe character too.

In the area of the Robinia patch, during three summer and autumn months the sex proportion of the two Apodemus species is changing in opposite direction, which is a result of competition of species using the same resources and is characteristic to stable communities. Similarly, in the area of the forest belts, the above two species' quantity relations are also changing oppositely, as a result of the competition conditions.

The mouse (Muridae) and vole species (Arvicolidae) populations' mean body weight values have reached their maximum in different years, which refers to different food resource utilisation.

Several neighbouring habitats of similar structure and with similar small mammal communities prove that there is a connection between the vegetation structure and small mammal communities; this has also been proved by the mosaicism examinations.

It has been proved that from the inside of the forest belts toward the agricultural cultures the species number and diversity of the small mammal populations decrease (exponentially and linearly, respectively) and at the same time these features did not show trend-like changes in the Robinia forest patch.

During the examination on the species composition rearrangement it has been proved that the small forest mammal species would not be able to colonize the isle-like forest patches in agricultural areas without the ecological corridor role of the field protecting forest belts.
\end{abstract}

KULCSSZAVAK: LAJTA Project, kisemlős közösségek, vegetácó szerkezet, ökológiai folyosó

KEY WORDS: LAJTA Project, small mammal communities, vegetation structure, ecological corridor 


\section{BEVEZETÉS}

A Föld folyamatosan gyarapodó népessége élelemhez való juttatásának kényszere miatt egyre nagyobb és nagyobb területeket vontak mezőgazdasági müvelés alá szerte a világban, így Magyarországon is. E folyamat föként Európában a természetes ökoszisztémák csaknem teljes eltủnéséhez, vagy nagymértékü degradálódásához vezetett (FARAGÓ, 1997a). Ugyanakkor a Természetvédelmi Világstratégia (IUCN, UNEP, WWF, 1980) kiadása óta eltelt két évtized alatt rohamosan fejlődő észlelőhálózat és értékelő apparátus világosan igazolta, hogy a hagyományosan, rezervátumokban és fajmentő akciókban gondolkodó természetvédelem nem képes megfelelni a Stratégia követelményeinek (NÉMETH, 1995b), főként a genetikai diverzitás védelme, és a fajok, ökoszisztémák fenntartható használata terén. Ennek alapvető oka, hogy az érintetlen, természetes élőhelyek kiterjedése erősen korlátozott.

Magyarországon a természetes élőhelyek térszerkezete már nem található meg, mert azt felszabdalta az emberi tevékenység által elfoglalt és átalakított tér. Ma már nem ez utóbbi illeszkedik be a természetes rendszerekbe, hanem éppen ellenkezőleg, a humán tevékenység által elfoglalt térben találhatók meg a természetes, vagy természetközeli élőhelyek szigetei (GYULAI, 1996). Szemléletesen jelzi ezt az a tény, mely szerint az 1990-es évek elején hazánk területének mintegy felét szántóként tartották nyilván (MÁRKUS, 1992). Ugyan az idöközben eltelt egy évtized gazdasági tapasztalatai és a velük szorosan összefüggő Európai Uniós elvárások alapján megjósolható, hogy ez a szántóterület hozzávetőlegesen egymillió hektárral kisebb lesz a jövőben (HARASZTHY, 1999), nem vitatható, hogy részaránya a földhasználati formák közül továbbra is az egyik meghatározó marad.

A mezőgazdasági müvelésben maradó területek használatával kapcsolatban úgy általánosságban (KTM, 1991), mint a konkrét elemzésekben (MÁRKUS, 1996) megfogalmazásra kerül a fenntarthatóság, az optimális hasznosítás szükségessége. Ennek részeként az egykor természetes életterek felszámolásával kialakított szántóterületeken olyan élőhely-mozaikokat kell létrehozni vagy fenntartani, amelyek a mezőgazdasági termelést gátló környezeti hatások (defláció, erózió, szárazság, stb.) mérséklésén túl a természetes élővilág fennmaradását és visszatelepedését is szolgálják (HARASZTHY, 1995). Ilyen lehetséges élőhelyek a mikro- és mezoklimatikus, valamint eróziót csökkentő hatásaik miatt létrehozott mezővédő erdősávok is.

Dolgozatomban egy intenzív agrárkörnyezetben kialakított mezővédő erdősávrendszer, a LAJTA Project kisemlős közösségeinek hét éves időszakot átfogó vizsgálati eredményeit ismertetem. 1992. és 1999. között folytatott kutatásaim során igyekeztem feltárni az érintett terület talajon élő rágcsáló (Rodentia) és rovarevő (Insectivora) kisemlősfaunáját, a különböző élőhelyek kisemlős közösségeinek szerkezeti jellemzőit, azok vegetációs perióduson belüli és évek közötti változásait. Vizsgálataim első éveiben a kisemlős közösségek és élőhelyük szerkezete közti összefüggések tisztázására fektettem hangsúlyt, később pedig szükebben vett szakmám -a természetvédelem- számára gyakorlatban hasznosítható eredmények érdekében a szegélyhatás és izoláció kérdéseit vizsgáltam a kisemlösök példáján, feltárva az erdősáv-rendszer zöld folyosó szerepét a kisemlős metapopulációk fenntartásában. Az utóbbi problémakör feltárásával igyekszem hozzájárulni a Nemzeti Ökológiai Hálózat emlősfajok természetvédelmére gyakorolt pozitív hatásának hangsúlyozásához. 


\section{ANYAG ÉS MÓDSZER}

\subsection{A terepi adatgyüjtés módszerei}

A LAJTA Project területén 1992-ben megkezdett kisemlős vizsgálataim célja kezdetben a talajlakó kisemlősfauna (Insectivora, Rodentia) lehető legteljesebb körü feltárása volt. Az első csapdázások eredményei később ökológiai jellegű vizsgálatokat indukáltak. Fentiek miatt 1992-ben és 1993-ban a faunisztikai célú vizsgálatok minél nagyobb számú erdősáv csapdázását tették szükségessé, míg 1994. és 1999. között a hangsúly inkább az egy területre való többszöri visszatérésre helyeződött. A szakirodalom (KöLÜs, 1969, PALOTÁs, 1986, HORVÁTH, 1998a, 1998b) különféle csapdázási hálózatokat - kvadrátokat, vonalakat, koncentrikus köröket -, csapdaszámokat - 81, 121, 320 - és időtartamot (3, 4, 5 éjszakás csapdázás) próbál ki, illetve javasol a kisemlősök fogására. Ugyanakkor már BALOGH (1958, idézi KöLÜS, 1969) is rámutatott, hogy csak több sorozatú, legalább 3-3 napi exponálás mellett, a környezeti viszonyoknak megfelelő, többféle módszer adhat értékelhető eredményt. Figyelemmel a fentiekre, a kutatások során, a vizsgált élőhelyek „,vonalas” térbeli kiterjedését legjobban követő vonal transzekt (HORVÁTH, 1998a, 2001) alkalmazása mellett döntöttem, melyen csak 1999-ben változtattam, amikor az erdősávokat határoló mezőgazdasági kultúrák vizsgálata is célom volt. Ekkor kvadrát módszert (HORVÁTH \& KALMÁR, 2001) használtam. Csapdaszám tekintetében az 50 csapda/erdősáv értéket választottam, mivel így a vonal transzekt, az átlagosan $1 \mathrm{~km}$ hosszú erdősávokat fele hosszukban lefedte. A terepi adatgyüjtés módszereit a vizsgálati évek bontásában ismertetem részletesen.

1992.

1992. július 9. és 17. között 16 erdösávban végeztem csapdázásokat (1. térkép). Hagyományos egérfogók - elvonó csapdázás - alkalmazásával három éjszakán keresztül fogtam a kisemlősöket. Egy erdősávban 50 csapdát helyeztem el lineárisan, egymástól 10-10 m távolságra. A könnyebb megtalálhatóság érdekében a csapdákat fák, illetve cserjék tövében tettem le, a felettük lévő ágat pedig papírszalaggal jelöltem meg. A csapdavonal a vizsgált erdősávok hossztengelyében helyezkedett el. Az állatokat vászonzacskóban szállítottam a LAJTA-Project kutatóházába. Az adatfelvétel során feljegyeztem a lelőhelyet (erdősáv és csapdaszám), dátumot, az állat faját (CORBET \& OVENDEN, 1982, UJHELYI, 1994), korát és ivarát. A kor határozásánál teljes testméretüket még el nem ért, kevéssé fejlett genitáliákkal rendelkező juvenilis és kifejlett adult egyedeket különítettem el. A testtömeget $1 \mathrm{~g}$ pontosságú levélmérlegen mértem.

Biometriai adatfelvételezést is végeztem a populációkat jellemző testméretek megállapítása céljából. 1 milliméteres pontossággal mértem a testhosszot (TH), a farok tövétől az orr hegyéig; a farokhosszt (FH), a farok tövétől a farok hegyéig, a farokszőr nélkül; a hátsó talp hosszát $(\mathrm{TaH})$, a sarokizülettől a leghosszabb új végéig, karom nélkül; valamint a fülhosszt, a fül leghátsó pontjától a kagyló belső hajlatáig. A gravid nőstény egyedeket felboncoltam és megállapítottam az embriók számát, a laktáló nőstények esetében pedig a szopott emlők számát is regisztráltam.

1993.

1993-ban, 7 erdősávban végeztem csapdázásokat (2. térkép), melyek módszere az 1992. évnél ismertetettekkel egyezik meg. 
1994.

1994. július 27. és augusztus 8. között 15 erdősávban végeztem csapdázásokat (3. térkép). Fából készült élvefogó ládacsapdák alkalmazásával három éjszakán keresztül fogtam a kisemlősöket. Egy erdősávban 50 csapdát helyeztem el lineárisan, egymástól 10-10 m távolságra. A csapdavonal a vizsgált erdősávok hossztengelyében helyezkedett el. Az adatfelvétel során, melyet a fogás helyszínén végeztem, feljegyeztem a lelőhelyet (erdősáv és csapdaszám), dátumot, az állat faját, korát és ivarát. A testtömeget $1 \mathrm{~g}$ pontosságú Pesola rugós mérlegen mértem. Az állatokat az adatfelvételt követően azonnal szabadon engedtem, jelölést nem alkalmaztam.

1996.

1996-ban május és július hónapokban, 6 erdősávban végeztem csapdázásokat (4. térkép). Fából készült élvefogó ládacsapdák alkalmazásával három éjszakán keresztül fogtam a kisemlösöket. Egy erdősávban 50 csapdát helyeztem el lineárisan, egymástól 10-10 m távolságra. A csapdavonal a vizsgált erdősávok hossztengelyében helyezkedett el. Az adatfelvétel során, melyet a fogás helyszínén végeztem, feljegyeztem a lelőhelyet (erdősáv és csapdaszám), dátumot, az állat faját, korát és ivarát. A testtömeget $1 \mathrm{~g}$ pontosságú Pesola rugós mérlegen mértem. Az állatokat az adatfelvételt követően azonnal szabadon engedtem, jelölést nem alkalmaztam.

1997.

1997-ben augusztus 16. és 24. között 15 erdősávban végeztem csapdázásokat (5. térkép). Fából készült élvefogó ládacsapdák alkalmazásával három éjszakán keresztül fogtam a kisemlösöket. Egy erdősávban 50 csapdát helyeztem el lineárisan, egymástól 10-10 m távolságra. A csapdavonal a vizsgált erdősávok hossztengelyében helyezkedett el. Az adatfelvétel során, melyet a fogás helyszínén végeztem, feljegyeztem a lelőhelyet (erdősáv és csapdaszám), dátumot, az állat faját, korát és ivarát. A testtömeget $1 \mathrm{~g}$ pontosságú Pesola rugós mérlegen mértem. Az állatokat az adatfelvételt követően azonnal szabadon engedtem.

Fogás-jelölés-visszafogás (CMR) módszert alkalmaztam, az első lábujjperc eltávolításával egyedileg jelöltem az állatokat (BEGON, 1979, O’FARELL, 1980; NICHOLS \& CONLEY, 1982). A módszer előnye, hogy a természetben gyakran előforduló ilyen jellegü sérülésekhez hasonlóan nem jár az állat számára hátrányos következményekkel, ugyanakkor könnyen azonosítható, tartós jelölést biztosít.

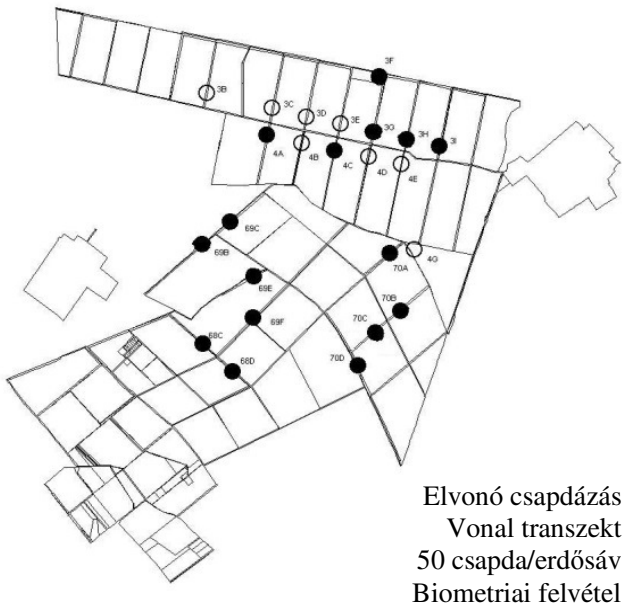

1. térkép: Az 1992-ben vizsgált erdősávok

Map 1: Forest belts examined in 1992

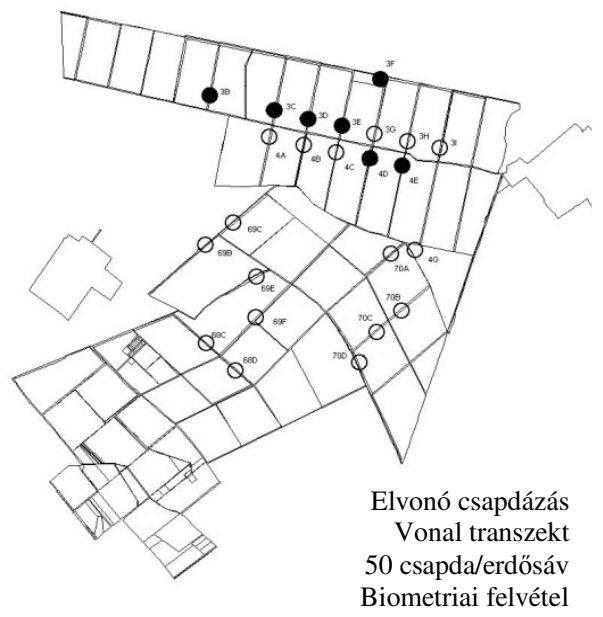

2. térkép: Az 1993-ban vizsgált erdősávok

Map 2: Forest belts examined in 1993 


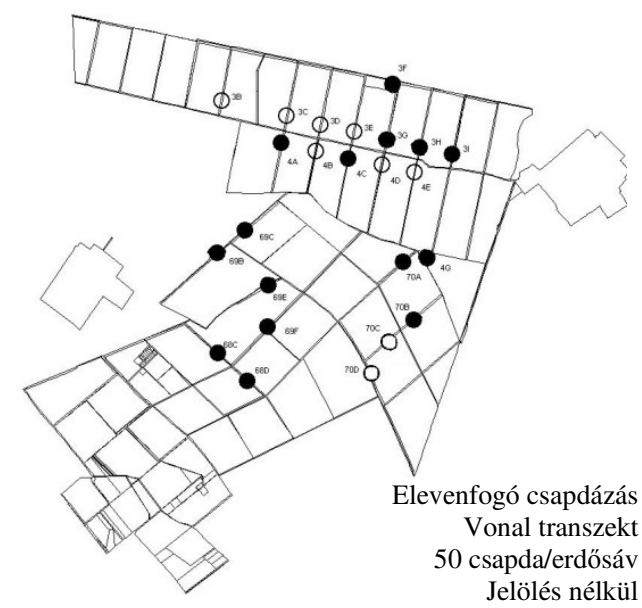

\section{3. térkép: Az 1994-ben vizsgált} erdősávok

Map 3: Forest belts examined in 1994

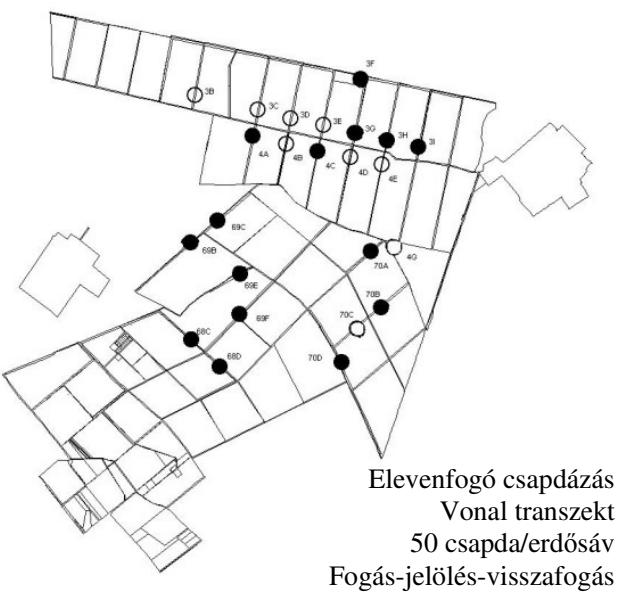

\section{5. térkép: Az 1997-ben vizsgált erdősávok}

Map 5: Forest belts examined in 1997

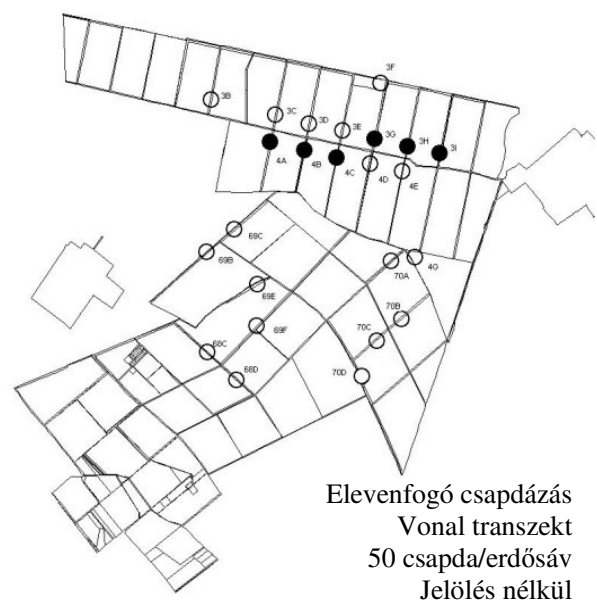
4. térkép: Az 1996-ban vizsgált
erdősávok

Map 4: Forest belts examined in 1996

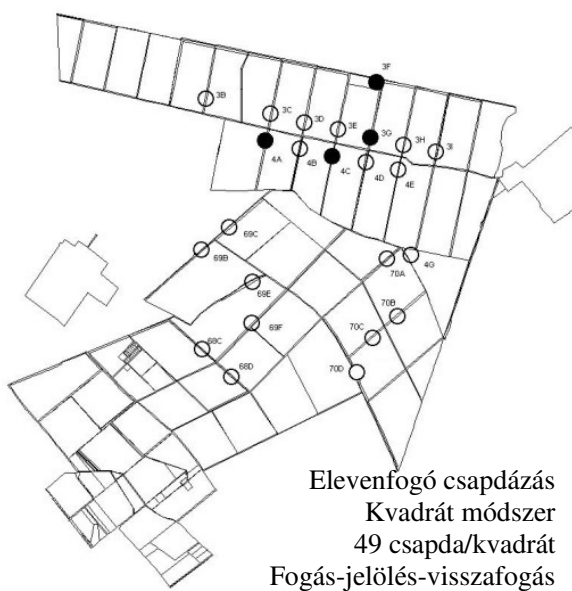

6. térkép: Az 1999-ben vizsgált kvadrátok

Map 6: Forest belts examined in 1999

1999.

1999-ben, július, augusztus és szeptember hónapban, 4 erdősávban végeztem csapdázásokat (6. térkép). Fából készült élvefogó ládacsapdák alkalmazásával, havonta négy éjszakán keresztül fogtam a kisemlősöket. Kvadrát módszert alkalmaztam, $7 \cdot 7=49$ csapdával, melyek egymástól 10-10 m távolságra kerültek lerakásra. A kvadrátokon belül az egyes csapdák helyét számozott cövekekkel állandósítottam. Az adatfelvétel és a jelölés módszere az 1997. évnél ismertetettekkel egyezik meg.

\section{A csapdák csalizása}

A csapdák csalizása tekintetében az irodalom gazdag választékkal szolgál. SzUNYOGHY (1955) szerint - " Csalétkül legjobban bevált a dióbél." KöLÜs (1969) pirított szalonnát, avas 
dióbelet áztatott kukoricaszemet, PALOTÁs (1986) ezek mellett pirított tökmagot használt. HORVÁTH \& LANSZKI (2000) szalonnát, valamint ánizskivonattal, dióőrleménnyel, növényi olajjal kevert gabonamagvakat alkalmazott csalétekként.

Vizsgálataimban pozsonyi kutatók javaslatára (BINDER HELGA szóbeli közlése) a következő módszert alkalmaztam: apróra vágott dióbelet főztem össze margarinnal, és az így elkészült főzettel petróleumlámpa-bél darabkákat itattam át. A kapott $1 \mathrm{~cm}$ nagyságú csalikat helyeztem el a csapdákban. A felitatott főzet illata tapasztalataim szerint minden rágcsáló és rovarevő kisemlőst vonz a közelbe, és a fogás utáni felcsalizás is egyszerü. Amennyiben a csalit csak megrágják az állatok, a főzettel való átkenés újra aktívvá teszi a csapdát. A módszer eredményességét HORVÁTH GYÖZÖ és JÁNOSKA FERENC vizsgálatai is megerősítették (szóbeli közlés).

\subsection{Az adatfeldolgozás módszerei}

\subsubsection{A populáció szintű vizsgálatok módszerei}

A terepen felvett csapdázási jegyzőkönyveket Microsoft Excell 2002 táblázatkezelő programban tároltam és dolgoztam fel.

A populáció szintű vizsgálatok során az alábbi jellemzőket határoztam meg fajonként:

\section{A populáció biometriai jellemzői}

A vizsgálati területén élő kisemlős fajok populációinak morfológiai jellemzésére a biometriai adatfelvételek eredményeit használtam fel. Az 1992-ben és 93-ban felvett testméretek alapján kiszámoltam a testhossz, farokhossz, hátsó talphossz, fülhossz fajonkénti átlagértékeit, szórását, konfidencia intervallumát, továbbá feltüntettem minimális és maximális értékeiket. Összehasonlításul megadom az irodalomból ismert értékeket.

\section{Mikrohabitat használat}

A mikrohabitatok növényzetének kisemlős fajok elterjedésére gyakorolt hatását vizsgálandó, összehasonlítottam fajonként a kisemlős mikrohabitatok fogási adatait. Az 1999-ben vizsgált, $7 \times 7$ csapdából álló kvadrátok minden erdősávval párhuzamos -és éppen ezért homogénnek tekinthető növényzeti jellemzőkkel bíró- csapdasorát tekintettem önálló mikrohabitatnak.

A reprezentatív mintatvételt szem előtt tartva, egy grafikonon szerepeltettem mind a négy -1999-ben vizsgált- kvadrát összes mikrohabitatját. Az összehasonlításhoz $\chi^{2}$-próbát alkalmaztam (FOWLER \& COHEN, 1992; PRÉCSÉNYI, 1995).

\section{Az ivararány alakulása egy szaporodási időszakon belül}

Korábbi vizsgálataim során 1992 és 1994 nyarán, egy-egy alkalommal történt csapdázásokkal a rágcsáló kisemlős fajok populációiban hím többséget mutattam ki (NÉMETH, 1995a). Ugyanakkor PELIKÁN (1970) vizsgálataiból ismert, hogy a hím egyedek populáción belüli aránya egy szaporodási időszakon (éven) belül jelentős eltéréseket mutat. A jelenség vizsgálata céljából, 1999-ben havonként fogott hím egyedek számát elosztottam a nőstények fogásszámával. Az így kapott arány logaritmusát ábrázoltam havonta, mind a négy, 1999-ben vizsgált kvadrát esetében (HORVÁTH \& KALMÁR, 2001). Az ivararány változásokat páronként korrelációval hasonlítottam össze (PRÉCSÉNYI, 1995). Az 1-hez közeli korrelációs koeficiensek esetében t-teszttel végeztem szignifikancia vizsgálatot. 


\section{Az egy csapdára jutó átlagos fogásszám alakulása egy szaporodási időszakon belül, kvadrátonként}

A rágcsáló kisemlősök szaporodási időszakon belüli egyedszám változásának elemzése nélkül az egyes évek közti egyedszám dinamika is nehezen értelmezhető (NIETHAMMER \& KRAPP, 1982). Az 1999-ben vizsgált négy kvadrát esetében havonta, varianciaanalízissel (one-way ANOVA) hasonlítottam össze az egy csapdára jutó átlagos fogásszám értékeket. Ahol a varianciaanalízis különbséget jelzett, ott az egyenlő mintanagyságokra alkalmazható TUKEY HSD teszttel végeztem szignifikancia vizsgálatot (PRÉCSÉNYI, 1995).

\section{Az egyes kvadrátok összehasonlítása az egy csapdára jutó átlagos fogásszám alapján, egy hónapon belül}

A különböző habitatok ugyanabban az időszakban jelentősen eltérő mennyiségü kisemlöst tarthatnak el egy fajból (HORVÁTH \& KALMÁR, 2001). Az 1999-ben vizsgált négy kvadrátot havonként egymással is összehasonlítottam az egy csapdára jutó átlagos fogásszám alapján varianciaanalízissel (one-way ANOVA). Ahol a varianciaanalízis különbséget jelzett, ott az egyenlő mintanagyságokra alkalmazható TUKEY HSD teszttel végeztem szignifikancia vizsgálatot (PRÉCSÉNYI, 1995; HORVÁTH et al., 1996b).

\section{A visszafogási ráta alakulása egy vegetációs perióduson belül}

Ahol értékelhető mennyiségü adat állt rendelkezésre, a visszafogások számát elosztva az összes fogással visszafogási ráta értékeket számoltam, melyeket havonta, kvadrátonként ábrázoltam.

\section{A fogás-visszafogás események térbeli alakulása}

A fogás-visszafogás események az állatok térbeli mozgásának leírására alkalmasak. A csapdák állandó távolsága $(10 \mathrm{~m})$ számszerüsíthetővé teszi az elmozdulás mértékét. A kvadrátok elhelyezése úgy történt, hogy a fogás és a visszafogás helye közti vektor egyszerüen felbontható legyen egy erdősávval párhuzamos, és egy arra merőleges komponensre. Kvadrátonként meghatározva az állatok mozgásának átlagos vektorkomponenseit, kimutathatóvá vált a mozgás jellemző iránya.

\section{Évek közti dinamika vizsgálata az erdősávokban}

A több évig tartó terepi vizsgálatok alapján, a kisemlős populációkat jellemző évek közti dinamika feltárása céljából a 100 csapdaéjszakára (1csapdaéjszaka= 1 csapda 1 éjszakán át történö használata) jutó egyedszám dinamikáját vizsgáltam 1992. és 1999. között (HORVÁTH \& LANSZKI, 2000, LELKES \& HORVÁTH, 2000). Így kiküszöböltem a 3, ill. 4 éjszakás csapdázással vizsgált évek közti hibalehetőséget. Mivel elvonó és élvefogó (jelölés nélküli és CMR) technikát is alkalmaztam, csak a fogott egyedek számával számoltam, a visszafogást nem vettem figyelembe. Az 1999-es adatoknál csak az erdősávba eső kvadrátrészek eredményeit vontam be a vizsgálatba. A fentiek szerint kapott értékekre regresszióanalízissel illesztettem trendvonalat. 


\section{A populációk egyedeinek térbeli mintázata}

Elemeztem fajonként az egyedek habitaton belüli elterjedésének tendenciáit. A populáció egyes egyedei által használt csapdákat, mint mintavételi egységeket tekintve, a különböző csapdákban megfogott egyedek száma alapján csapdázási időszakonként számoltam a Lloydféle ,átlagos zsúfoltsági indexet” (Index of Mean Crowing = IMC) (LLOYD, 1967):

$$
\stackrel{*}{m}=m+\left(\frac{s^{2}}{m}-1\right)
$$

ahol $\mathrm{s}^{2}$ a minta varianciája és $\mathrm{m}$ a kvadrát valamennyi csapdáját tekintve az adott faj egyedeinek átlagos fogásszáma, vagyis

$$
m=\frac{N}{n} .
$$

A képletben $\mathrm{N}$ a faj adott csapdázási hónapban megfogásra kerülő egyedeinek száma és $\mathrm{n}$ a mintavételi kvadrát csapdaszáma. Ha az eloszlás megfelel a Poisson-eloszlásnak, akkor a $\mathrm{s}^{2} / \mathrm{m}$ hányados értéke 1 , azaz $\stackrel{*}{m}=\mathrm{m}$.

A fentiek felhasználásával az átlagos csoportosulás és az átlagos denzitás hányadosaként minden csapdázási hónapra számítottam a Lloyd-féle "foltosság" (patchiness) értékét, melyet táblázatos formában adok meg:

$$
\frac{m}{m}
$$

Ha a hányados értéke 1, az egyedek térbeli eloszlása véletlenszerü. Ha a foltosság értéke 1nél nagyobb, akkor a populáció egyedei aggregáltságot, ha kisebb 1-nél, szegregáltságot mutatnak.

\section{Az átlagos testtömeg alakulása az évek viszonylatában}

Összevonva az egyes mintavételi helyeket, évenként vizsgáltam az átlagos testtömeg alakulását, melynek ábrázolásakor az átlag standard hibáját is feltüntettem. Feltételezve, hogy a vizsgált években az egyedek ivari és kor eloszlása a csapdázási időszak állandósága következtében hasonló, egyfaktoros varianciaanalízissel (one-way ANOVA) végeztem összehasonlítást. Ahol a varianciaanalízis különbséget jelzett, ott a különböző mintanagyságokra alkalmazható TUKEY teszttel számoltam szignifikanciát (PRÉCSÉNYI, 1995).

A kisemlős fajok projekten belüli előfordulásának térképi ábrázolása HóBER (2002) munkájának felhasználásával történt.

\section{2. 2. A közösségi szintü vizsgálatok módszerei}

Egy kisemlős közösségként kezeltem egy erdősáv, egy csapdázási periódusban (3 vagy 4 éjszakán át) csapdázott kisemlőseinek összességét. A vizsgált 24 erdősávban így 76 kisemlős közösséget regisztráltam. Összehasonlítottam a habitatok csapdázási periódusonként feltárt kisemlős közösségeinek dominancia viszonyait, denzitását, fajszámát, SHANNON-WEAVER (1949) diverzitását és egyenletességét (PIELOU, 1966). 
Az ábrákon alkalmazott rövidítések jelentése:

$\begin{array}{lll}\text { SORARA } & - & \text { Erdei cickány } \\ \text { SORMIN } & - & \text { Törpecickány } \\ \text { CROLEU } & - & \text { Mezei cickány } \\ \text { APOSYL } & - & \text { Közönséges erdeiegér } \\ \text { APOFLA } & - & \text { Sárganyakú erdeiegér } \\ \text { MICMIN } & - & \text { Törpeegér } \\ \text { MICARV } & - & \text { Mezei pocok } \\ \text { CLEGLA } & - & \text { Vöröshátú erdeipocok } \\ \text { MUSSPI } & - & \text { Güzüegér } \\ \text { PYTSUB } & - & \text { Földipocok } \\ \text { CRICRI } & - & \text { Közönséges hörcsög }\end{array}$

Négy habitat esetében a diverzitás időbeli változását vizsgálandó, a csapdázási periódusonként kapott értékeket páronként t-teszttel vetettem össze. Ahol a t-teszt szignifikáns eltérést jelzett az értékpárok között, ott a diverzitás skálafüggő jellemzésére szolgáló Rényi-féle diverzitási rendezést (TóTHMÉRÉSZ, 1996) is elvégeztem (HoRVÁTH \& PINTÉR, 2000). Az egymás diverzitási profilját nem metsző diverzitási görbék esetében tekintettem az összehasonlított közösségeket diverzitás szerint rendezhetőnek, valamint diverzebbnek azt a közösséget, melynek görbéje fentebb futott. Amennyiben a közösségek profiljai a kezdőértéknél találkoztak, faj-abundancia görbéik alapján is megvizsgáltam viszonyukat.

A közösségek és az élőhelyszerkezet közti összefüggések tisztázására clusteranalízist alkalmaztam (PALOTÁs, 1986). A közösségek szerkezetét reprezentáló alapmátrixokat a kisemlősök élöhelyenkénti dominancia viszonyaiból származtattam. Az élöhelyek, mint vegetációs egységek összevetésére JÁNOSKA (1995b) felvételei alapján került sor.

A fúziós stratégiát az Eltérésnégyzetösszeg-növekedés minimalizálása módszer szolgáltatta (WARD, 1963; ORLÓCZI, 1967; WiSHART, 1969 idézi PODANI, 1997), amely a hierarchikus osztályozás talán legismertebb és legáltalánosabban alkalmazott módszere. Két csoport összevonásának az a feltétele, hogy az a lehetö legkisebb eltérésnégyzet-növekedéssel járjon. Az alkalmazott hasonlósági formula az Euklidészi távolság módszer volt:

$$
\mathrm{EU}_{\mathrm{jk}}=\left[\Sigma\left(\mathrm{x}_{\mathrm{ij}}-\mathrm{X}_{\mathrm{ik}}\right)^{2}\right]^{1 / 2}
$$

Ahol $\mathrm{x}_{\mathrm{ij}}$ és $\mathrm{x}_{\mathrm{ik}}$ az $\mathrm{i}$ faj gyakorisága a j. és a k. közösségben.

Az 1999-ben vizsgált kvadrátokban a kisemlős közösség és a vegetáció mozaikosságának mérésére a WHITTAKER (1960, idézi TÓTHMÉRÉSZ, 1998)-féle $\beta$-diverzitást alkalmaztam:

$$
\beta_{\mathrm{W}}=[\mathrm{ST} / \operatorname{aver}(\mathrm{S})]-1
$$

Ahol aver(S) az egy csapdasorra jutó átlagos fajszám, ST pedig a kvadrát teljes fajszáma. Ha minden faj előfordult minden csapdasorban, akkor a $\beta_{\mathrm{W}}=0$. Minél kevesebb faj van jelen az egyes csapdasorokban a teljes fajkészletből, annál nagyobb lesz a $\beta_{\mathrm{W}}$ értéke (TóTHMÉRÉSZ, 1998).

A statisztikai elemzések során a NuCoSa1.0 (TóTHMÉRÉSZ, 1996) és a Microsoft Windows Statistica programokat használtam. 


\section{A KUTATÁSI TERÜLET JELLEMZÉSE}

\subsection{A LAJTA Project általános jellemzése}

A LAJTA Project Magyarország ÉNY-i részén, földrajzilag a Kisalföld nagytájunkon belül, a Győri-medence középtáj részét képező Mosoni-síkság kistájon, annak is a Hanság medencéjével érintkező déli felén helyezkedik el.

Domborzatát tekintve a kistáj teljes egészében magasártéri helyzetü hordalékkúpsíkság. Tengeszint feletti magassága ÉNy-on 125-130 m, DK-en 110-115 m között változik, általános DK-i lejtéssel. A relatív relief csak az ÉNy-i határmenti területen haladja meg az $5 \mathrm{~m} / \mathrm{km}^{2}$-t. Az alacsony szintkülönbségek mellett völgyhálózat nem jöhetett létre, a felszínt csak a vízfolyások medrei tagolják. Földtanilag a terület a Kisalföld süllyedő medencéjébe épült dunai hordalékkúp D-i lejtővidéke. Felszínét jelenkori folyóvízi iszap, a Lajta két oldalán folyóvízi kavics, attól D-re és DK-re iszapos-löszös üledéktakaró borítja. A mélyebb rétegek azonban 50-200 méteres mélységig jó víztározó folyóvízi iszapos-homokoskavicsból állnak (MAROSI \& SOMOGYI, 1990). Éghajlata mérsékelten hűvös és száraz. Klimatikus viszonyaira Mosonmagyaróvár Meteorológiai Állomás adatai alapján következtethetünk. Jellemző értékei a következők (FARAGÓ, 1989):

$\begin{array}{ll}\text { Évi közzéphőmérséklet } & 9,6{ }^{\circ} \mathrm{C} \\ \text { Relatív légnedvesség } & 73 \% \\ \text { Téli napok száma }\left(\max .=0{ }^{\circ} \mathrm{C}\right) & 29 \text { nap } \\ \text { Nyári napok száma }\left(\max .>25^{\circ} \mathrm{C}\right) & 62 \text { nap } \\ \text { Évi csapadék } & 504 \mathrm{~mm} \\ \text { Zord napok száma }\left(\min .<-10{ }^{\circ} \mathrm{C}\right) & 13 \text { nap } \\ \text { Fagyos napok száma }\left(\min .=0{ }^{\circ} \mathrm{C}\right) & 95 \text { nap } \\ \text { Hőségnapok száma }\left(\max .>30^{\circ} \mathrm{C}\right) & 12 \text { nap }\end{array}$

Csapadékeloszlására egy júniusi és egy októberi maximum jellemző. A főmaximum óceáni hatásra utal, míg az őszi másodmaximum a mediterrán hatás eredménye. A kontinentális klímahatást az 500 mm körüli csapadékösszeg bizonyítja.

Hidrológiai szempontból a vizsgálati terület vízszegénynek mondható. Vízfolyás nincs. Két kisebb tó van a területen, egyik a korábbi kavicsbányászat eredménye, míg a másik (Kápolnatanya), az öntözőfürt vízkivételi müvének vízszükségletét biztosító, talajvízből táplálkozó tó.

A területre a csernozjom talajok jellemzöek, melyek tulajdonságait a különbözö mélységben elhelyezkedő kavicsos réteg szabja meg. A talaj felső, $30 \mathrm{~cm}-$ es rétegéből vett talajminták elemzése során a következő tájékoztató értékek adódtak (13 minta alapján, FARAGÓ, 1989):

$\begin{array}{ll}\mathrm{pH}\left(\mathrm{H}_{2} 0\right) & 7,1-8,0 \\ \mathrm{~K}_{\mathrm{A}} & 35-50 \\ 5 \mathrm{~h} \text { kapilláris vízemelés } & 133-211 \\ \mathrm{y}_{1} & 0-5,2 \\ \mathrm{CaCO}_{3} \% & 0-4,9 \\ \text { Humusz \% } & 3,47-5,40(7,34)\end{array}$

A humusztartalom kettős értékei közül az alacsonyabb maximum mezőgazdasági területre, a magasabb erdősáv területére vonatkozik. A terület növényföldrajzilag a Pannóniai Flóratartomány Alföldi Flóravidékének Kisalföldi flórajárásába tartozik (PÉCSI, 1975). 
A LAJTA Project a Nyugat-Magyarországi Egyetem Vadgazdálkodási Intézete (korábban Erdészeti és Faipari Egyetem Vadgazdálkodási Tanszék, ill. Soproni Egyetem Vadgazdálkodási Intézet) által indított hosszú lejáratú, tartamos („longterm”) élőhelyvizsgálat, amely a területen élő vadfajok és intenzív agrárkörnyezetük közt fennálló kölcsönhatásokat, azok időbeni változásait vizsgálja (FARAGÓ \& BUDAI, 1998). Az 1989-ben indult kutatási program széles spektrumát kutatja az intenzív agrárkörnyezet, mint mezei élettér élővilágának, valamint egyéb környezeti tényezőinek, illetve ezek egymásra gyakorolt hatásának is. Igy MoCZ (1990) és KARAKAI (1999) a mezei őzállományt, KISS (1992) a gyomállományokat, mint a vad növényi eredetű táplálékát, BUDAY (1993) és DITTRICH (1999) a fácánállományt, a vele való gazdálkodást (tenyésztést és hasznosítást), míg NAGY (2002) a fürj és a galambfélék (Columbidae) állományait vizsgálta.

Az erdősávok madárállományaival foglalkozott JÁNOSKA (1995b, 1998, 1999), aki a kérdéskört napjainkig, több mint 15 éve kutatja a területen. Jelen dolgozat mind metodikáját, mind a vizsgálatok tárgyát tekintve szorosan kapcsolódik a fenti munkához, tekintve, hogy a ragadozómadarak táplálékbázisát képező kisemlősökkel foglalkozik, melyet több éven keresztül ugyanazokban az erdősávokban vizsgál.

FARAGÓ (1993, 1994, 1997b, 1997c, 1997d, 1998, 2000, 2001, 2002), valamint FARAGÓ \& BUDAI (1998) a LAJTA Project fogolyállományának részletes vizsgálatát végezte el, beleértve a környezeti tényezőket, az állomány dinamikáját és az élőhelyválasztást. A terület egyben a MAGYAR FOGOLYVÉDELMI PROGRAM legfontosabb mintaterülete, mely program a tenyésztés és az élőhelyjavítás megfelelő arányával igyekszik a fenntarthatóság feltételeit megteremteni és azt a vadgazdálkodás napi gyakorlatának szolgálatába állítani.

A vizsgálati terület nagysága 3100 ha. A legközelebbi település Mosonszolnok, földrajzi koordinátái a következők: 470 51' N, 170 12' E.

A terület kimondottan intenzív agrárkörnyezet, melyre jellemző, hogy rét-legelöterület gyakorlatilag hiányzik. Az a mintegy 70-135 ha legelö, ami változó helyen előfordult az évek során, telepített füves here volt. A szántóterületeken (2678-2768 ha) föként kalászosokat, kukoricát, kendert és repcét termesztenek. Egy-egy termesztési ciklusban mintegy 10-15 növénykultúra tenyészik. A táblanagyságok - 56 tábla méretei alapján - 20-105 ha közt változnak, az átlagos táblanagyság 52 ha, ami vadgazdálkodási szempontból - figyelembe véve az erdősávok jelenlétét is - igen kedvezőnek mondható. Nagyobb összefüggő erdőterület nincs, az erdészetileg üzemtervezett 54 erdőrészlet erdősávok formájában jelenik meg, összterületük mintegy 110 ha. Két kisebb erdőfolt 42,2 ha-t, az erdőtelepítések pedig 33,0 ha-t tesznek ki.

A Project területének szerkezetét a rendszerváltást követő kárpótlás alapvetően megváltoztatta. Az addig gazdasági egységként kezelt terület feldarabolódott és mindössze 56 \%-a maradt állami tulajdonban (FARAGÓ \& BUDAI, 1998).

\subsection{A vizsgált kisemlös habitatok jellemzése}

Terepi vizsgálataim során a csapdavonalakat 1992 és 1997 között a LAJTA Project erdősávjaiban, valamint a Mosonszolnok 3F jelü akác erdőfoltban állítottam fel. A vizsgált erdősávokra általánosan jellemző, hogy klasszikus módon, fő- és melléksávokként kerültek telepítésre, a rossz talajviszonyok miatt meglehetősen gyenge növekedésủek. Fö fafajaik az akác (Robinia pseudoacacia), valamint az amerikai kőris (Fraxinus americana). Mellettük nagyobb számban fordul elő még a magas kőris (Fraxinus excelsior), nemesnyárak (Populus $x$ euramericana hibridek), lepényfa (Gleditsia triacanthos), korai juhar (Acer platanoides), hegyi juhar (Acer pseudoplatanus), helyenként az ezüstjuhar (Acer saccharinum). A cserjeszintben jellemző fajok a fagyal (Ligustrum vulgare), a keskenylevelü ezüstfa (Eleagnos 
angustifolia), a kinincs (Amorpha fruticosa) és a gyepürózsa (Rosa canina). A gyepszint uralkodó lágyszárú fajai a ragadós galaj (Galium aparine), a cérnatippan (Agrestis tenuis), a fedél rozsnok (Bromus sterilis), a közönséges tarackbúza (Agropyron repens), valamint a csomós ebír (Dactylis glomerata).

Az 1999-ben alkalmazott kvadrát módszer során három, erdősáv és a szomszédos mezőgazdasági kultúrák alkotta élőhelykomplexet, valamint a Mosonszolnok 3F jelü akác erdőfoltot vizsgáltam, melyekről részletesebb cönológiai felvételezést készítettem. A 7 - 7 csapdából álló kvadrátok minden erdősávval párhuzamos -és éppen ezért homogénnek tekinthető növényzeti jellemzőkkel bíró- csapdasorában három mintavételi helyen felmértem a cserjeszint és a gyepszint jellemző fajait, a szintek össz-borítását és az egyes fajok A-D valamint magasság értékeit. Ezeket csapdasoronként átlagolva kaptam a csapdasorra jellemző értékeket. Az egyes kvadrátok és azok csapdasorainak jellemzői az alábbiak:

\section{F kvadrát}

A kvadrát a Mosonszolnok 3F akác erdőfoltban és a határán lévő Mosonszolnok 3K erdősávban került elhelyezésre.

Első csapdasora $(3 \mathrm{~F}-\mathrm{I})$ az erdősáv és a mellette húzódó mezei út szegélyében húzódott. A cserjeszint $50 \%-\mathrm{os}$ borítását kinincs $(\mathrm{A}-\mathrm{D}=50 \%)$ és fagyal $(\mathrm{A}-\mathrm{D}=50 \%)$ biztosította, a gyepszintben angol- $(\mathrm{A}-\mathrm{D}=70 \%)$, réti $(\mathrm{A}-\mathrm{D}=20 \%)$ és franciaperje $(\mathrm{A}-\mathrm{D}=5 \%)$, továbbá csomós ebír $(\mathrm{A}-\mathrm{D}=5 \%)$ fordult elö, mindösszesen $50 \%$-os borításban.

A második csapdasorban (3F-II) a kinincs (40\%), fagyal (40\%) és fekete bodza (20\%) cserjeszintje mindösszesen $40 \%$-os borítást biztosított, a gyepszintet $100 \%$-ban közönséges tarackbúza uralta, mely $40 \mathrm{~cm}$ magas volt átlagosan.

A harmadik csapdasor (3F-III) cserjeszintje már kifejezetten laza, 25\% borítást mutat a kinincs. A gyepszintben réti perjét (50\%), piros árvacsalánt (30\%) és fedél rozsnokot (20\%) mutattam ki.

A negyedik csapdasorban (3F-IV) a fekete bodza alkotta cserjeszint már csak 10\%-os borítást biztosított, a gyepszintet közönséges tarackbúza (50\%), fedél rozsnok (40\%) és piros árvacsalán $(10 \%)$ uralta.

Az ötödik csapdasorból $(3 \mathrm{~F}-\mathrm{V})$ a cserjeszint hiányzik, a gyepszintben fedél rozsnok (50\%), közönséges tarackbúza (20\%) és piros árvacsalán (30\%) található.

A hatodik csapdasorban $(3 \mathrm{~F}-\mathrm{VI})$ is hiányzik a cserjeszint, a gyepszintet fedél rozsnok (90\%) és közönséges tarackbúza (10\%) uralja.

A hetedik csapdasorból (3F-VII) a cserjeszint hiányzik, a gyepszintben piros árvacsalán (70\%) és fedél rozsnok (30\%) található.

\section{G kvadrát}

A kvadrát a Mosonszolnok 3G erdősávban, a vele szomszédos $22 / 2$ jelü tritikále és $22 / 3$ jelü őszi búza táblában került elhelyezésre.

Első és második csapdasora (3G-I, 3G-II) a 22/2 jelü táblában húzódott. A gyepszintben tritikále (100\%) fordult elö, 100\%-os borításban.

A harmadik csapdasor (3G-III) a tritikále és a szomszédos mezei út találkozásánál került felállításra. A gyepszintben tritikále (50\%), közönséges tarackbúza (25\%) és kamilla (25\%) fordult elö, mindösszesen $100 \%$-os borításban.

A negyedik csapdasorban (3G-IV) -mely a mezei út és a $3 \mathrm{G}$ erdősáv határán helyezkedett el- fagyal alkotott cserjeszintet, amely 30\%-os borítást biztosított. A gyepszintet 
5 növényfaj, az angolperje (40\%), a csomós ebír (15\%), a franciaperje (15\%), a réti perje $(15 \%)$ és a közönséges aszat (15\%) uralta.

Az ötödik csapdasor $(3 \mathrm{G}-\mathrm{V}), 3 \mathrm{G}$ erdősáv belsejében található, előzőnél sürübb cserjeszintjét szintén fagyal képezi, a gyepszintben közönséges aszat (50\%) dominál, mellette réti $(25 \%)$ és franciaperje (25\%) fordul elö.

A hatodik csapdasorban (3G-VI) is fagyal alkotja a cserjeszintet (40\%), a gyepszintet, közönséges aszat (40\%), réti (20\%) és franciaperje (40\%) uralja.

A hetedik csapdasorból (3G-VII), mely a $3 \mathrm{G}$ erdősáv és a $22 / 3$ jelü őszi búza tábla határán húzódik, a cserjeszint hiányzik. A gyepszintben öszi búza dominál (50\%), mellette csomós ebír (10\%), közönséges tarackbúza (10\%), franciaperje (10\%), réti perje (10\%) és közönséges aszat (10\%) található.

\section{A kvadrát}

A kvadrát a cserjeszint nélküli Mosonszolnok 4A erdősávban, a vele szomszédos 23/5 jelü takarmánylucerna-táblában, ill. a kettő közt elhelyezkedő gyomsávban került elhelyezésre.

Első csapdasora (4A-I) az erdősáv és a szomszédos mezei út határán húzódott. A gyepszintben réti- (60\%) angol- (20\%) és franciapeje (20\%) fordult elö, mindösszesen 100\%-os borításban.

Második csapdasora (4A-II) az erdősáv középvonalában helyezkedett el. A gyepszintben réti- $(60 \%)$ és franciapeje $(40 \%)$ fordult elö.

A harmadik csapdasor (4A-III) a gyomsáv és az erdősáv találkozásánál került felállításra. A gyepszintben közönséges tarackbúza (30\%), angolperje (30\%), közönséges aszat (10\%) és réti perje (30\%) fordult elö, mindösszesen $100 \%$-os borításban.

A negyedik csapdasorban (4A-IV) - mely a takarmánylucerna és a gyomsáv határán helyezkedett el-, a gyepszintet 3 növényfaj, a takarmánylucerna (40\%), az angolperje (40\%) és a betyárkóró $(20 \%)$ uralta.

Az ötödik, hatodik, hetedik csapdasor (4A-V, 4A-VI, 4A-VII) a takarmánylucerna belsejében található, a gyepszintben kizárólag ez a növény fordul elö.

\section{C kvadrát}

A kvadrát a Mosonszolnok 4C erdősávban, a vele szomszédos 23/3 jelü kukorica és 23/4 jelü tárcsázott borsótarló táblában -melynek erdősáv felöli szegélye vadföldként volt müvelvekerült elhelyezésre.

Első csapdasora (4C-I) a 23/4 jelü tárcsázott borsótarló táblában húzódott. A gyepszint ezért nudum volt.

Második csapdasora (4C-II) szintén a 23/4 jelü tárcsázott borsótarló táblában került elhelyezésre, itt azonban a gyepszint már 30\% borítást mutatott, melyet a betyárkóró (70\%) és a fehér libatop (30\%) megjelenése biztosított.

A harmadik csapdasor (4C-III) a vadföld sávjában került felállításra. A gyepszintben angolperje (40\%), közönséges tarackbúza (40\%), betyárkóró (15\%) és közönséges aszat (5\%) fordult elö, mindösszesen $100 \%$-os borításban.

A negyedik csapdasorban (4C-IV) -mely az erdősáv belsejében helyezkedett elfagyal alkotott cserjeszintet, amely 50\%-os borítást biztosított. A gyepszintet 2 növényfaj, a fedél rozsnok (70\%) és a közönséges tarackbúza (30\%) uralta.

Az ötödik csapdasor (4C-V) 4C erdősáv belsejében található, előzőnél sürübb cserjeszintjét szintén fagyal képezi (70\%), a gyepszintben fedél rozsnok (100\%) fordul elő. 
A hatodik csapdasorban (4C-VI) -az erdősáv és a kukoricatábla határán- nincs cserjeszint, a gyepszintet kukorica (50\%), közönséges aszat (20\%) és közönséges tarackbúza $(30 \%)$ uralja.

A hetedik csapdasor (4C-VII) a kukoricatábla területén húzódik, benne a kukoricán kívül más növény nem található.

A felvételeket 1999. első csapdázási periódusában, július elején készítettem. A következő csapdázások alkalmával a mezőgazdasági kultúrákban történő változásokat is rögzítettem, melyek az alábbiak voltak: a 4A kvadrátban a júliusban $15 \mathrm{~cm}$ magas lucernát augusztusra lekaszálták, majd szeptemberre ismét felnőtt $40 \mathrm{~cm}-\mathrm{re}$. A 3G kvadrátban az őszi búzát és a tritikálét augusztusra learatták. A 4C kvadrátban a borsótarlót szeptemberre 80\%ban $50 \mathrm{~cm}$ magas muhar borította, a kukoricatáblát learatták és felszántották, a 3. csapdasor gyepszintjét pedig lekaszálták.

\section{EREDMÉNYEK}

Elsőként a kisemlős populációk jellemzése során a területről általam kimutatott fajok populációs ismérveit foglalom össze, így tárgyalom fajonként a diszperzió, biometria, mikrohabitat használat, ivararány, dinamika és testtömeg változás kérdéseit. Ezt követően tekintem át az egyes erdősávokban fogott kisemlősök által alkotott közösségeket, azok elsődleges és származtatott karakterisztikáit, összefüggésüket az élőhelyszerkezettel, továbbá a szegélyhatás és izoláció kérdéskörét, az erdősáv-rendszer, mint zöld folyosó szerepét a kisemlős-metapopulációk fenntartásában.

A vizsgált 24 erdősávban 11202 csapdaéjszakán 11, talajlakó, -rovarevő és rágcsálókisemlős faj 1645 egyedének jelenlétét sikerült kimutatni (6. ábra). A terület domináns kisemlős faja a közönséges erdeiegér. A szubdomináns fajok közül a nyílt területekre jellemző mezei pocok a leggyakoribb, de jelentős -összesen 30,7 \%-a lomberdőkre jellemző vöröshátú erdeipocok és a sárganyakú erdeiegér előfordulása is. A ritka fajok közt az erdei és a hozzá hasonló élőhelyeken előforduló törpecickány Sorex minutus LiNNAEUS, 1766 a leggyakoribb, a földipocok Pitymys subterraneus (DE SÉLYS LONGCHAMPS, 1836) pedig, egy példány elöfordulásával a legritkább.

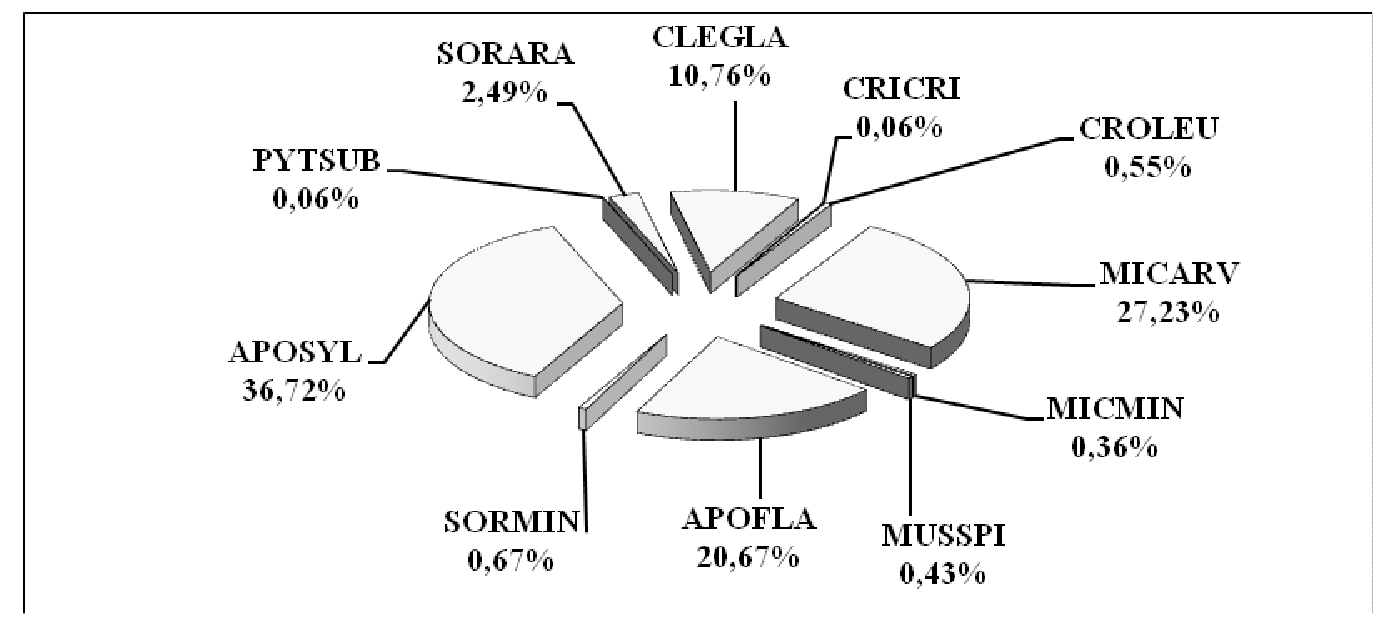

\section{1. ábra: A LAJTA Projectben végzett kisemlős csapdázások fajösszetétele (1992-1999, $\mathrm{n}=\mathbf{1 6 4 5}$ )}

Figure 6: Dominance of small mammal species captured in the LAJTA Project (1992-1999, n=1645)

Az egyes évek erdősávonkénti fogási eredményeit a 2. táblázat mutatja. 
2. táblázat: Az egyes évek erdősávonkénti fogási eredményei a LAJTA-Projectben

Table 2: Yearly capturing data of the different forest belts in the LAJTA-Project

\begin{tabular}{|c|c|c|c|c|c|c|c|c|c|c|c|c|c|c|c|c|c|c|c|c|c|c|c|c|}
\hline & \multicolumn{2}{|c|}{ APOFLA } & \multicolumn{2}{|c|}{ APOSYL } & \multicolumn{2}{|c|}{ CLEGLA } & \multicolumn{2}{|c|}{ CROLEU } & \multicolumn{2}{|c|}{ MICARV } & \multicolumn{2}{|c|}{ SORARA } & \multicolumn{2}{|c|}{ SORMIN } & \multicolumn{2}{|c|}{ MICMIN } & \multicolumn{2}{|c|}{ CRICRI } & \multicolumn{2}{|c|}{ MUSSPI } & \multicolumn{2}{|c|}{ PYTSUB } & \multicolumn{2}{|c|}{ Összesen } \\
\hline & pld & $\%$ & pld & $\%$ & pld & $\%$ & pld & $\%$ & pld & $\%$ & pld & $\%$ & pld & $\%$ & pld & $\%$ & pld & $\%$ & pld & $\%$ & pld & $\%$ & pld & $\%$ \\
\hline \multicolumn{25}{|c|}{1992} \\
\hline $3 \mathrm{~F}$ & 18 & 28,13 & 5 & 7,81 & 36 & 56,25 & 2 & 3,13 & 3 & 4,69 & 0 & 0,00 & 0 & 0,00 & 0 & 0,00 & 0 & 0,00 & 0 & 0,00 & 0 & 00 & 64 & $\overline{100}$ \\
\hline $3 G$ & 2 & 3,92 & 0 & 0,00 & 25 & 49,02 & 0 & 0,00 & 18 & 35,29 & 6 & 11,76 & 0 & & $\sigma_{-}$ & 00 & 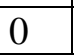 & 00 & & 00 & 0 & 00 & 51 & 100 \\
\hline $3 \mathrm{H}$ & 11 & 20,75 & 12 & 22,64 & 4 & 7,55 & 0 & 00 & 24 & 45,28 & 2 & 3,77 & 0 & & 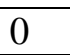 & 00 & 0 & 00 & & 00 & 0 & 00 & 53 & $\overline{100}$ \\
\hline $3 \mathrm{I}$ & 15 & 1,74 & 19 & 27,54 & 21 & 30,43 & 2 & 2,90 & 10 & 12 & 1 & 1,45 & 0 & 00 & & 45 & 0 & 00 & 0 & 00 & 0 & 00 & 69 & $\overline{100}$ \\
\hline $4 \mathrm{~A}$ & 3 & 33,33 & 0 & 0,00 & 1 & 11,11 & 0 & 0,00 & 5 & 55,56 & 0 & 0,00 & 0 & 0,00 & 0 & 00 & 0 & 00 & 0 & 00 & 0 & 00 & 9 & 100 \\
\hline $4 \mathrm{C}$ & 12 & 18 & 7 & 10,77 & 20 & 30,77 & 0 & 0,00 & 25 & 38,46 & 1 & 1,54 & 0 & 0,00 & O & 0,00 & 0 & 0,00 & 0 & 0,00 & 0 & 00 & 65 & 100 \\
\hline $68 \mathrm{C}$ & 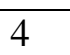 & 21,05 & 2 & 10,53 & 1 & 5,26 & 4 & 21,05 & 8 & 42,11 & 0 & 0,00 & 0 & 0,00 & 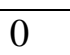 & 0,00 & 0 & 0,00 & 0 & 0,00 & 0 & 0,00 & 19 & 100 \\
\hline 68D & 12 & 57,14 & 4 & 19,05 & 2 & 9,52 & 0 & 0,00 & 2 & 9,52 & 1 & 4,76 & 0 & 0,00 & 0 & 0,00 & 0 & 0,00 & 0 & 0,00 & 0 & 0,00 & 21 & 100 \\
\hline $69 \mathrm{~B}$ & & 20,83 & 5 & 20,83 & 4 & 16,67 & 0 & 0,00 & 9 & 37,50 & 1 & 4,17 & 0 & 0,00 & 0 & 0,00 & 0 & 0,00 & 0 & 0,00 & 0 & 0,00 & 24 & 100 \\
\hline $69 \mathrm{C}$ & 5 & 71 & 4 & 57 & 0 & 0,00 & 0 & 0,00 & 5 & 35,71 & 0 & 0,00 & 0 & 0,00 & 0 & 0,00 & 0 & 0,00 & 0 & 0,00 & 0 & 0,00 & 14 & 100 \\
\hline $69 \mathrm{E}$ & 4 & 17,39 & 4 & 17,39 & 1 & 4,35 & 0 & 0,00 & 13 & 56,52 & 1 & 4,35 & 0 & 0,00 & 0 & 0,00 & 0 & 0,00 & 0 & 0,00 & 0 & 0,00 & 23 & 100 \\
\hline $69 \mathrm{~F}$ & 6 & 18,18 & 2 & 6,06 & 12 & 36,36 & 0 & 0,00 & 5 & 15,15 & 6 & 18,18 & 2 & 6,06 & 0 & 0,00 & 0 & 0,00 & 0 & 0,00 & 0 & 0,00 & 33 & 100 \\
\hline $70 \mathrm{~A}$ & 4 & 20,00 & 1 & 5,00 & 0 & 0,00 & 0 & 0,00 & 14 & 70,00 & 1 & 5,00 & 0 & 0,00 & 0 & 0,00 & 0 & 0,00 & 0 & 0,00 & 0 & 0,00 & 20 & $\overline{100}$ \\
\hline $70 B$ & 15 & 44,12 & 7 & 20,59 & 0 & 0,00 & 0 & 0,00 & 11 & 32,35 & 1 & 2,94 & 0 & 0,00 & 0 & 0,00 & 0 & 0,00 & 0 & 0,00 & 0 & 0,00 & 34 & 100 \\
\hline $70 \mathrm{C}$ & 10 & 27,78 & 6 & 16,67 & 1 & 2,78 & 0 & 0,00 & 15 & 41,67 & 3 & 8,33 & 9 & 2,78 & 0 & 0,00 & 0 & 0,00 & 0 & 0,00 & 0 & 0,00 & 36 & 100 \\
\hline $70 \mathrm{D}$ & 17 & 60,71 & 4 & 14,29 & 3 & 10,71 & 0 & 0,00 & 3 & 10,71 & 1 & 3,57 & 0 & 0,00 & 0 & 0,00 & 0 & 0,00 & 0 & 0,00 & 0 & 0,00 & 28 & $\overline{100}$ \\
\hline \multicolumn{25}{|c|}{1993} \\
\hline $3 \mathrm{~B}$ & 4 & 80,00 & 1 & 20,00 & 0 & 0,00 & 0 & 0,00 & 0 & 0,00 & 0 & 0,00 & 0 & 0,00 & 0 & 0,00 & 0 & 0,00 & 0 & 0,00 & 0 & 0,00 & 5 & 100 \\
\hline $3 \mathrm{C}$ & 4 & 80,00 & 1 & 20,00 & 0 & 0,00 & 0 & 0,00 & 0 & 0,00 & 0 & 0,00 & 0 & 0,00 & 0 & 0,00 & 0 & 0,00 & 0 & 0,00 & 0 & 0,00 & 5 & 100 \\
\hline $3 \mathrm{D}$ & 2 & 50,00 & 2 & 50,00 & 0 & 0,00 & 0 & 0,00 & 0 & 0,00 & 0 & 0,00 & 0 & 0,00 & 0 & 0,00 & 0 & 0,00 & 0 & 0,00 & 0 & 0,00 & 4 & 100 \\
\hline $3 \mathrm{E}$ & 5 & 83,33 & 1 & 16,67 & 0 & 0,00 & 0 & 0,00 & 0 & 0,00 & 0 & 0,00 & 0 & 0,00 & 0 & 0,00 & 0 & 0,00 & 0 & 0,00 & 0 & 0,00 & 6 & 100 \\
\hline $3 \mathrm{~F}$ & 1 & 100,00 & 0 & 0,00 & 0 & 0,00 & 0 & 0,00 & 0 & 0,00 & 0 & 0,00 & 0 & 0,00 & 0 & 0,00 & 0 & 0,00 & 0 & 0,00 & 0 & 0,00 & 1 & 100 \\
\hline $4 \mathrm{D}$ & 1 & 33,33 & 1 & 33,33 & 0 & 0,00 & 0 & 0,00 & 1 & 33,33 & 0 & 0,00 & 0 & 0,00 & 0 & 0,00 & 0 & 0,00 & 0 & 0,00 & 0 & 0,00 & 3 & 100 \\
\hline $4 \mathrm{E}$ & 4 & 66,67 & 1 & 16,67 & 1 & 16,67 & 0 & 0,00 & 0 & 0,00 & 0 & 0,00 & 0 & 0,00 & 0 & 0,00 & 0 & 0,00 & 0 & 0,00 & 0 & 0,00 & 6 & 100 \\
\hline
\end{tabular}


2. táblázat (folytatás): Az egyes évek erdősávonkénti fogási eredményei a LAJTA-

\section{Projectben}

Table 2 (continuing): Yearly capturing data of the the different forest belts in the LAJTA-Project

\begin{tabular}{|c|c|c|c|c|c|c|c|c|c|c|c|c|c|c|c|c|c|c|c|c|c|c|c|c|}
\hline & \multicolumn{2}{|c|}{ APOFLA } & \multicolumn{2}{|c|}{ APOSYL } & \multicolumn{2}{|c|}{ CLEGLA } & \multicolumn{2}{|c|}{ CROLEU } & \multicolumn{2}{|c|}{ MICARV } & \multicolumn{2}{|c|}{ SORARA } & \multicolumn{2}{|c|}{ SORMIN } & \multicolumn{2}{|c|}{ MICMIN } & \multicolumn{2}{|c|}{ CRICRI } & \multicolumn{2}{|c|}{ MUSSPI } & \multicolumn{2}{|c|}{ PYTSUB } & \multicolumn{2}{|c|}{ Összesen } \\
\hline & pld & $\%$ & pld & $\%$ & pld & $\%$ & pld & $\%$ & pld & $\%$ & pld & $\%$ & pld & $\%$ & pld & $\%$ & pld & $\%$ & pld & $\%$ & pld & $\%$ & pld & $\%$ \\
\hline \multicolumn{25}{|c|}{1994} \\
\hline $3 \mathrm{~F}$ & 4 & 16,67 & 16 & 67 & 1 & 4,17 & 0 & 0,00 & 3 &, 50 & 0 & 0,00 & 0 & 00 & 0 & 00 & 0 & 00 & 0 & 00 & 0 & 0,00 & 24 & 100 \\
\hline $3 \mathrm{G}$ & 1 & 7,14 & 2 & 14,29 & 1 & 7,14 & 0 & 0,00 & 7 & 50,00 & 0 & 0,00 & 1 & 7,14 & 2 & 29 & 0 & 00 & 0 & 00 & 0 & 00 & 14 & 00 \\
\hline $3 \mathrm{H}$ & 3 & 9,68 & 3 & 9,68 & 1 & 3,23 & 0 & 0,00 & 21 & 67,74 & 3 & 58 & 0 & 0,00 & | & 0,00 & 0 & 00 & 0 & 00 & 0 & 00 & 31 & 00 \\
\hline $3 \mathrm{I}$ & 2 & 10,00 & 4 & 20,00 & 4 & 20,00 & 0 & 0,00 & 10 & 50,00 & 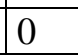 & 0,00 & 0 & 0 & 0 & 0 & ( & 00 & 0 & 00 & 0 & 00 & 20 & 00 \\
\hline $4 \mathrm{~A}$ & 1 & 10,00 & 4 & 40,00 & 1 & 10 & 0 & 0 , & 3 & 30 & 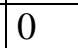 & 0,00 & 1 & 00 & 0 & 0 & 0 & 00 & 0 & 00 & 0 & 00 & 10 & 00 \\
\hline $4 C$ & 2 & 7,41 & 12 & 44,44 & 4 & 14,81 & 1 & 3,70 & 8 & 29,63 & 0 & 0,00 & 0 & 0,00 & 0 & 0 & 0 & 00 & 0 & 00 & 0 &, 00 & 27 & 100 \\
\hline $4 \mathrm{G}$ & 0 & 0,00 & 3 & 42,86 & 0 & 0,00 & 0 & 0,00 & 3 & 42,86 & 0 & 0,00 & 0 & 0,00 & 0 & 0,00 & 1 & 14,29 & 0 & 0,00 & 0 & 0,00 & 7 & 100 \\
\hline $68 \mathrm{C}$ & 2 & 33,33 & 3 & 50,00 & 1 & 16,67 & 0 & 0,00 & 0 & 0,00 & 0 & 0,00 & 0 & 0,00 & 0 & 0,00 & 0 & 0,00 & 0 & 0,00 & 0 & 0,00 & 6 & 100 \\
\hline 68D & 6 & 75,00 & 1 & 12,50 & 1 & 12,50 & 0 & 0,00 & 0 & 0,00 & 0 & 0,00 & 0 & 0,00 & 0 & 0,00 & 0 & 0,00 & 0 & 0,00 & 0 & 0,00 & 8 & 100 \\
\hline $69 \mathrm{~B}$ & 8 & 61,54 & 4 & 30,77 & 0 & 0,00 & 0 & 0,00 & 1 & 7,69 & 10 & 0,00 & 0 & 0,00 & 0 & 0,00 & 0 & 0,00 & 0 & 0,00 & 0 & 0,00 & 13 & 100 \\
\hline $69 \mathrm{C}$ & 4 & 33,33 & 7 & 58,33 & 0 & 0,00 & 0 & 0,00 & 1 & 8,33 & 0 & 0,00 & 0 & 0,00 & 0 & 0,00 & 0 & 0,00 & 0 & 0,00 & 0 & 0,00 & 12 & 100 \\
\hline $69 \mathrm{E}$ & 2 & 9,52 & 11 & 52,38 & 1 & 4,76 & 0 & 0,00 & 7 & 33,33 & 0 & 0,00 & 0 & 0,00 & 0 & 0,00 & 0 & 0,00 & 0 & 0,00 & 0 & 0,00 & 21 & 100 \\
\hline $69 \mathrm{~F}$ & 6 & 28,57 & 8 & & 0 & & 0 & & 7 & & 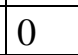 & & 0 & & & & 0 & & . & 0,00 & 0 & 0,00 & 21 & 100 \\
\hline $70 \mathrm{~A}$ & 1 & 7,69 & 6 & & 2 & & 0 & & 3 & & 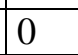 & & 1 & 1, & 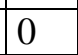 & & 0 & & 0 & 00 & 0 & 0 & 13 & 100 \\
\hline $70 B$ & 2 & 16,67 & 5 & 41,67 & 2 & 16,67 & 0 & 0, & ( & & 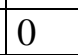 & & 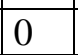 & & 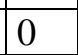 & & 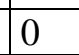 & & 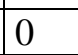 & 0 & 0 & 0,00 & 12 & 100 \\
\hline \multicolumn{25}{|c|}{1996} \\
\hline $3 \mathrm{E}$ & 1 & 50,00 & 0 & 0,00 & 0 & 0,00 & 0 & 0,0 & 11 & 50,00 & 10 & 00 & 0 & 0,0 & 10 & 0,00 & 0 & 10 & 0 & 0,00 & 0 & 0,00 & 2 & 100 \\
\hline $3 \mathrm{G}$ & 0 & 0,00 & 5 & 83,33 & 0 & 0,00 & 0 & 0,00 & 1 & 16,67 & 0 & 0,00 & 0 & 0,00 & 0 & 0,00 & 0 & 0,00 & 0 & 0,00 & 0 & 0,00 & 6 & 100 \\
\hline $3 \mathrm{H}$ & 2 & 28,57 & 1 & 14,29 & 0 & 0,00 & 0 & 0,00 & 4 & 57,14 & 0 & 0,00 & 0 & 0,00 & 0 & 0,00 & 0 & 0,00 & 0 & 0,00 & 0 & 0,00 & 7 & 100 \\
\hline $3 I$ & 2 & 20,00 & 5 & 50,00 & 3 & 30,00 & 0 & 0,00 & 0 & 0,00 & 0 & 0,00 & 0 & 0,00 & 0 & 0,00 & 0 & 0,00 & 0 & 0,00 & 0 & 0,00 & 10 & 100 \\
\hline $4 \mathrm{~A}$ & 0 & 0,00 & 1 & 100,00 & 0 & 0,00 & 0 & 0,00 & 0 & 0,00 & 0 & 0,00 & 0 & 0,00 & 0 & 0,00 & 0 & 0,00 & 0 & 0,00 & 0 & 0,00 & 1 & 100 \\
\hline $4 \mathrm{~B}$ & 0 & 0,00 & 0 & 0,00 & 0 & 0,00 & 0 & 0,00 & 4 & 100,00 & 0 & 0,00 & 0 & 0,00 & 0 & 0,00 & 0 & 0,00 & 0 & 0,00 & 0 & 0,00 & 4 & 100 \\
\hline $4 \mathrm{C}$ & 1 & 20,00 & 2 & 40,00 & 1 & 20,00 & 0 & 0,00 & 1 & 20,00 & 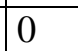 & 0,00 & 0 & 0,00 & 0 & 0,00 & 0 & 0,00 & 0 & 0,00 & 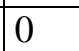 & 0,00 & 5 & 100 \\
\hline
\end{tabular}


2. táblázat (folytatás): Az egyes évek erdősávonkénti fogási eredményei a LAJTA-

\section{Projectben}

Table 2 (continuing): Yearly capturing data of the the different forest belts in the LAJTA-Project

\begin{tabular}{|c|c|c|c|c|c|c|c|c|c|c|c|c|c|c|c|c|c|c|c|c|c|c|c|c|}
\hline & \multicolumn{2}{|c|}{ APOFLA } & \multicolumn{2}{|c|}{ APOSYL } & \multicolumn{2}{|c|}{ CLEGLA } & \multicolumn{2}{|c|}{ CROLEU } & \multicolumn{2}{|c|}{ MICARV } & \multicolumn{2}{|c|}{ SORARA } & \multicolumn{2}{|c|}{ SORMIN } & \multicolumn{2}{|c|}{ MICMIN } & \multicolumn{2}{|c|}{ CRICRI } & \multicolumn{2}{|c|}{ MUSSPI } & \multicolumn{2}{|c|}{ PYTSUB } & \multicolumn{2}{|c|}{ Összesen } \\
\hline & pld & $\%$ & pld & $\%$ & pld & $\%$ & pld & $\%$ & pld & $\%$ & pld & $\%$ & pld & $\%$ & pld & $\%$ & & $\%$ & pld & $\%$ & pld & $\%$ & pld & $\%$ \\
\hline \multicolumn{25}{|l|}{1997} \\
\hline $3 \mathrm{~F}$ & 23 & 7,70 & & 57,38 & 0 & $\overline{00}$ & 0 & 00 & 3 & 92 & 0 & & 0 & 00 & &, 00 & T & 0,00 & 0 & 00 & 0 & 0,00 & 61 & 100 \\
\hline $3 G$ & 0 & 0,00 & $\varepsilon$ & 00 & 0 & 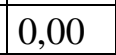 & 0 & 0 & 11 & & & & & 0 & & 00 & ( & 0,00 & 0 & 00 & & 0,00 & 0 & 100 \\
\hline $3 \mathrm{H}$ & 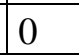 & & 1 & & 0 & & 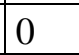 & & & & ( & & & & & & & & 0 & & & & & - \\
\hline $3 I$ & 3 & & & & 9 & & 0 & & 9 & & ( & & & & & 00 & & 00 & 0 & 00 & 0 & & 41 & $\overline{00}$ \\
\hline $4 \mathrm{~A}$ & 2 & & 1 & & 0 & & 0 & & 10 & & & & & & & & 0 & 00 & 1 & 35 & 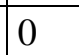 & & 6 & 100 \\
\hline $4 \mathrm{C}$ & 0 & 0,00 & 7 & & 1 & & . & 0 & 22 & & ( & & & & & 00 & O & 0,00 & 1 & 23 & ( & & & 100 \\
\hline $68 \mathrm{C}$ & 5 & 0 & 2 & 39 & 2 & 5,5 & 0 & 0 & 6 & 57 & 0 & & & & & 00 & ( & 0,00 & 0 & 00 & 0 & & & 100 \\
\hline $3 \mathrm{D}$ & 2 & & 5 & & 0 & & . & & 15 & & 1 & & & & & & 0 & & 0 & & 0 & & & \\
\hline $\mathrm{B}$ & 3 & & & & 0 & & 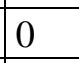 & & . & & & & & & & 0 & & 0 & 0 & & & & & 0 \\
\hline $69 \mathrm{C}$ & 2 & 8 & & 08 & 1 & 7,6 & 0 & 0 & 6 & 5 & 0 & & & 00 & $t$ & 00 & ( & 00 & 0 & 00 & 1 & 69 & 3 & 100 \\
\hline $69 \mathrm{E}$ & , & 00 & 1 & 33,33 & 0 & & 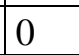 & 00 & 19 & & 1 & & & 0,00 & 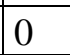 & 00 & 0 & 0,00 & 0 & 00 & 0 & 00 & 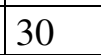 & 100 \\
\hline $69 \mathrm{~F}$ & 2 & $7 \mathrm{co}$ & 1 & 69,23 & 0 & & . & & 5 & 19,23 & 0 & & & & , & 00 & 0 & 0,00 & 1 & 85 & 0 & 0,00 & & 100 \\
\hline $70 A$ & 1 & & 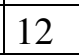 & & 0 & & . & & 10 & & 0 & & & & & & & & 1 & & & & & \\
\hline $70 B$ & | & & 1 & & 0 & & $y^{-1}$ & & 0 & & ( & & & & ( & & 0 & & 0 & & 0 & & & 100 \\
\hline $70 \mathrm{D}$ & 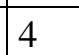 & & 1 & 5 & 1 & & . & & 5 & 1 & 1 & & & & 0 & 0 & 0 & 0,00 & 0 & & 0 & 0 & & 100 \\
\hline \multicolumn{25}{|l|}{1999} \\
\hline $3 \mathrm{~F}$ & 5 & 51 & 3 & 39,13 & 2 & & 0 & & 1 & & 0 & & & & $U_{0}$ & 0,00 & 0 & 0,00 & 0 & 00 & 0 & 0,00 & 2 & 100 \\
\hline $3 \mathrm{G}$ & 15 & 17,24 & 4 & 50,57 & 6 & & 工 & 00 & 13 & 14,94 & 4 & & & & 2 & 2,30 & 0 & 0,00 & 2 & 0 & 0 & 0,00 & 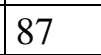 & 100 \\
\hline $4 \mathrm{~A}$ & 3 & & 5 & & 0 & & 0 & & 9 & & 2 & & $1=2$ & & 0 & & 0 & 00 & 0 & & 0 & & 71 & 100 \\
\hline $4 \mathrm{C}$ & 8 & 8,79 & 6 & 70,33 & 0 & & 0 & & 17 & 18,68 & 1 & & 10 & & 0 & 0,00 & 0 & 0,00 & 1 & & 0 & 0,00 & 1 & 100 \\
\hline Össz. & 340 & 20,67 & 604 & 36,72 & 177 & 10,76 & 9 & 0,55 & 448 & 27,23 & 41 & 2,49 & 11 & 0,67 & 6 & 0,36 & 1 & 0,06 & 7 & 0,43 & 1 & 0,06 & 1645 & 100 \\
\hline
\end{tabular}




\section{1. A kisemlős populációk jellemzői}

4. 1. 1. Erdei cickány - Sorex araneus LINNEAUS, 1758

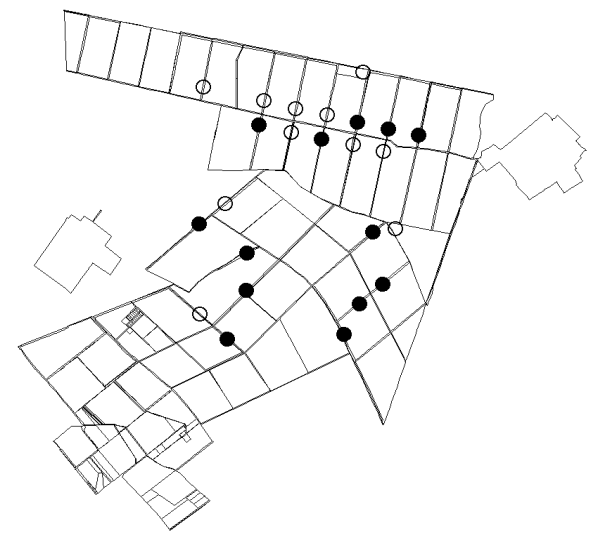

\section{7. térkép: Az erdei cickány előfordulása a LAJTA Projectben}

Map 8: The locations of the Common Shrew in the LAJTAProject

Palearktikus elterjedésű faj, amely Európában Írországból, a Hebridákról, Shetlandról, Franciaország és az Ibériai-félsziget nagy részéről hiányzik. A Mediterráneumban, beleértve a Balkán-félsziget déli részét és a földközi-tengeri szigeteket, szintén nem fordul elő (MitchelL-JONES et al., 1999). Földrajzi változatossága jelentős, Európában 19 alfaja ismert (MitchelL-JONES et al., 1999). Az erdei cickány biometriai jellemzőit a 3. táblázat tartalmazza.

\section{3. táblázat: Az erdei cickány biometriai jellemzői}

Table 3: Biometric features of the Common Shrew

\begin{tabular}{|l|c|c|c|c|c|}
\hline \multicolumn{1}{|c|}{$\begin{array}{c}\text { Testméretek } \\
\begin{array}{c}\text { Measurements } \\
\mathrm{n}=28\end{array}\end{array}$} & $\begin{array}{c}\text { Átlag } \\
\text { Mean }\end{array}$ & Min-max & $\begin{array}{c}\text { CORBET \& } \\
\text { OvENDEN, 1982 }\end{array}$ & $\begin{array}{c}\text { Szórás } \\
\text { Variance }\end{array}$ & $\begin{array}{c}\text { Konfidencia } \\
\text { intervallum } \\
\text { Confidence interval } \\
(\alpha=0,05)\end{array}$ \\
\hline Testtömeg $(\mathrm{g})-$ Weight & 5,3 & $1,5-8,0$ & $5,5-14$ & 1,54 & $5,3 \pm 0,63$ \\
\hline $\begin{array}{l}\text { Testhossz }(\mathrm{mm}) \\
\text { Body length }\end{array}$ & 68,7 & $58,0-79,0$ & $55-85$ & 6,16 & $68,7 \pm 2,52$ \\
\hline $\begin{array}{l}\text { Farokhossz }(\mathrm{mm}) \\
\text { Tail length }\end{array}$ & 41,4 & $37,0-46,0$ & $34-50$ & 2,75 & $41,4 \pm 1,10$ \\
\hline $\begin{array}{l}\text { Hátsó talp hossza }(\mathrm{mm}) \\
\text { Hind foot length }\end{array}$ & 13 & $8,0-18,0$ & $12-14,5$ & 2,17 & $13,0 \pm 0,87$ \\
\hline
\end{tabular}

Az erdei cickány a vizsgált 24 erdősávból 13-ban (54\%) fordult elő (8. térkép). Az 1999-ben végzett mikrohabitat vizsgálat alapján a faj fogott egyedeinek $42 \%$-a a $3 \mathrm{G}$ erdősáv IV. növényzeti egységéből került elő (7. ábra). Tekintve, hogy rovarevő fajról van szó a mikrohabitat választást -táplálkozási szempontból- a növényzet összetétele csak közvetve határozza meg. Nagyobb jelentőséggel bír a használt mikrohabitat helyzete. Ezt támasztja alá, hogy az erdei cickány által használt mikrohabitatok 70\%-ban szegély helyzetüek (erdősáv széle-mezei út széle, erdősáv széle-vadföld széle), amely szegélyeken a cickányok táplálékát képező rovarfajok -a szegélyhatás miatt- nagyobb denzitásban fordulnak elö. 


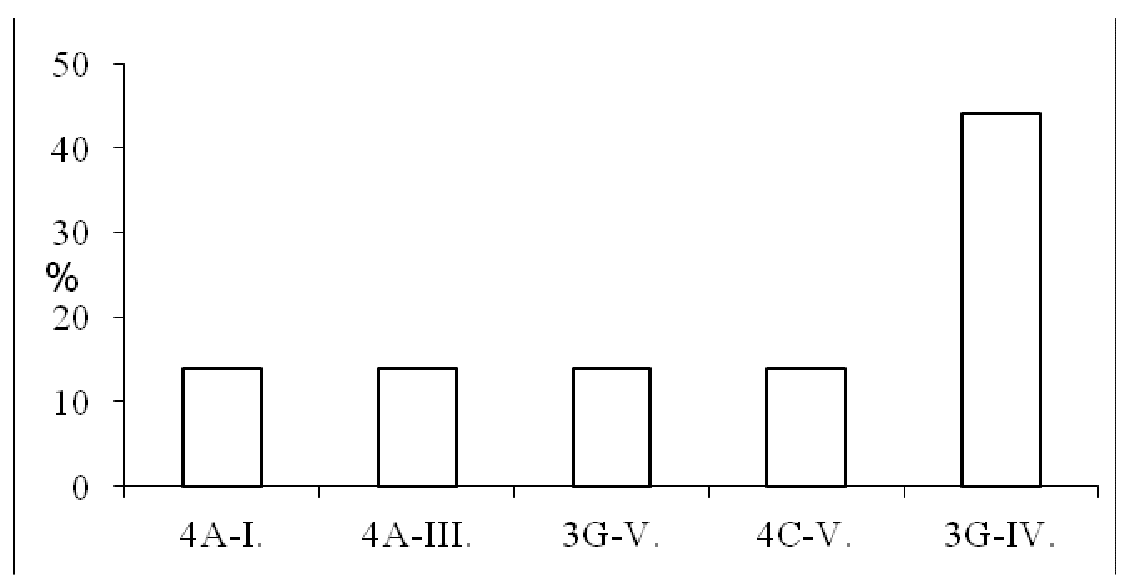

2. ábra: Az erdei cickány mikrohabitat használata $(n=7)$

Figure 7: Microhabitat use of the Common Shrew $(n=7)$

A faj egyedei az összes csapdázott kisemlös (n=1645) 2,5\%-át tették ki. A fogott 41 példányból 28-nak (68\%) sikerült meghatározni az ivarát, közülük 7\% nősténynek (20 pd), $29 \%$ hímnek (8 pd) bizonyult.

Az egy vegetációs perióduson belüli dinamika vizsgálatától az alacsony fogásszám miatt eltekintettem. Az évek közötti dinamika tekintetében, négy erdősáv közül, melyeket öt éven keresztül vizsgáltam, a 3F jelüben egyáltalán nem fordult elő a faj. Legnagyobb sűrüségben a 3G erdősávban fogtam 1992-ben, míg 1994-ben és 1996-ban egyáltalán nem csapdáztam (8. ábra).

A faj esetében kapott alacsony fogásszám értékek miatt nem végeztem szignifikancia vizsgálatot sem a különböző habitatok évenkénti, sem a különböző évek habitatonkénti fogásszámainak összehasonlítására.

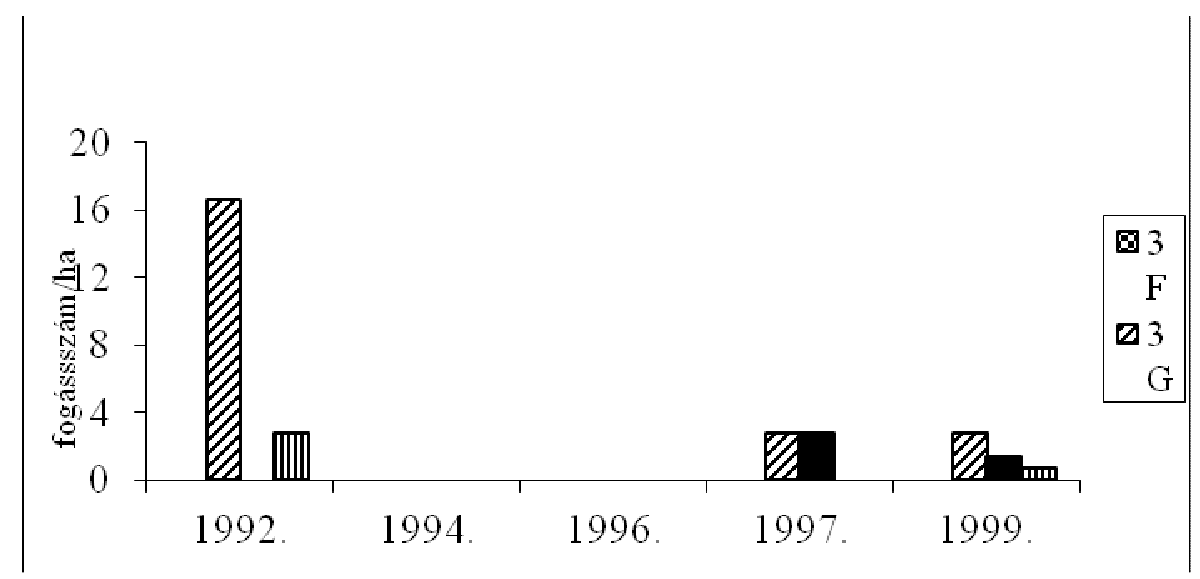

3. ábra: Az erdei cickány dinamikája a LAJTA Projectben

Figure 8: Dinamics of the Common Shrew in the LAJTA Project

Átlagos testtömeg alapján a legmagasabb értéket 1997-ben kaptam 7,0 grammal, a legalacsonyabb pedig az 1992. évi testtömeg (5,2 g) (9. ábra). Szignifikancia vizsgálatra a kis elemszám miatt itt sem kerülhetett sor. 


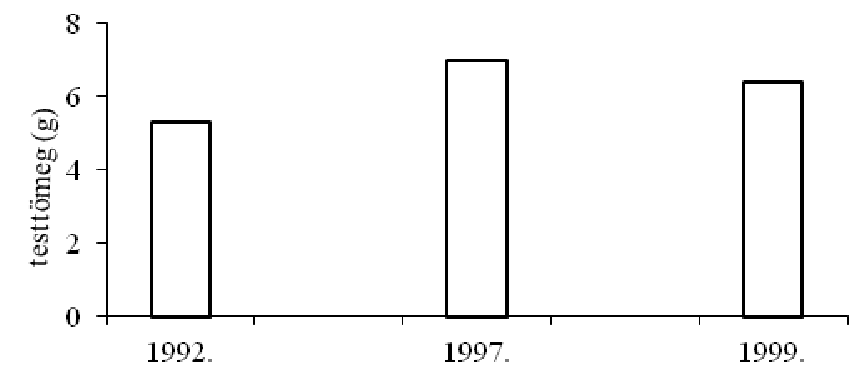

4. ábra: Az erdei cickány átlagos testtömegének változása a LAJTA Projectben $(n=31)$

Figure 9: Average weight changes of the Common Shrew in the LAJTA Project $(\mathrm{n}=31)$

\subsubsection{Törpecickány - Sorex minutus LINNAEUS, 1766}

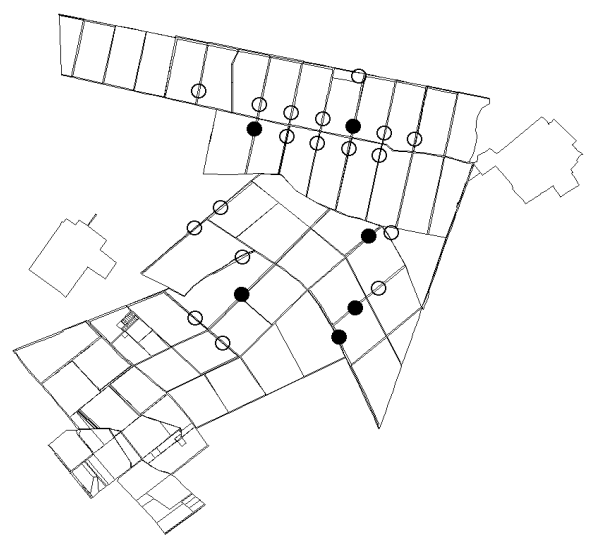

\section{8. térkép: A törpecickány előfordulása a LAJTA Projectben}

Map 9: Locations of the Eurasian Pygmy Shrew in the LAJTA Project

Eurázsiai elterjedésü, Európában csak az Ibériai-félsziget déli részéről, a mediterrán partvidékről és szigetekről, valamint a Skóciától északra fekvő szigetekről hiányzik (MitchelL-JONES et al., 1999). Földrajzi változatosságára jellemző, hogy északról dél felé a populációk testmérete szemmel láthatóan változik (MITCHELL-JONES et al.,, 1999). Biometriai jellemzőinek elemzésétől az alacsony fogásszám miatt eltekintettem.

A törpecickány a vizsgált 24 erdősávból 6-ban (25\%) fordult elő (9. térkép). A faj egyedei az összes csapdázott kisemlős $(\mathrm{n}=1645)$ 0,7\%-át tették ki. A fogott 11 példányból 3nak $(27 \%)$ sikerült meghatározni az ivarát, amely egyedek nősténynek bizonyultak. 


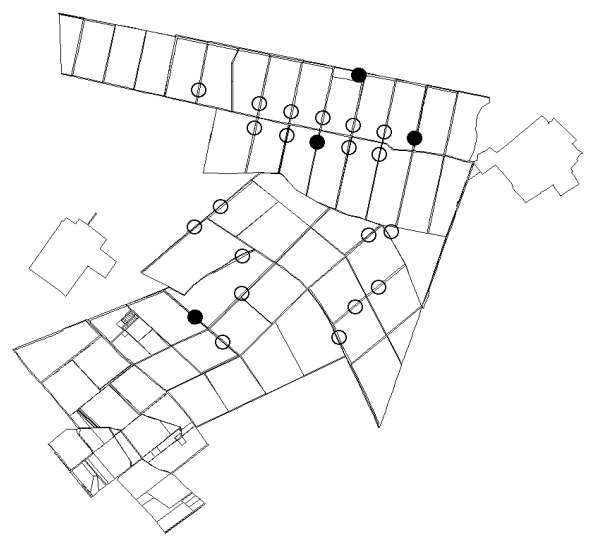

\section{9. térkép: A mezei cickány előfordulása a LAJTA Projectben \\ Map 10: Locations of the Bicolored Shrew in the LAJTA Project}

Európai és nyugat-ázsiai elterjedésű faj, mely Franciaország északnyugati részétől a Kaszpi-tengerig előfordul. Európában a középső és a déli területeken terjedt el, hiányzik az Ibériai-félszigetről, Dél-Franciaországból, a mediterrán szigetvilágból, a Brit szigetekről. Északon Hollandia és Németország, valamint Lengyelország területének jelentős részén nem fordul elő (MiTCHELL-JONES et al., 1999).

Földrajzi változatosság tekintetében két alfaja ismert: a Crocidura leucodon leucodon (HERMANN, 1780) és a Crocidura leucodon narentae BolKAY, 1925, melyeket az Alpokon, Nyugat-Ausztrián, Csehországon és Nyugat-Lengyelországon át húzódó izolációs sáv választ el egymástól (MiTCHELL-JONES et al., 1999). A mezei cickány biometriai jellemzőinek elemzésétől az alacsony fogásszám miatt eltekintettem. A mezei cickány a vizsgált 24 erdősávból 4-ben (17\%) fordult elő (10. térkép). A faj egyedei az összes csapdázott kisemlős $(\mathrm{n}=1645)$ 0,5\%-át tették ki. A fogott 9 példányból 8-nak (89\%) sikerült meghatározni az ivarát, közülük 6 pd nősténynek (75\%), 2 hímnek (25\%) bizonyult.

\subsubsection{Közönséges erdeiegér - Apodemus sylvaticus (LinNAEUS, 1758)}

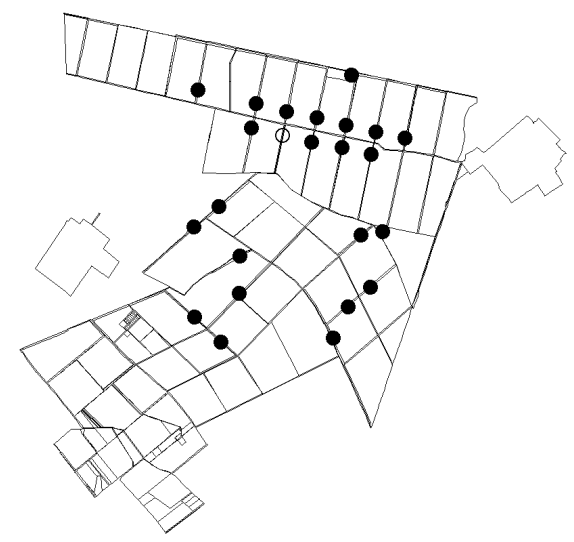

10. térkép: A közönséges erdeiegér előfordulása a LAJTA Projectben

Map 11: Locations of the Wood Mouse in the LAJTA Project 
Elterjedési területe Európára, Kis-Ázsiára és Észak-Afrikára korlátozódik. Európában általánosan elterjedt (MITCHELL-JONES et al., 1999). Földrajzi változatossága, mely elsősorban a földközi-tengeri szigeteken jellemző, főként testméretben és színezetben nyilvánul meg (MitchELL-JONES et al., 1999). A közönséges erdeiegér a vizsgált 24 erdősávból 22-ben (92\%) fordult elő (11. térkép).

\section{4. táblázat: A közönséges erdeiegér biometriai jellemzői}

Table 4: Biometric features of the Wood Mouse

\begin{tabular}{|l|c|c|c|c|c|c|}
\hline \multicolumn{1}{|c|}{$\begin{array}{c}\text { Testméretek } \\
\text { Measurements } \\
\mathrm{n}=82\end{array}$} & $\begin{array}{c}\text { Átlag } \\
\text { Mean }\end{array}$ & Min. & Max. & $\begin{array}{c}\text { CORBET \& } \\
\text { OvENDEN, 1982 }\end{array}$ & $\begin{array}{c}\text { Kzórás } \\
\text { Variance }\end{array}$ & $\begin{array}{c}\text { Konfidencia } \\
\text { intervallum } \\
\text { Confidence interval } \\
(\alpha=0,05)\end{array}$ \\
\hline $\begin{array}{l}\text { Testtömeg (g) } \\
\text { Weight }\end{array}$ & 17,7 & 5,0 & 39,0 & $20-30$ & 6,71 & $17,7 \pm 1,50$ \\
\hline $\begin{array}{l}\text { Testhossz (mm) } \\
\text { Body length }\end{array}$ & 90,3 & 59,0 & 121,0 & $80-105$ & 11,29 & $90,3 \pm 2,54$ \\
\hline $\begin{array}{l}\text { Farokhossz (mm) } \\
\text { Tail length }\end{array}$ & 76,2 & 41,0 & 103,0 & $70-115$ & 10,81 & $76,2 \pm 2,43$ \\
\hline $\begin{array}{l}\text { Hátsó talp hossza }(\mathrm{mm}) \\
\text { Hind foot length }\end{array}$ & 20,3 & 15,0 & 24,0 & $20-24$ & 1,76 & $20,3 \pm 0,39$ \\
\hline $\begin{array}{l}\text { Fülhossz }(\mathrm{mm}) \\
\text { Ear length }\end{array}$ & 15,4 & 10,0 & 22,0 & $15-18,5$ & 2,25 & $15,4 \pm 0,53$ \\
\hline
\end{tabular}

Az 1999-ben végzett mikrohabitat vizsgálat alapján a faj a vizsgált 23 mikrohabitat mindegyikében előfordult (10. ábra). A mikrohabitat preferenciára irányuló tapasztalati és elméleti gyakoriság illesztés $\chi^{2}$ próbával elvégzett illeszkedésvizsgálata alapján $\left(\chi^{2}=78,39\right.$, $\mathrm{p}<0,01, \mathrm{df}=22)$ a populáció egyedeinek mikrohabitatok közti eloszlása eltér az egyenletestől. A fogott egyedek 12\%-a a 4A erdősáv IV. növényzeti egységéböl, a takarmánylucerna, angolperje és betyárkóró borította területen került elö, ez a faj által legkedveltebb mikrohabitat. További, gyakran használt növényzeti egységek még a 4A-II. (réti perje és közönséges tarackbúza), 4C-IV. (fedél rozsnok és közönséges tarackbúza), 4C-III. (angolperje, közönséges tarackbúza, közönséges aszat, betyárkóró), 4A-III. (angolperje, közönséges tarackbúza, közönséges aszat, réti perje), 4C-V. (fedél rozsnok), 4C-VI. (kukorica, közönséges tarackbúza, közönséges aszat).

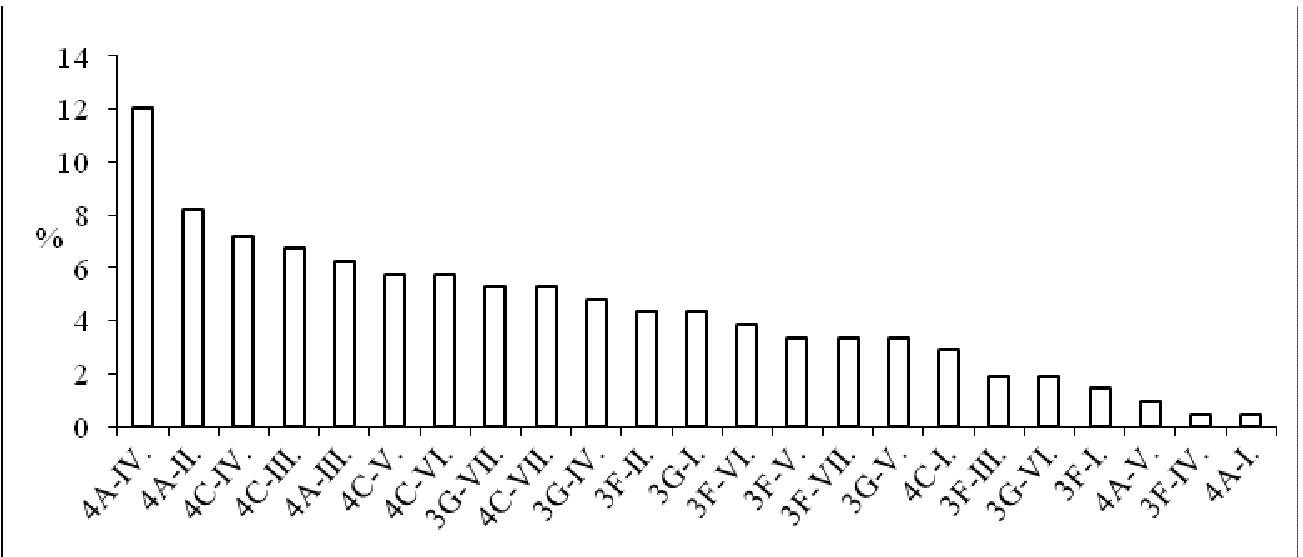

5. ábra: A közönséges erdeiegér mikrohabitat használata $(\mathbf{n = 2 3 5 )}$

Figure 10: Microhabitat use of the Wood Mouse $(n=235)$ 
A 4A kvadrátból származik a legkevésbé használt mikrohabitat is, a 4A-I. (réti és angolperje, közönséges tarackbúza). A mezőgazdasági kultúrákban vizsgált mikrohabitatok közül a kukoricatáblát használta leginkább (4C-VII.), legkevésbé pedig a lucernást (4A-V.).

A faj egyedei az összes csapdázott kisemlös (n=1645) 36,7\%-át tették ki. A fogott 604 példányból 571-nek (95\%) sikerült meghatározni az ivarát, közülük 32\% nősténynek (185 pd), 68\% hímnek (386 pd) bizonyult.

A 3F kvadrátban mindhárom hónapban hím többséget regisztráltam, mely a nőstények számához képest augusztusban volt a legkisebb arányú. A 4A kvadrátban a nőstények aránya folyamatosan nőtt, szeptemberre létszámuk meghaladta a hímekét. A 3G és 4C kvadrátokban a három hónapban sohasem volt hím többség, a nőstények száma augusztusban haladta meg leginkább a hímekét (11. ábra).

Az egyes kvadrátokban tapasztalt ivararány változások közti korrelációs vizsgálat három esetben adott 1 -hez közeli értéket. Ezeket t-teszttel megvizsgálva két esetben szignifikáns összefüggést kaptam (3F-4A: t=3,21, p<0,05), (3F-4C: t=3,08, p<0,05), míg a $3 \mathrm{G}$ és a $4 \mathrm{C}$ kvadrátok ivararány trendje közti korrelációs együttható nem bizonyult szignifikánsnak (3G-4C: $\mathrm{t}=2,33$, NS). Fenti vizsgálat megerősítette, hogy a 3F kvadrátban -a zárt akácosban- tapasztalt trendhez leginkább 4 A és a 4C kvadrátokban tapasztalt ivararány változás iránya tekinthető hasonlónak (5. táblázat).

\section{5. táblázat: Az egyes kvadrátokban tapasztalt ivararány változások közti korrelációs egyuitthatók értékei a közönséges erdeiegér esetében}

Table 5: Correlation coefficients of sex ratio in the examined quadrats for the Wood Mouse

\begin{tabular}{|l|l|l|l|}
\hline & $4 \mathrm{C}$ & $3 \mathrm{~F}$ & $3 \mathrm{G}$ \\
\hline $4 \mathrm{~A}$ & 0,42533 & 0,848973 & $-0,26496$ \\
\hline $4 \mathrm{C}$ & - & 0,839349 & 0,759994 \\
\hline $3 \mathrm{~F}$ & - & - & 0,284603 \\
\hline
\end{tabular}

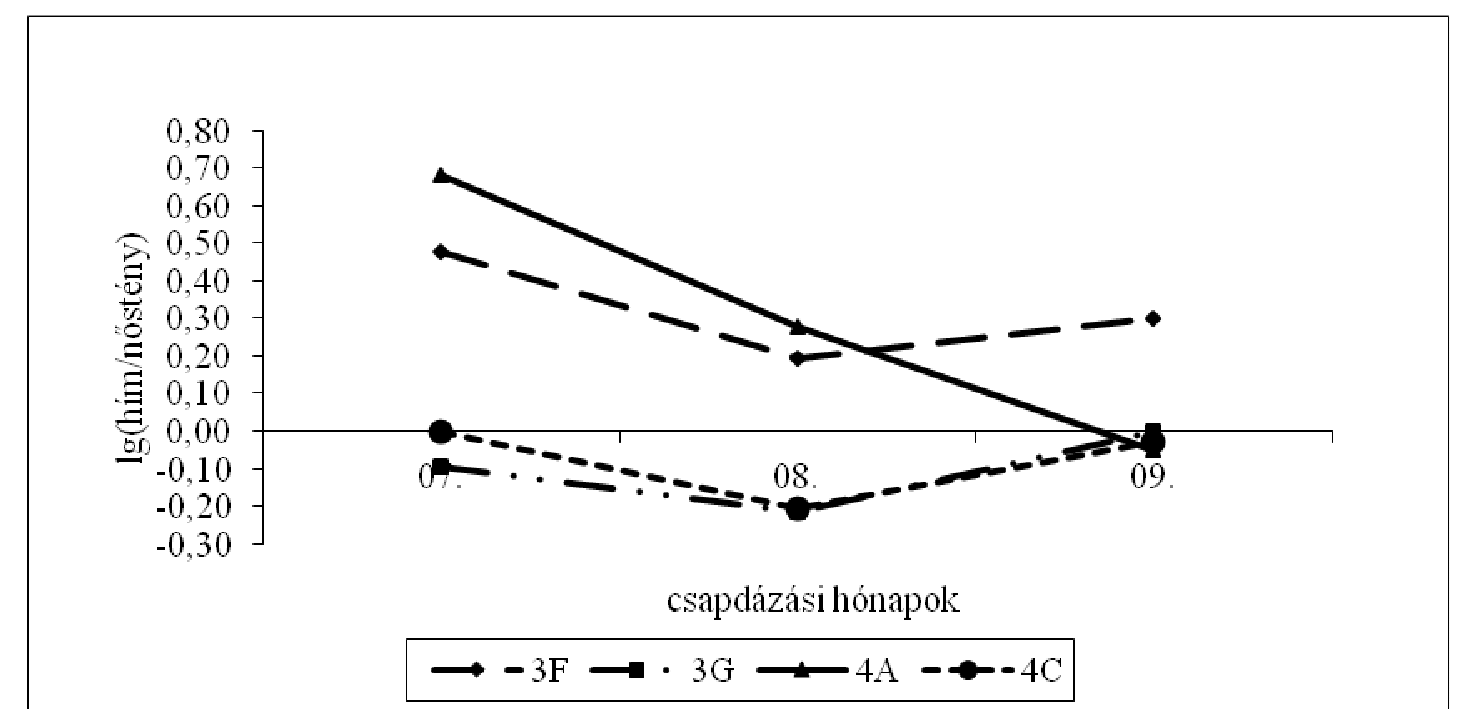

6. ábra: A közönséges erdeiegér ivararányának alakulása (n=216)

Figure 11: Sex ratio of the Wood Mouse $(n=216)$ 
Az egy vegetációs perióduson belüli dinamikát vizsgálva (12. ábra) megállapítható, hogy 1999-ben a négy kvadrátból háromban augusztusi egyben pedig szeptemberi maximum jelentkezett.

A négy habitatban tapasztalt, egy csapdára jutó átlagos fogásszámok közül, varianciaanalízis alapján a 3G-ben és a 4A-ban nem volt eltérés az egyes hónapok között. A $3 \mathrm{~F}$ (one-way ANOVA, $\mathrm{F}_{3,144}=12,28, \mathrm{p}<0,05$ ) és a $4 \mathrm{C}$ (one-way ANOVA, $\mathrm{F}_{3,144}=6,30$, p $<0,05)$ kvadrátok esetében a varianciaanalízis különbséget jelzett. Ezt ellenőrizve TUKEY HSD teszttel, a 3F kvadrát esetében a júliusi és augusztusi, valamint az augusztusi és szeptemberi, a 4C kvadrátban pedig a júliusi és szeptemberi fogásszámok különböztek szignifikánsan (6.-7. táblázat). A tesztek alapján tehát a közönséges erdeiegér augusztusi maximumát sikerült kimutatni a $3 \mathrm{~F}$ jelü akácosban, ill. a júliusban észlelt mennyiségét meghaladó denzitását szeptemberben, a 4C kvadrát területén.

6. táblázat: A TUKEY HSD teszt eredményei a közönséges erdeiegér havi egyedszám változásának összehasonlításában, a 3F kvadrátban. A kiemelt értékek p<0,05 szinten szignifikáns különbséget jeleznek.

Table 6: Results of the TUKEY HSD test for monthly number changes of the Wood Mouse in the 3F quadrat. The key values of $\mathrm{p}<0,05$ indicates significant difference.

\begin{tabular}{|l|c|c|c|}
\hline \multicolumn{1}{|c|}{$\begin{array}{c}\text { Időszak } \\
\text { Period }\end{array}$} & $\begin{array}{c}\text { Július } \\
\text { July }\end{array}$ & $\begin{array}{c}\text { Augusztus } \\
\text { August }\end{array}$ & $\begin{array}{c}\text { Szeptember } \\
\text { September }\end{array}$ \\
\hline $\begin{array}{l}\text { Átlag \& Konfidencia } \\
\text { intervallum } \\
\text { Mean \& Confidence interval }\end{array}$ & $0,20 \pm 0,45$ & $0,51 \pm 0,71$ & $0,02 \pm 0,14$ \\
\hline $\mathbf{n}$ & 49 & 49 & 49 \\
\hline $\begin{array}{l}\text { Július } \\
\text { July }\end{array}$ & - & 0,01 & 0,15 \\
\hline $\begin{array}{l}\text { Augusztus } \\
\text { August }\end{array}$ & - & - & 0,00 \\
\hline
\end{tabular}

7. táblázat: A TUKEY HSD teszt eredményei a közönséges erdeiegér havi egyedszám változásának összehasonlításában, a 4C kvadrátban. A kiemelt értékek p $<0,05$ szinten szignifikáns különbséget jeleznek.

Table 7: Results of the TUKEY HSD test for monthly number changes of the Wood Mouse in the 4C quadrat. The key values of $\mathrm{p}<0,05$ indicates significant difference.

\begin{tabular}{|l|c|c|c|}
\hline \multicolumn{1}{|c|}{$\begin{array}{c}\text { Idöszak } \\
\text { Period }\end{array}$} & $\begin{array}{c}\text { Július } \\
\text { July }\end{array}$ & $\begin{array}{c}\text { Augusztus } \\
\text { August }\end{array}$ & $\begin{array}{c}\text { Szeptember } \\
\text { September }\end{array}$ \\
\hline $\begin{array}{l}\text { Átlag \& Konfidencia } \\
\text { intervallum } \\
\text { Mean \& Confidence interval }\end{array}$ & $0,16 \pm 0,51$ & $0,41 \pm 0,70$ & $0,73 \pm 1,07$ \\
\hline $\mathbf{n}$ & 49 & 49 & 49 \\
\hline $\begin{array}{l}\text { Július } \\
\text { July }\end{array}$ & - & 0,28 & 0,00 \\
\hline $\begin{array}{l}\text { Augusztus } \\
\text { August }\end{array}$ & - & - & 0,11 \\
\hline
\end{tabular}


Egy hónapon belül összehasonlítva az egyes kvadrátokban tapasztalt denzitás értékeket a varianciaanalízis csak szeptemberben jelzett különbséget (one-way ANOVA, $\mathrm{F}_{4,192}=9,43$ $\mathrm{p}<0,05)$. A TUKEY HSD teszt alapján a $4 \mathrm{C}$ kvadrátban, szeptember hónapban mind a három másik habitathoz képest több közönséges erdeiegér fordult elő (8. táblázat).

8. táblázat: A TuKEY HSD teszt eredményei a közönséges erdeiegér, négy különböző kvadrátban kimutatott denzitás értékeinek összehasonlításában, szeptember hónapban. A kiemelt értékek $p<0,05$ szinten szignifikáns különbséget jeleznek.

Table 8: Results of the TUKEY HSD test for density of the Wood Mouse in comparison of four different quadrats in september. The key values of $\mathrm{p}<0,05$ indicates significant difference.

\begin{tabular}{|l|l|l|l|l|}
\hline \multicolumn{1}{|c|}{$\begin{array}{c}\text { Kvadrát } \\
\text { Quadrat }\end{array}$} & \multicolumn{1}{|c|}{$\mathbf{3 F}$} & \multicolumn{1}{|c|}{$\mathbf{3 G}$} & \multicolumn{1}{|c|}{$\mathbf{4 C}$} \\
\hline $\begin{array}{l}\text { Átlag \& Konfidencia } \\
\text { intervallum } \\
\text { Mean \& Confidence interval }\end{array}$ & $0,0 \pm 0,14$ & $0,22 \pm 0,51$ & $0,37 \pm 0,67$ & $0,73 \pm 1,08$ \\
\hline $\mathbf{n}$ & 49 & & & \\
\hline $\mathbf{3 F}$ & - & 49 & 49 & 49 \\
\hline $\mathbf{3 G}$ & - & 0,45 & 0,06 & 0,00 \\
\hline $\mathbf{4 A}$ & - & - & 0,73 & 0,00 \\
\hline
\end{tabular}

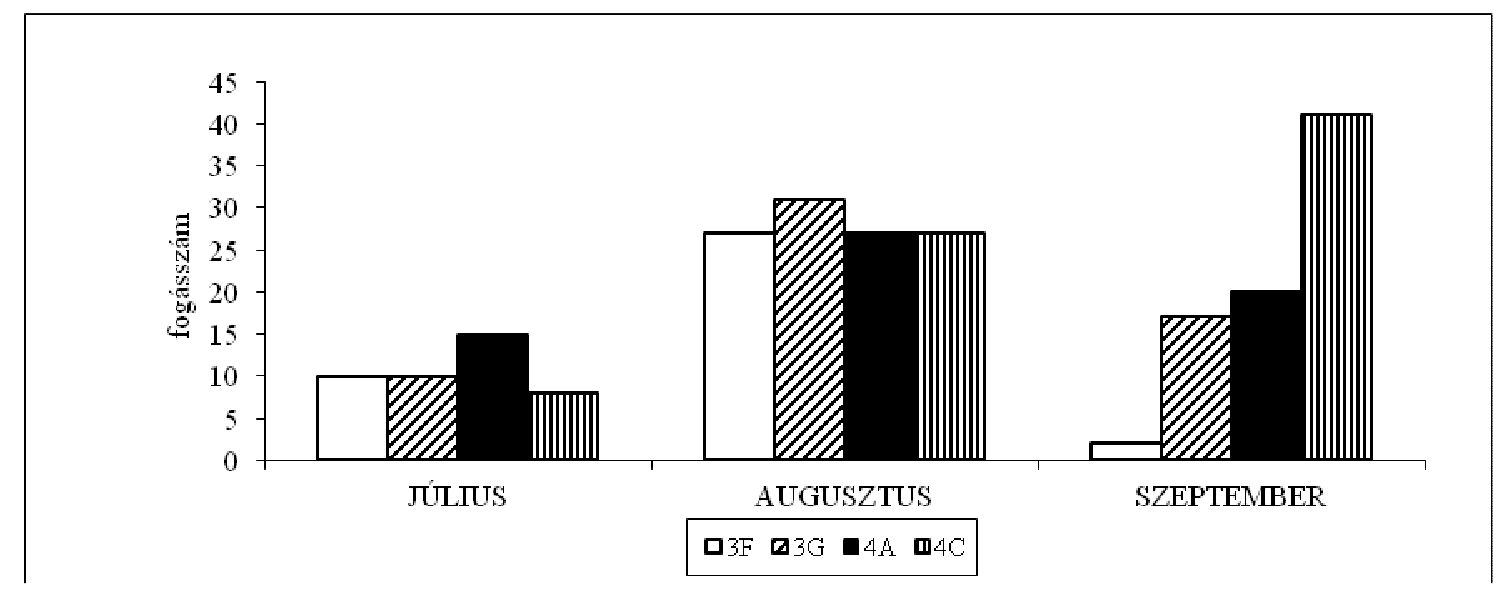

7. ábra: A közönséges erdeiegér egyedszám változása 1999-ben (n=235)

Figure 12: Number changes of the Wood Mouse in $1999(n=235)$

A visszafogási ráta értékei a 3G kvadrát esetében szeptemberi, a többi habitatnál pedig augusztusi maximumot mutattak (13. ábra). 


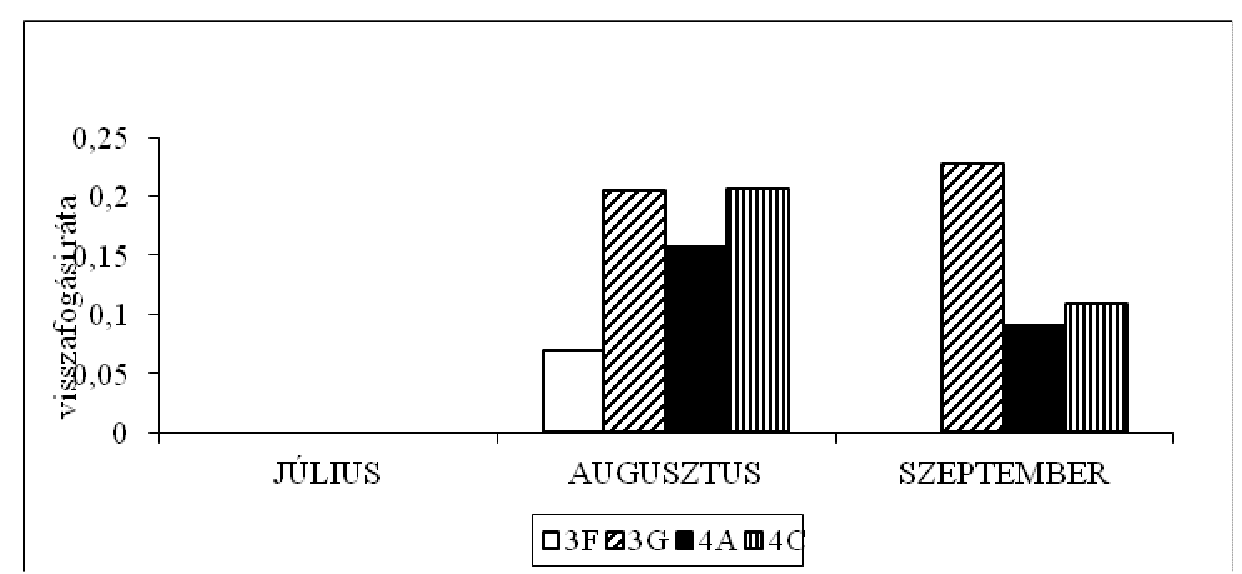

8. ábra: A közönséges erdeiegér visszafogási rátájának alakulása 1999-ben (n=235)

Figure 13: Recapturing rate of the Wood Mouse in $1999(n=235)$

Elemezve a közönséges erdeiegér fogás- visszafogás pozícióinak viszonyát, kiszámoltam kvadrátonként az egy fogás-visszafogás eseményhez tartozó átlagos elmozdulás távolságát. Az X értékek egy átlagos elmozdulás erdősávra merőleges, az Y értékek pedig az erdősávval párhuzamos komponensét mutatják (9. táblázat). Látható, hogy a 3G kvadrátban az X és Y értékek közt nincs jelentős különbség, ellenben a másik két kvadrátban mintegy négyszer nagyobb az X értéke Y-nál. Az arány arra utal, hogy amíg a 3G területen a közönséges erdeiegér mozgása nem mutat határozott irányfüggést, addig a másik két kvadrátban az erdősávhoz képest keresztirányban nagyobb távolságot tesznek meg az állatok, mint az erdősáv mentén.

\section{9. táblázat: A közönséges erdeiegér kvadrátonkénti átlagos elmozdulásának összetevői}

Table 9: Average moving by quadrats of the wood mouse

\begin{tabular}{|l|c|c|}
\hline & $\mathbf{X}$ & $\mathbf{Y}$ \\
\hline 3G & 9,23 & 10,00 \\
\hline $\mathbf{4 A}$ & 15,00 & 3,75 \\
\hline $\mathbf{4 C}$ & 9,17 & 2,50 \\
\hline
\end{tabular}

Az évek közötti dinamika tekintetében (14. ábra), négy erdősáv közül, melyeket négy, ill. öt éven keresztül vizsgáltam, a 4C-ben és a 3F jelü akácosban 1997-ben tapasztaltam denzitás maximumát $\left(r^{2}=0,747\right)$, míg a másik két kvadrátban 1999-ben $\quad\left(r^{2}=0,9919\right.$; $\left.\mathrm{r}^{2}=0,7834\right)$. A 100 csapdaéjszakára jutó legkisebb fogási értékeket három erdősávban 1992ben, egyben pedig 1996-ban mutatta a közönséges erdeiegér populáció. Az egyedszám változások trendje az akácosban másodfokú görbével, a $3 \mathrm{G}$ és $4 \mathrm{~A}$ sávokban lineáris regresszióval volt közelíthető, a 4C-ben pedig nem lehetett rá trendvonalat illeszteni.

A Lloyd-féle „foltosság” (patchiness) értékei alapján (10. táblázat) kitünik, hogy a 10 egyednél nagyobb példányszámban csapdázott habitatokban 17 esetben aggregáltságot, 8 esetben pedig szegregáltságot mutattak a közönséges erdeiegér állományok. A foltosság értékek és a denzitás között nem tapasztaltam kimutatható összefüggést. 
10. táblázat: A közönséges erdeiegér populációk Lloyd-féle foltosság értékei

Table 10: Lloyd's patchiness values of the Wood Mouse's populations

\begin{tabular}{|l|c|c|c|c|c|c|}
\hline $\begin{array}{l}\text { Erdősáv } \\
\text { Forest belt }\end{array}$ & $\begin{array}{c}\mathbf{1 9 9 2 .} \\
\text { július }\end{array}$ & $\begin{array}{c}\mathbf{1 9 9 4 .} \\
\text { július }\end{array}$ & $\begin{array}{c}\mathbf{1 9 9 7 .} \\
\text { július }\end{array}$ & $\begin{array}{c}\mathbf{1 9 9 9 .} \\
\text { július }\end{array}$ & $\begin{array}{c}\mathbf{1 9 9 9 .} \\
\text { augusztus }\end{array}$ & $\begin{array}{c}1999 . \\
\text { szeptember }\end{array}$ \\
\hline $\mathbf{3 F}$ & - & 0,00 & 0,88 & 0,98 & 0,94 & - \\
\hline $\mathbf{3 G}$ & - & - & - & - & 1,48 & 1,62 \\
\hline 3H & 0,68 & - & 2,03 & - & - & - \\
\hline 3I & 1,09 & - & 1,47 & - & - & - \\
\hline 4A & - & - & 1,36 & 4,05 & 1,42 & 1,51 \\
\hline 4C & - & 2,72 & - & - & 1,47 & 1,74 \\
\hline 68C & - & - & 1,11 & - & - & - \\
\hline 70B & - & - & 1,74 & - & - & - \\
\hline 70D & - & - & 1,50 & - & - & - \\
\hline 69F & - & 0,81 & 1,21 & - & - & - \\
\hline 69B & - & - & 1,91 & - & - & - \\
\hline 69E & - & - & 0,98 & - & - & - \\
\hline 70A & - & - & 0,68 & - & - & - \\
\hline
\end{tabular}
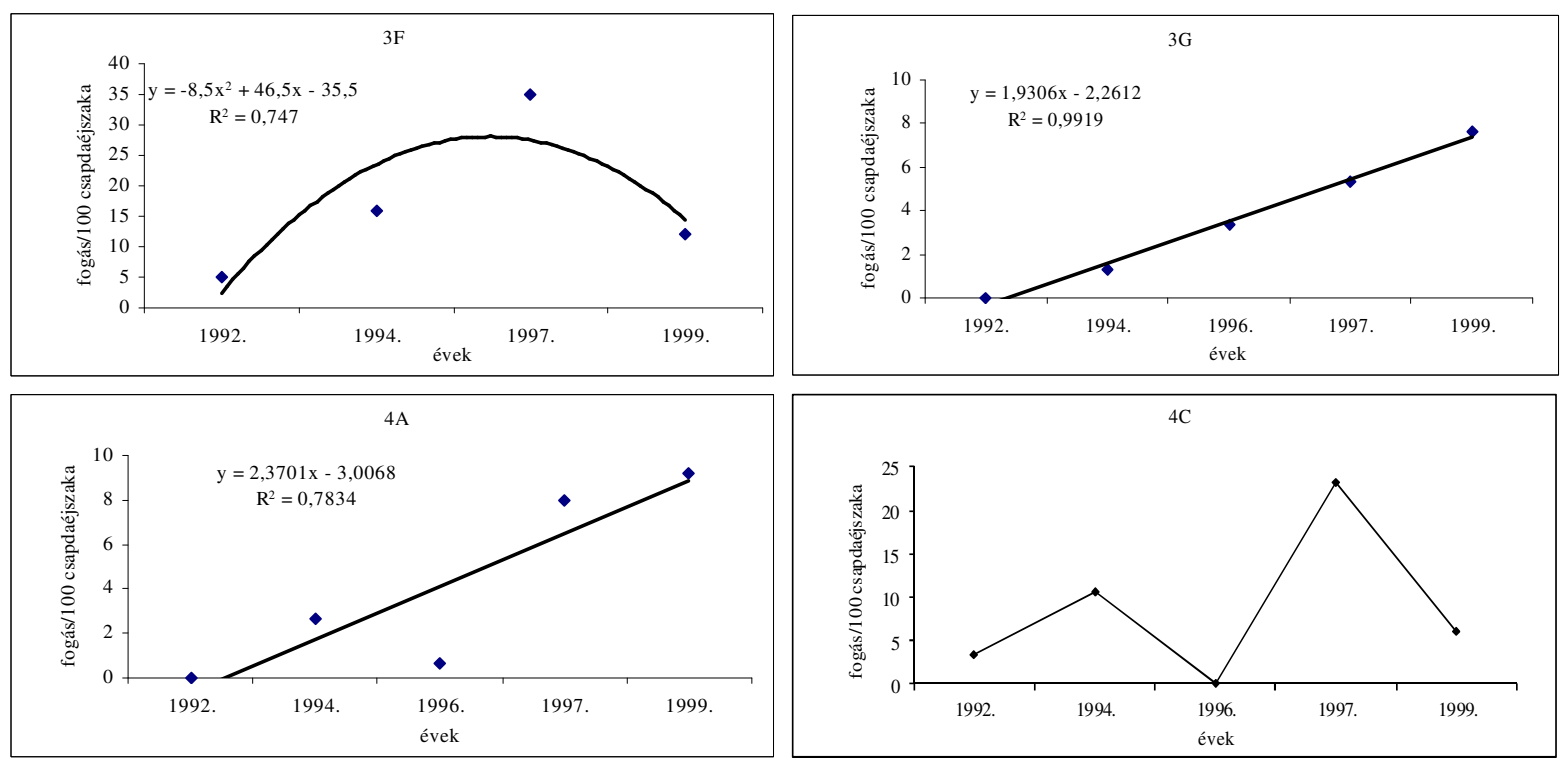

9. ábra: A közönséges erdeiegér egyedszámának változása 1992 és 1999 között

Figure 14: Number changes of the Wood Mouse between 1992-1999

441 megmért állat alapján az átlagos testtömeg évenkénti változását a 15. ábra szemlélteti, melyen feltüntettem az átlag standard hibáját is (SE). A legmagasabb értéket 1997-ben kaptam 24,2 grammal, a legalacsonyabb pedig az 1992. évi testtömeg $(17,7 \mathrm{~g})$.

A három évben tapasztalt átlagos testtömegek varianciaanalízis alapján eltérönek bizonyultak (one-way ANOVA, $\mathrm{F}_{3,144}=12,28$, p<0,05). Ezt ellenörizve TUKEY HSD teszttel, az 1997-ben mért átlagos testtömeg a közönséges erdeiegér esetében szignifikánsan nagyobb volt mind az 1992-ben, mind az 1999-ben tapasztaltnál (7, ill. 5 grammal) (11. táblázat). 
11. táblázat: A TUKEY HSD teszt eredményei a közönséges erdeiegér évenkénti átlagos testtömegének összehasonlításában. A kiemelt értékek $p<0,05$ szinten szignifikáns különbséget jeleznek.

Table 11: Results of the TUKEY HSD test for yearly average weight of the Wood Mouse in the $3 \mathrm{~F}$ quadrat. The key values of $p<0,05$ indicates significant difference.

\begin{tabular}{|l|c|c|c|}
\hline \multicolumn{1}{|c|}{$\begin{array}{c}\text { Év } \\
\text { Year }\end{array}$} & $\mathbf{1 9 9 2}$ & $\mathbf{1 9 9 7}$ & $\mathbf{1 9 9 9}$ \\
\hline $\begin{array}{l}\text { Átlag \& Konfidencia } \\
\text { intervallum } \\
\text { Mean \& Confidence interval }\end{array}$ & $17,71 \pm 6,71$ & $24,18 \pm 8,02$ & $19,19 \pm 6,61$ \\
\hline $\mathbf{n}$ & 77 & 167 & 191 \\
\hline $\mathbf{1 9 9 2}$ & - & 0,00 & 0,28 \\
\hline $\mathbf{1 9 9 7}$ & - & - & 0,00 \\
\hline
\end{tabular}

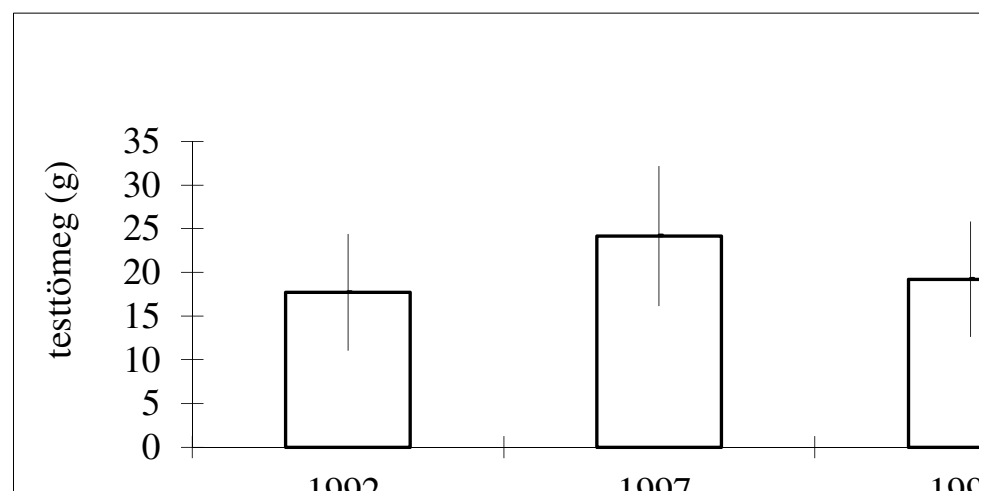

10. ábra: A közönséges erdeiegér átlagos testtömegének változása (n=441)

Figure 15: Changes in average weight of the Wood Mouse $(n=441)$

\subsubsection{Sárganyakú erdeiegér - Apodemus flavicollis (MELCHIOR, 1834)}

A Nyugat-Palearktikumban terjedt el: Európában és a Közel-Keleten. Európai populációi Észak-Spanyolországtól Skandinávia déli területeiig élnek. Hiányzik Nyugat-Európa atlantikus partvidékéről, Írországból, Skóciából és Walesből, továbbá a mediterrán szigetvilágból (MITCHELL-JONES et al., 1999). Földrajzi változatossága elsősorban testméretben és színezetben nyilvánul meg (MiTCHELL-JONES et al., 1999). 


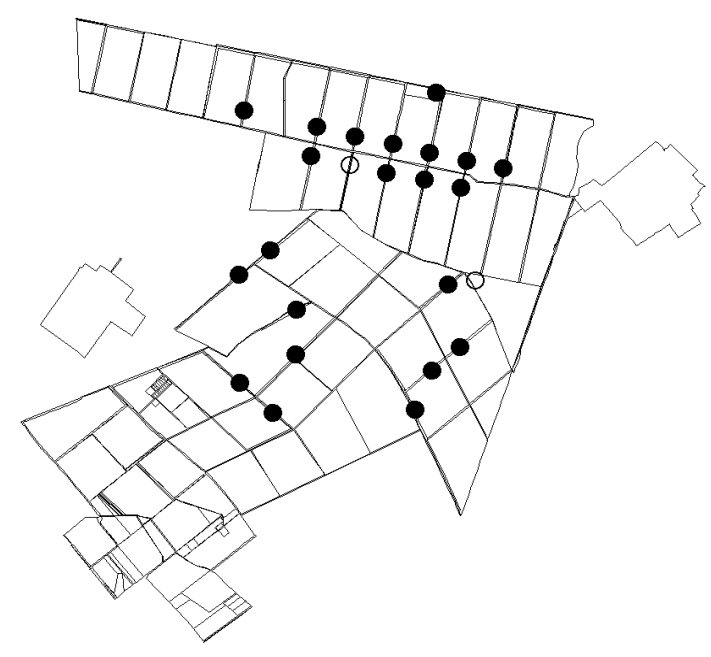

\section{1. térkép: A sárganyakú erdeiegér előfordulása a LAJTA Projectben \\ Map 12: Locations of the Yellow-necked Mouse in the LAJTA Project}

A sárganyakú erdeiegér a vizsgált 24 erdősávból 22-ben (92\%) fordult elő (12. térkép). Biometriai jellemzőit a 12. táblázat tartalmazza.

\section{2. táblázat: A sárganyakú erdeiegér biometriai jellemzői}

Table 12: Biometric features of the Yellow-necked Mouse

\begin{tabular}{|l|c|c|c|c|c|c|}
\hline \multicolumn{1}{|c|}{$\begin{array}{c}\text { Testméretek } \\
\text { Measurements } \\
\mathrm{n}=132\end{array}$} & $\begin{array}{c}\text { Átlag } \\
\text { Mean }\end{array}$ & Min. & Max. & $\begin{array}{c}\text { CORBET \& } \\
\text { OVENDEN, 1982 }\end{array}$ & $\begin{array}{c}\text { Konfidencia } \\
\text { Variance } \\
\text { intervallum } \\
\text { Confidence interval } \\
(\alpha=0,05)\end{array}$ \\
\hline $\begin{array}{l}\text { Testtömeg (g) } \\
\text { Weight }\end{array}$ & 27,0 & 4,0 & 55,0 & $20-50$ & 10,87 & $27,0 \pm 1,85$ \\
\hline $\begin{array}{l}\text { Testhossz (mm) } \\
\text { Body length }\end{array}$ & 102,7 & 65,0 & 125,0 & $90-121$ & 9,46 & $102,7 \pm 1,61$ \\
\hline $\begin{array}{l}\text { Farokhossz (mm) } \\
\text { Tail length }\end{array}$ & 92,9 & 34,0 & 117,0 & $95-135$ & 12,62 & $92,9 \pm 2,15$ \\
\hline $\begin{array}{l}\text { Hátsó talp hossza (mm) } \\
\text { Hind foot length }\end{array}$ & 22,8 & 15,0 & 27,0 & $23,5-26,5$ & 1,71 & $22,8 \pm 1,71$ \\
\hline $\begin{array}{l}\text { Fülhossz (mm) } \\
\text { Ear length }\end{array}$ & 16,9 & 6,0 & 24,0 & $16-20$ & 2,16 & $16,9 \pm 0,39$ \\
\hline
\end{tabular}

Az 1999-ben végzett mikrohabitat elemzés szerint a faj a vizsgált 23 mikrohabitat 74\%-ában -17 mikrohabitatban- fordult elő. A mikrohabitat preferenciára irányuló tapasztalati és elméleti gyakoriság illesztés $\chi^{2}$ próbával elvégzett illeszkedésvizsgálata alapján $\left(\chi^{2}=131,10\right.$ $\mathrm{p}<0,01, \mathrm{df}=22$ ) a populáció egyedeinek mikrohabitatok közti eloszlása markánsan eltér az egyenletestöl. A fogott egyedek 2\%-a a 3F kvadrát III. növényzeti egységéből került elö, amely zárt akácos, kinincs cserjeszinttel, réti perje, fedél rozsnok és piros árvacsalán alkotta gyepszinttel (16. ábra). Ez a faj által legkedveltebb mikrohabitat. Elöfordulása 70\%-ban a 3F kvadrátra -mely zárt, jól struktúrált faállománnyal és cserjeszinttel bíró akácoskoncentrálódott. A preferált mikrohabitatok gyepszintjét a közönséges tarackbúza, a piros árvacsalán, a fedél rozsnok és a csomós ebír alkotja. Egyáltalán nem használta a lucerna (4AV,), a kukorica (4C-VII.) és a tárcsázott borsótarló (4C-I.) mikrohabitatokat. 


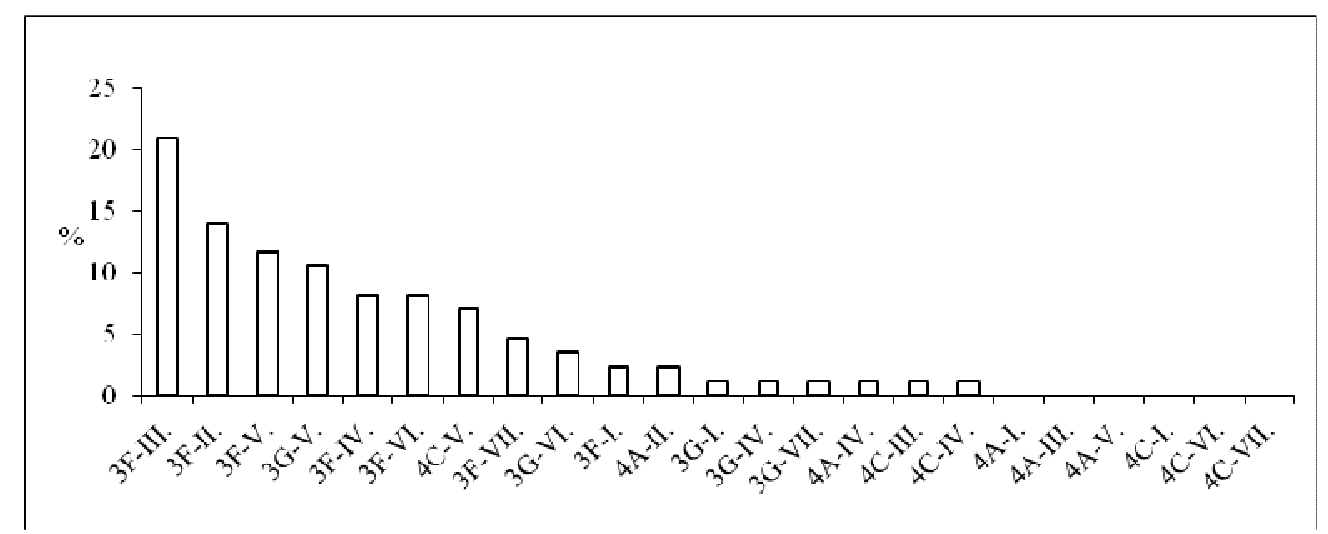

\section{1. ábra: A sárganyakú erdeiegér mikrohabitat használata $(\mathbf{n = 8 7})$}

Figure 16: Microhabitat use of the Yellow-necked Mouse $(n=87)$

A faj egyedei az összes csapdázott kisemlös (n=1645) 20,7\%-át tették ki. A fogott 340 példányból 328-nak (96\%) sikerült meghatározni az ivarát, közülük 39\% nősténynek (128 pd), $61 \%$ hímnek (200 pd) bizonyult.

Az ivararány szezonális vizsgálatára a kis egyedszám miatt csak egy habitatban kerülhetett sor. A júliusban tapasztalt nőstény többséget augusztusra felváltja a hímek túlsúlya, mely szeptemberre némileg csökkenve megmarad (17. ábra).

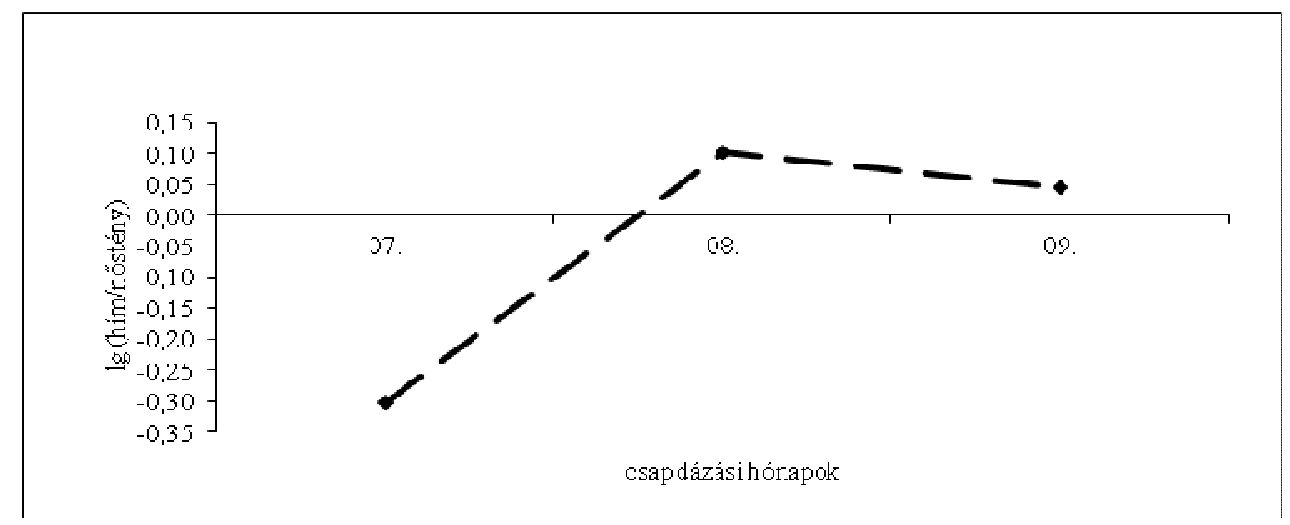

12. ábra: A sárganyakú erdeiegér ivararányának alakulása 1999-ben, a 3F kvadrátban

Figure 17: Sexual structure of the Yellow-necked Mouse in 1999, in the quadrat 3F (n=64)

Az egy vegetációs perióduson belüli dinamikát vizsgálva (18. ábra) megállapítható, hogy 1999-ben a négy kvadrátból kettőben augusztusi (3F és 3G), kettőben pedig szeptemberi (4A és 4C) maximum jelentkezett.

A négy habitatban tapasztalt denzitás változások közül, varianciaanalízis alapján a $4 \mathrm{~A}-$ ban nem volt eltérés az egyes hónapok között. A 3F (one-way ANOVA, $\mathrm{F}_{3,144}=9,18$ $\mathrm{p}<0,05$ ) és a $3 \mathrm{G}$ (one-way ANOVA, $\mathrm{F}_{3,144}=3,59, \mathrm{p}<0,05$ ), valamint a $4 \mathrm{C}$ (one-way ANOVA, $\left.\mathrm{F}_{3,144}=3,25, \quad \mathrm{p}<0,05\right)$ kvadrátok esetében a varianciaanalízis különbséget jelzett. Ezt ellenőrizve TUKEY HSD teszttel, a 3F kvadrát esetében a júliusi és augusztusi, a 3G esetében a júliusi és augusztusi és az augusztusi és szeptemberi, a 4C kvadrátban pedig szintén az augusztusi és szeptemberi denzitások különböztek szignifikánsan (13-15. táblázat). A tesztek alapján tehát augusztusban a sárganyakú erdeiegér nagyobb egyedszámban volt jelen a $3 \mathrm{~F}$ jelü akácosban, mint júliusban. A 3G kvadrátban augusztusi, a 4C-ben pedig szeptemberi maximuma volt szignifikáns. 
13. táblázat: A TUKEY HSD teszt eredményei a sárganyakú erdeiegér havi egyedszám változásának összehasonlításában, a 3F kvadrátban. A kiemelt érték p<0,05 szinten szignifikáns különbséget jelez.

Table 13: Results of the TUKEY HSD test for monthly number changes of the Yellow-necked Mouse in the 3F quadrat. The key values of $\mathrm{p}<0,05$ indicates significant difference.

\begin{tabular}{|l|c|c|c|}
\hline \multicolumn{1}{|c|}{$\begin{array}{c}\text { Időszak } \\
\text { Period }\end{array}$} & $\begin{array}{c}\text { Július } \\
\text { July }\end{array}$ & $\begin{array}{c}\text { Augusztus } \\
\text { August }\end{array}$ & $\begin{array}{c}\text { Szeptember } \\
\text { September }\end{array}$ \\
\hline $\begin{array}{l}\text { Átlag \& Konfidencia } \\
\text { intervallum } \\
\text { Mean \& Confidence interval }\end{array}$ & $0,06 \pm 0,31$ & $0,65 \pm 0,92$ & $0,37 \pm 0,6$ \\
\hline $\mathbf{n}$ & 49 & 49 & 49 \\
\hline $\begin{array}{l}\text { Július } \\
\text { July }\end{array}$ & - & 0,00 & 0,06 \\
\hline $\begin{array}{l}\text { Augusztus } \\
\text { August }\end{array}$ & - & - & 0,09 \\
\hline
\end{tabular}

14. táblázat: A TuKEY HSD teszt eredményei a sárganyakú erdeiegér havi egyedszám változásának összehasonlításában, a 3G kvadrátban. A kiemelt érték p<0,05 szinten szignifikáns különbséget jelez.

Table 14: Results of the TUKEY HSD test for monthly number changes of the Yellow-necked Mouse in the 3G quadrat. The key values of $\mathrm{p}<0,05$ indicates significant difference.

\begin{tabular}{|l|c|c|c|}
\hline \multicolumn{1}{|c|}{$\begin{array}{c}\text { Időszak } \\
\text { Period }\end{array}$} & $\begin{array}{c}\text { Július } \\
\text { July }\end{array}$ & $\begin{array}{c}\text { Augusztus } \\
\text { August }\end{array}$ & $\begin{array}{c}\text { Szeptember } \\
\text { September }\end{array}$ \\
\hline $\begin{array}{l}\text { Átlag \& Konfidencia } \\
\text { intervallum } \\
\text { Mean \& Confidence interval }\end{array}$ & $0,00 \pm 0,00$ & $0,20 \pm 0,58$ & $0,10 \pm 0,31$ \\
\hline $\mathbf{n}$ & 49 & 49 & 49 \\
\hline $\begin{array}{l}\text { Július } \\
\text { July }\end{array}$ & - & 0,02 & 0,37 \\
\hline $\begin{array}{l}\text { Augusztus } \\
\text { August }\end{array}$ & - & - & 0,37 \\
\hline
\end{tabular}

15. táblázat: A TUKEY HSD teszt eredményei a sárganyakú erdeiegér havi egyedszám változásának összehasonlításában, a 4C kvadrátban. A kiemelt érték p $<0,05$ szinten szignifikáns különbséget jelez.

Table 15: Results of the TUKEY HSD test for monthly number changes of the Yellow-necked Mouse in the 4C quadrat. The key values of $\mathrm{p}<0,05$ indicates significant difference.

\begin{tabular}{|l|c|c|c|}
\hline \multicolumn{1}{|c|}{$\begin{array}{c}\text { Időszak } \\
\text { Period }\end{array}$} & $\begin{array}{c}\text { Július } \\
\text { July }\end{array}$ & $\begin{array}{c}\text { Augusztus } \\
\text { August }\end{array}$ & $\begin{array}{c}\text { Szeptember } \\
\text { September }\end{array}$ \\
\hline $\begin{array}{l}\text { Átlag \& Konfidencia } \\
\text { intervallum } \\
\text { Mean \& Confidence interval }\end{array}$ & $0,02 \pm 0,14$ & $0,00 \pm 0,00$ & $0,14 \pm 0,50$ \\
\hline $\mathbf{n}$ & 49 & 49 & 49 \\
\hline $\begin{array}{l}\text { Július } \\
\text { July }\end{array}$ & - & 0,94 & 0,11 \\
\hline $\begin{array}{l}\text { Augusztus } \\
\text { August }\end{array}$ & - & - & 0,05 \\
\hline
\end{tabular}


16. táblázat: A TUKEY HSD teszt eredményei a sárganyakú erdeiegér, négy különböző kvadrátban kimutatott denzitás értékeinek összehasonlításában, augusztus hónapban. A kiemelt értékek p<0,05 szinten szignifikáns különbséget jeleznek.

Table 16: Results of the TUKEY HSD test for density of Yellow-necked Mouse in comparison of four different quadrats in august. The key values of $p<0,05$ indicates significant difference.

\begin{tabular}{|l|c|c|c|c|}
\hline \multicolumn{1}{|c|}{$\begin{array}{c}\text { Kvadrát } \\
\text { Quadrat }\end{array}$} & $\mathbf{3 F}$ & $\mathbf{3 G}$ & $\mathbf{4 A}$ & $\mathbf{4 C}$ \\
\hline $\begin{array}{l}\text { Átlag \& Konfidencia } \\
\text { intervallum } \\
\text { Mean \& Confidence interval }\end{array}$ & $0,65, \pm 0,92$ & $0,20 \pm 0,58$ & $0,02 \pm 0,14$ & $0,00 \pm 0,00$ \\
\hline $\mathbf{n}$ & 49 & 49 & 49 & 49 \\
\hline $\mathbf{3 F}$ & - & 0,00 & 0,00 & 0,00 \\
\hline $\mathbf{3 G}$ & - & - & 0,35 & 0,25 \\
\hline $\mathbf{4 A}$ & - & - & - & 0,99 \\
\hline
\end{tabular}

Egy hónapon belül összehasonlítva az egyes kvadrátokban tapasztalt denzitás értékeket a varianciaanalízis augusztusban és szeptemberben jelzett különbséget (one-way ANOVA, $\mathrm{F}_{4,192}=14,91 \mathrm{p}<0,05$ ) és (one-way ANOVA, $\mathrm{F}_{4,192}=4,79 \mathrm{p}<0,05$ ), a kvadrátok között. A TUKEY HSD teszt alapján a 3F kvadrátban, augusztusban szignifikánsan több egyed fordult elő, mint a másik háromban, szeptemberben pedig a 3G és a 4A kvadrátok denzitását haladta meg a 3F kvadrát populációja. (16-17. táblázat).

17. táblázat: A TUKEY HSD teszt eredményei a sárganyakú erdeiegér, négy különböző kvadrátban kimutatott denzitás értékeinek összehasonlításában, szeptember hónapban. A kiemelt értékek $\mathbf{p}<0,05$ szinten szignifikáns különbséget jeleznek.

Table 17: Results of the TUKEY HSD test for density of Yellow-necked Mouse in comparison of four different quadrats in august. The key values of $\mathrm{p}<0,05$ indicates significant difference.

\begin{tabular}{|l|c|c|c|c|}
\hline \multicolumn{1}{|c|}{$\begin{array}{c}\text { Kvadrát } \\
\text { Quadrat }\end{array}$} & $\mathbf{3 F}$ & $\mathbf{3 G}$ & $\mathbf{4 A}$ & $\mathbf{4 C}$ \\
\hline $\begin{array}{l}\text { Átlag \& Konfidencia } \\
\text { intervallum } \\
\text { Mean \& Confidence interval }\end{array}$ & $0,37 \pm 0,67$ & $0,10 \pm 0,31$ & $0,04 \pm 0,19$ & $0,14 \pm 0,50$ \\
\hline $\mathbf{n}$ & 49 & 49 & 49 & 49 \\
\hline $\mathbf{3 F}$ & - & 0,02 & 0,00 & 0,07 \\
\hline $\mathbf{3 G}$ & - & - & 0,91 & 0,97 \\
\hline $\mathbf{4 A}$ & - & - & - & 0,68 \\
\hline
\end{tabular}




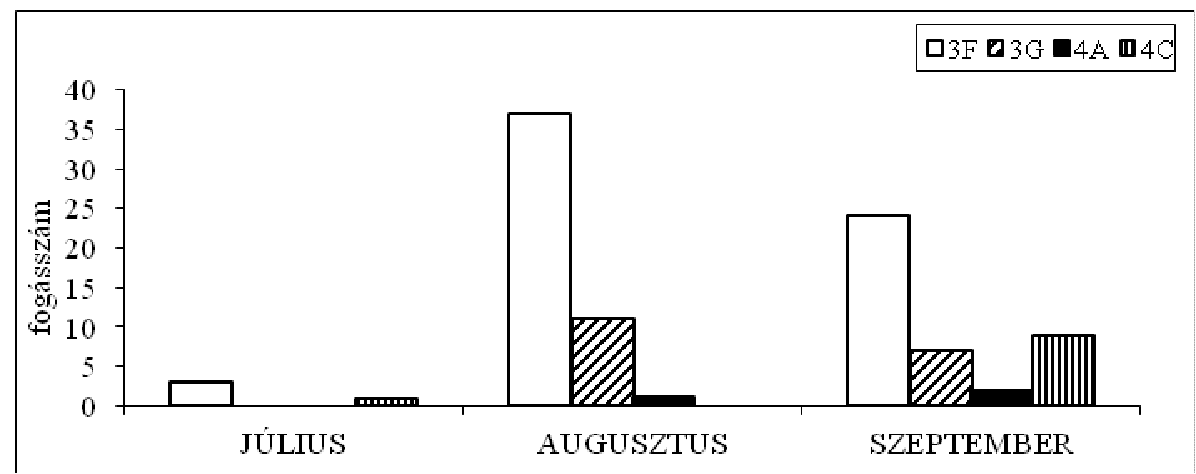

13. ábra: A sárganyakú erdeiegér dinamikája 1999-ben $(\mathbf{n = 8 7})$

Figure 18: Dynamics of the Yellow-necked Mouse in $1999(n=87)$

Az évek közötti dinamika tekintetében a közönséges erdeiegérétől eltérő trendet mutattam ki (19. ábra). Előbbi fajnál a denzitás 1992-től kezdett emelkedni, a sárganyakú erdeiegérnél azonban két esetben ekkor maximális (4A és 4C erdősávok), minimumát pedig három erdősávban (3G, 4A, 4C) 1996-ban és 1997-ben éri el. A trend csak egy esetben volt regressziós görbével leírható $\left(\mathrm{r}^{2}=0,7063\right)$. Feltünő, hogy a $3 \mathrm{~F}$ jelü zárt akácosban tapasztaltam a négy élőhely minimumai közt a legnagyobb értéket.
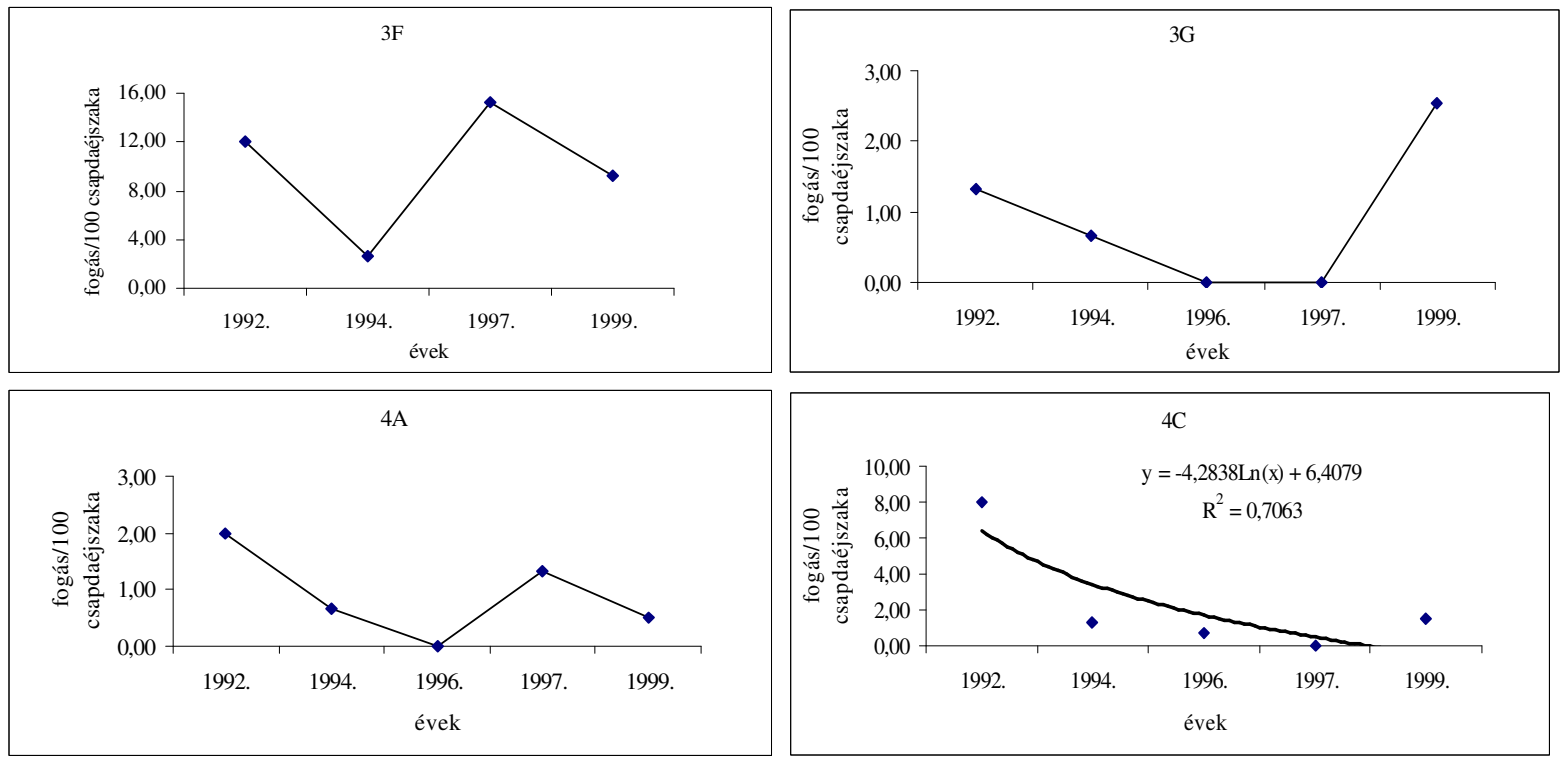

14. ábra: A sárganyakú erdeiegér egyedszámának változása 1992. és 1999. között Figure 19: Number changes of the Yellow-necked Mouse between 1992-1999

A Lloyd-féle „foltosság” (patchiness) értékeit alapján elmondható, hogy a 10 egyednél nagyobb példányszámban csapdázott habitatokban 8 esetben aggregáltságot, 6 esetben pedig szegregáltságot mutattak a sárganyakú erdeiegér állományok (18. táblázat). 
18. táblázat: A sárganyakú erdeiegér populációk Lloyd-féle foltosság értékei

Table 18: Lloyd's patchiness values of the yellow-necked mouse's populations

\begin{tabular}{|l|c|c|c|c|c|}
\hline $\begin{array}{l}\text { Erdősáv } \\
\text { Forest belt }\end{array}$ & $\begin{array}{c}\mathbf{1 9 9 2} \\
\text { július }\end{array}$ & $\begin{array}{c}\mathbf{1 9 9 7} \\
\text { július }\end{array}$ & $\begin{array}{c}\mathbf{1 9 9 9} \\
\text { július }\end{array}$ & $\begin{array}{c}\mathbf{1 9 9 9} \\
\text { augusztus }\end{array}$ & $\begin{array}{c}\mathbf{1 9 9 9} \\
\text { szeptember }\end{array}$ \\
\hline 3F & 0,60 & 0,37 & - & 1,44 & 1,51 \\
\hline $\mathbf{3 G}$ & - & - & - & 3,92 & - \\
\hline 3H & 0,81 & - & - & - & - \\
\hline 3I & 0,87 & - & - & - & - \\
\hline 4A & - & - & 4,05 & - & 1,51 \\
\hline 4C & 2,72 & - & - & - & 1,74 \\
\hline 68D & 1,36 & - & - & - & - \\
\hline 70B & 0,44 & - & - & - & - \\
\hline 70D & 0,68 & - & - & - & - \\
\hline
\end{tabular}

266 megmért állat alapján az átlagos testtömeg évenkénti változását a 20. ábra szemlélteti, melyen feltüntettem az átlag standard hibáját is (SE). A legmagasabb értéket 1997-ben kaptam 33,7 grammal, a legalacsonyabb pedig az 1992. évi testtömeg (23,1 g).

A három évben tapasztalt átlagos testtömegek varianciaanalízis alapján eltérőnek bizonyultak (one-way ANOVA, $\mathrm{F}_{3,144}=8,83 \mathrm{p}<0,05$ ). Ezt ellenőrizve TUKEY HSD teszttel, az 1997-ben mért átlagos testtömeg a sárganyakú erdeiegér esetében szignifikánsan nagyobb volt mind az 1992-ben, mind az 1999-ben tapasztaltnál (7, ill. 6 grammal) (19. táblázat).

19. táblázat: A TUKEY HSD teszt eredményei a sárganyakú erdeiegér évenkénti átlagos testtömegének összehasonlításában. A kiemelt értékek $\mathbf{p}<0,05$ szinten szignifikáns különbséget jeleznek.

Table 19: Results of the TUKEY HSD test for yearly average weight of the Yellow-necked Mouse in the $3 \mathrm{~F}$ quadrat. The key values of $\mathrm{p}<0,05$ indicates significant difference.

\begin{tabular}{|l|c|c|c|}
\hline \multicolumn{1}{|c|}{$\begin{array}{c}\text { Év } \\
\text { Year }\end{array}$} & $\mathbf{1 9 9 2}$ & $\mathbf{1 9 9 7}$ & $\mathbf{1 9 9 9}$ \\
\hline $\begin{array}{l}\text { Átlag \& Konfidencia } \\
\text { intervallum } \\
\text { Mean \& Confidence interval }\end{array}$ & $27,01 \pm 9,83$ & $33,68 \pm 6,99$ & $27,92 \pm 7,16$ \\
\hline $\mathbf{n}$ & 132 & 38 & 76 \\
\hline $\mathbf{1 9 9 2}$ & - & 0,00 & 0,74 \\
\hline $\mathbf{1 9 9 7}$ & - & - & 0,00 \\
\hline
\end{tabular}

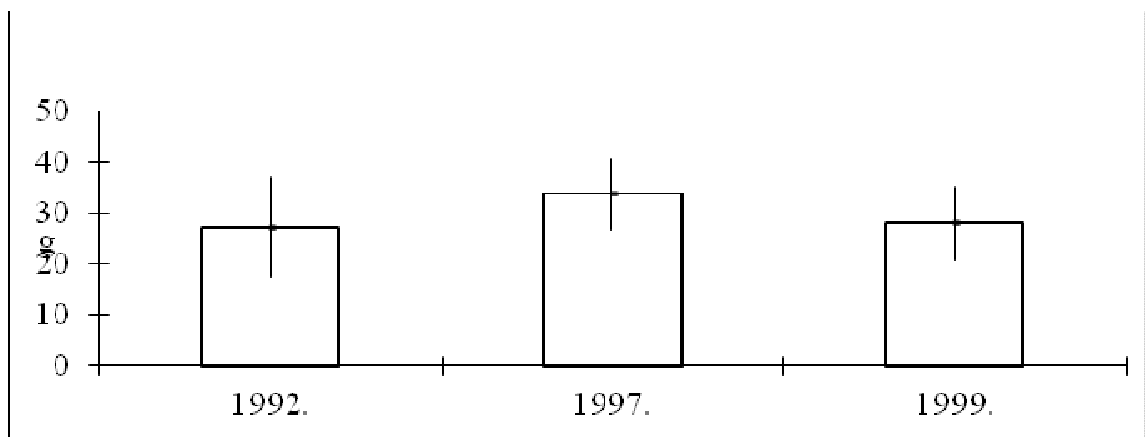

15. ábra: A sárganyakú erdeiegér átlagos testtömeg értékei (n=266)

Figure 20: Average weights of the Yellow-necked Mouse $(n=266)$ 
4.1.6. Törpeegér - Micromys minutus (PALLAS, 1771)

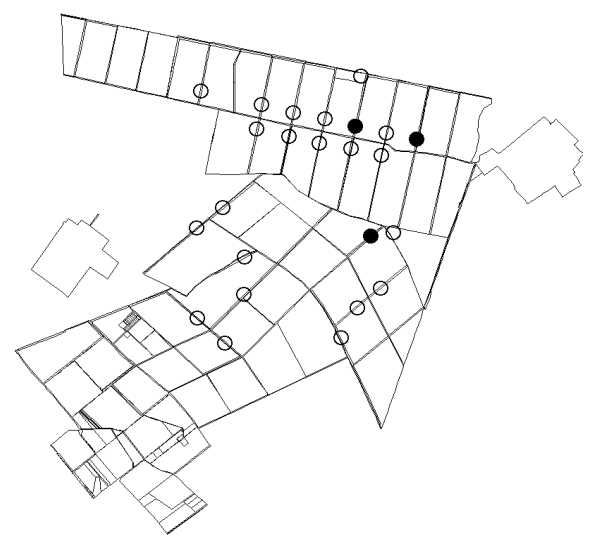

\section{2. térkép: A törpeegér előfordulása a LAJTA Projectben}

Map 13: Locations of the Harvest Mouse in the LAJTA Project

Európai-előázsiai elterjedésű faj, amely Európában Észak-Spanyolországtól DélFinnországig fordul elő (MiTCHELL-JONES et al., 1999). Földrajzi változatosság tekintetében 16 alfaja ismert (MiTCHELL-JONES et al., 1999). A törpeegér a vizsgált 24 erdősávból 3-ban (13\%) fordult elő (13. térkép).

A faj egyedei az összes csapdázott kisemlős (n=1645) 0,4 \%-át tették ki. Az egy vegetációs perióduson belüli és az évek közötti dinamika, valamint a mikrohabitat használat vizsgálatától az alacsony fogásszám miatt eltekintettem.

\subsubsection{Güzüegér - Mus spicilegus PETÉNYI, 1882}

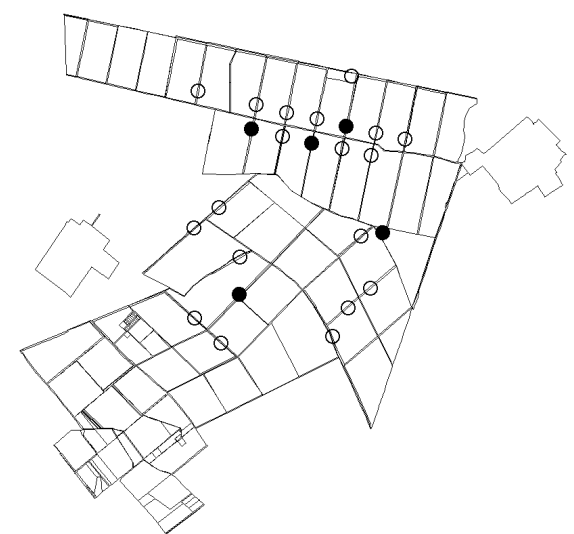

13. térkép: A güzüegér előfordulása a LAJTA Projectben

Map 14: Locations of the Steppe Mouse in the LAJTA Project

Elterjedése Európára korlátozódik, ahol a Fertő-tótól keletre, Magyarországon és DélSzlovákián át Szerbiáig, ill. a Fekete tenger partvidékéig fordul elő. Elszigetelt populációi élnek Montenegróban, Albániában és Görögországban (MITCHELL-JONEs et al., 1999).

Monotipikus faj (MiTCHELL-JONES et al., 1999).

A güzüegér a vizsgált 24 erdősávból 5-ben (21\%) fordult elő (14. térkép). A faj egyedei az összes csapdázott kisemlős (n=1645) 0,4\%-át tették ki. Az egy vegetációs 
perióduson belüli és az évek közötti dinamika, valamint a mikrohabitat használat vizsgálatától az alacsony fogásszám miatt eltekintettem.

4.1.8. Közönséges hörcsög - Cricetus cricetus (LINNEAUS, 1758)

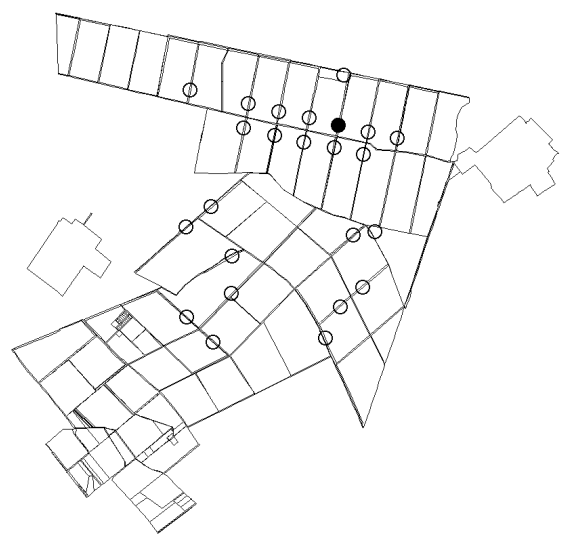

14. térkép: A közönséges hörcsög előfordulása a LAJTA Projectben

Map 15: Locations of the European Hamster in the LAJTA Project

Palearktikus elterjedésű, Nyugat-Európától a Jenyiszejig fordul elő. Európában Hollandia, Belgium, és a francia-német határvidék területétől keletre Fehéroroszországig él. Elterjedésének déli határát Szerbia-Montenegró, valamint Észak-Bulgária képezi (MiTCHELL-JONES et al., 1999).

Két alfaja közül a Cricetus cricetus cricetus keleten, a Cricetus cricetus canescens NEHRING, 1899 nyugaton terjedt el (MITCHELL-JONES et al., 1999). A közönséges hörcsög a vizsgált 24 erdősávból 1-ben (4\%) fordult elö (15. térkép). A faj egyede (1pd) az összes csapdázott kisemlős $(n=1645)$ 0,1\%-át tette ki. Az egy vegetációs perióduson belüli és az évek közötti dinamika, valamint a mikrohabitat használat vizsgálatától az alacsony fogásszám miatt eltekintettem.

4.1.9. Vöröshátú erdeipocok - Clethrionomys glareolus (SCHREBER, 1780)

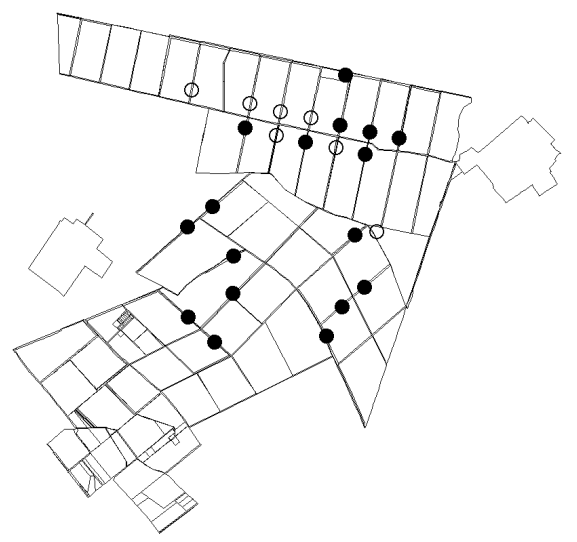

15. térkép: A vöröshátú erdeipocok elöfordulása a LAJTA Projectben

Map 16: Locations of the Bank Vole in the LAJTA Project 
A Nyugat-Palearktisz erdőövében, a Brit szigetektől a Bajkál tóig terjedt el. ÉszakEurópában a sarkkörig, délen Észak-Spanyolországig, az Appenninekig és a Balkánfélszigetig fordul elő (MiTCHELL-JONES et al., 1999). Földrajzi változatosság tekintetében több mint 30 alfaját írták le (MITCHELL-JONES et al., 1999).

A vöröshátú erdeipocok a vizsgált 24 erdősávból 17-ben (71\%) fordult elő (16. térkép). Biometriaia jellemzőit a 20. táblázat tartalmazza.

\section{0. táblázat: A vöröshátú erdeipocok biometriai jellemzői}

Table 20: Biometric features of the Bank Vole

\begin{tabular}{|l|c|c|c|c|c|c|}
\hline \multicolumn{1}{|c|}{$\begin{array}{c}\text { Testméretek } \\
\text { Measurements } \\
\mathrm{n}=100\end{array}$} & $\begin{array}{c}\text { Átlag } \\
\text { Mean }\end{array}$ & Min. & Max. & $\begin{array}{c}\text { KonBET \& } \\
\text { OvENDEN, 1982 }\end{array}$ & $\begin{array}{c}\text { Szórás } \\
\text { Variance }\end{array}$ & $\begin{array}{c}\text { Konfidencia } \\
\text { intervallum } \\
\text { Confidence interval } \\
(\alpha=0,05)\end{array}$ \\
\hline $\begin{array}{l}\text { Testtömeg }(\mathrm{g}) \\
\text { Weight }\end{array}$ & 17,4 & 7,0 & 37,0 & $17-40$ & 5,18 & $17,4 \pm 5,18$ \\
\hline $\begin{array}{l}\text { Testhossz }(\mathrm{mm}) \\
\text { Body length }\end{array}$ & 98,9 & 81,0 & 123,0 & $86-110$ & 9,79 & $98,9 \pm 9,79$ \\
\hline $\begin{array}{l}\text { Farokhossz (mm) } \\
\text { Tail length }\end{array}$ & 45,2 & 31,0 & 69,5 & $42-67$ & 7,47 & $45,2 \pm 7,47$ \\
\hline $\begin{array}{l}\text { Hátsó talp hossza (mm) } \\
\text { Hind foot length }\end{array}$ & 17,4 & 7,5 & 21,0 & $15,5-20$ & 1,49 & $17,4 \pm 1,49$ \\
\hline $\begin{array}{l}\text { Fülhossz (mm) } \\
\text { Ear length }\end{array}$ & 13,7 & 6,0 & 18,5 & - & 1,93 & $13,7 \pm 0,38$ \\
\hline
\end{tabular}

Az 1999-ben fogott alacsony egyedszám (8) miatt mikrohabitat vizsgálatot a faj tekintetében nem tudtam elvégezni.

A faj egyedei az összes csapdázott kisemlös (n=1645) 10,8\%-át tették ki. A fogott 177 példányból 161-nek (91\%) sikerült meghatározni az ivarát, közülük 29\% nősténynek (46pd), $71 \%$ (115 pd) hímnek bizonyult.
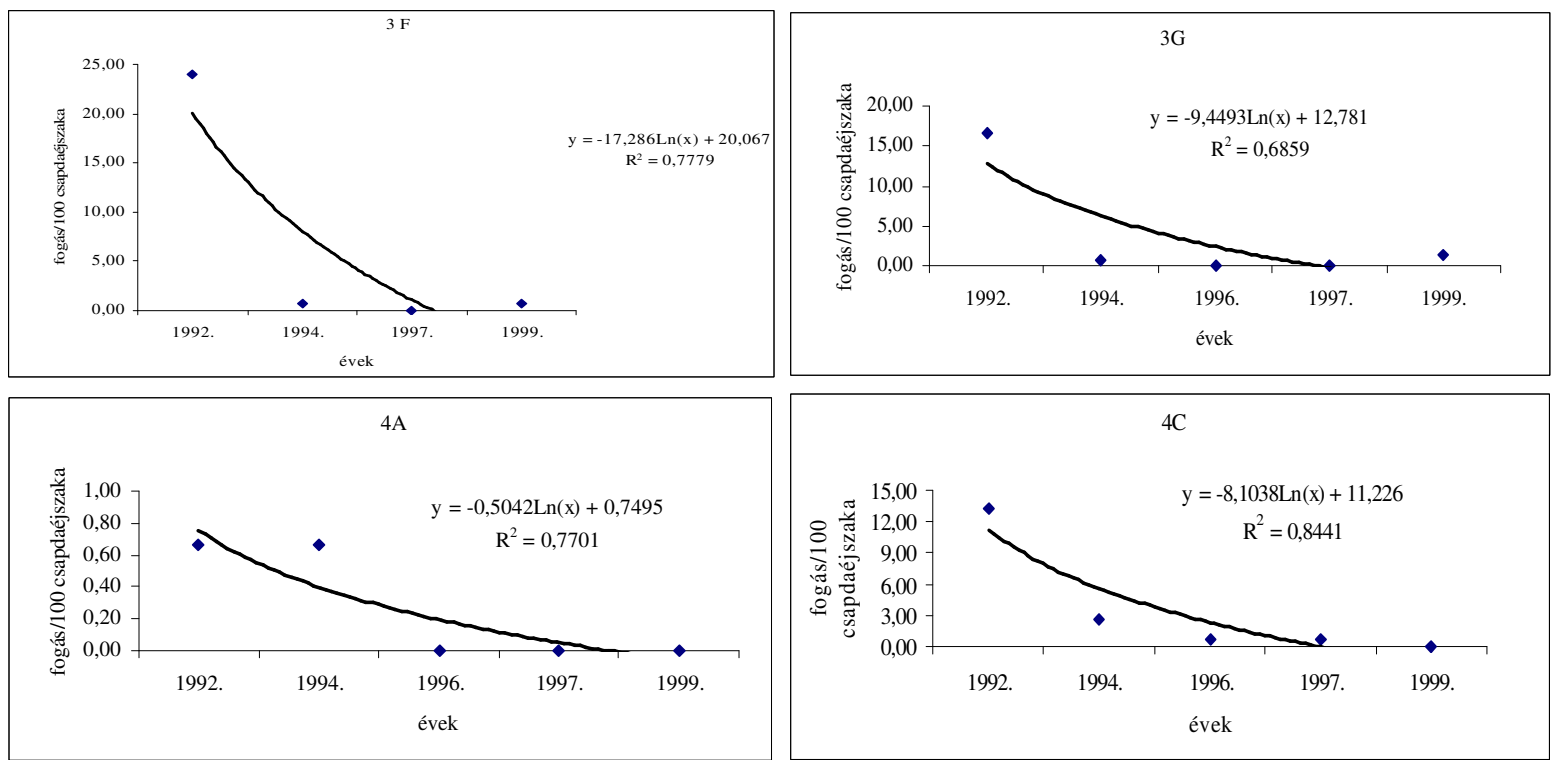

16. ábra: A vöröshátú erdeipocok egyedszámának változása 1992. és 1999. között Figure 21: Number changing of the Bank Vole between 1992 and 1999.

Az évek közötti dinamika tekintetében, mind a négy vizsgált erdősávban 1992-ben tapasztaltam denzitás maximumát, amelyet a vizsgálati időszak végéig elhúzódó összeomlás 
követett (21. ábra). A 100 csapdaéjszakára jutó fogásszám maximumok közül a 3F akácosban mutattam ki a legnagyobb értéket (24). Az állományváltozás trendje mind a négy esetben logaritmikus görbével volt jellemezhető.

120 megmért állat alapján az átlagos testtömeg évenkénti változását a 22. ábra szemlélteti, melyen feltüntettem az átlag standard hibáját is (SE). A legmagasabb értéket 1999-ben kaptam 23,1 grammal, a legalacsonyabb pedig az 1992. évi testtömeg (17,4 g).

\section{1. táblázat: A TUKEY HSD teszt eredményei a vöröshátú erdeipocok évenkénti átlagos testtömegének összehasonlításában. A kiemelt érték $p<0,05$ szinten szignifikáns különbséget jelez.}

Table 21: Results of the TUKEY HSD test for yearly average weight of the Bank Vole. The key values of $\mathrm{p}<0,05$ indicates significant difference.

\begin{tabular}{|l|c|c|c|}
\multicolumn{1}{|c|}{$\begin{array}{c}\text { Ýv } \\
\text { Year }\end{array}$} & $\mathbf{1 9 9 2}$ & $\mathbf{1 9 9 7}$ & $\mathbf{1 9 9 9}$ \\
\hline $\begin{array}{l}\text { Átlag \& Konfidencia } \\
\text { intervallum } \\
\text { Mean \& Confidence interval }\end{array}$ & $17,38 \pm 5,18$ & $19,19 \pm 4,62$ & $23,13 \pm 5,14$ \\
\hline $\mathbf{n}$ & 100 & 11 & 8 \\
\hline $\mathbf{1 9 9 2}$ & - & 0,15 & 0,01 \\
\hline $\mathbf{1 9 9 7}$ & - & - & 0,10 \\
\hline
\end{tabular}

A három évben tapasztalt átlagos testtömegek varianciaanalízis alapján eltérőnek bizonyultak (one-way ANOVA, $\mathrm{F}_{3,116}=4,77 \mathrm{p}<0,05$ ). Ezt ellenőrizve TUKEY HSD teszttel elmondható, hogy az 1999-ben mért átlagos testtömeg a vöröshátú erdeipocok esetében szignifikánsan nagyobb volt, mint az 1992-ben tapasztalt átlagos testtömeg (21. táblázat).

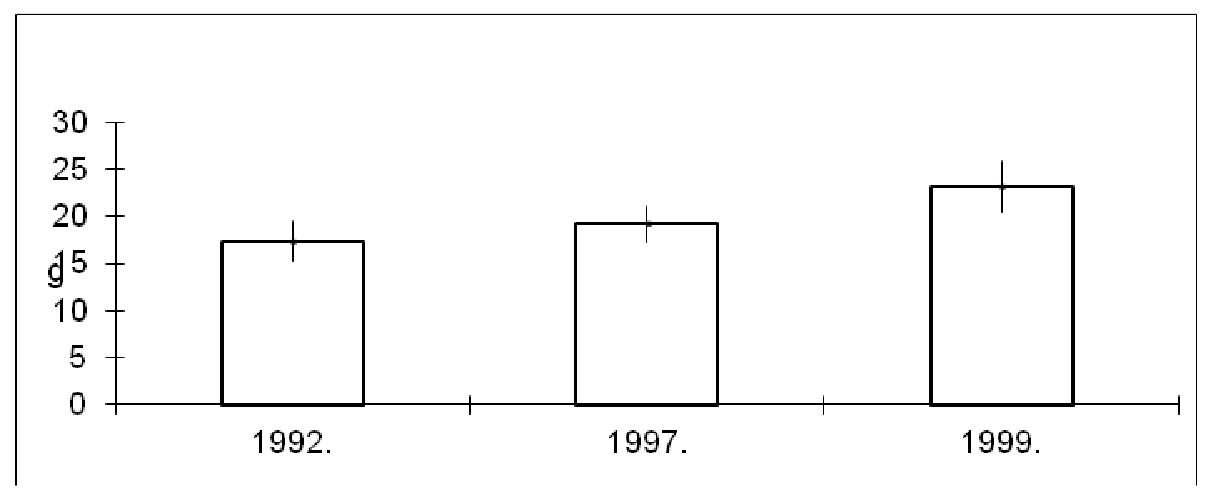

17. ábra: A vöröshátú erdeipocok évenkénti átlagos testtömeg értékei (n=120)

Figure 22: Yearly average weight of the Bank Vole $(n=120)$

A Lloyd-féle „foltosság” (patchiness) értékei alapján elmondható, hogy a 10 egyednél nagyobb példányszámban csapdázott habitatokban a vöröshátú erdeipocok állományok szegregáltságot mutattak (3F: 0,76, 3G: 0,63, 3I: 0,22, 4C: 0,49). 
4. 1. 10. Földi pocok - Pitymys subterraneus (DE SELYS-LONGHAMPS, 1836)

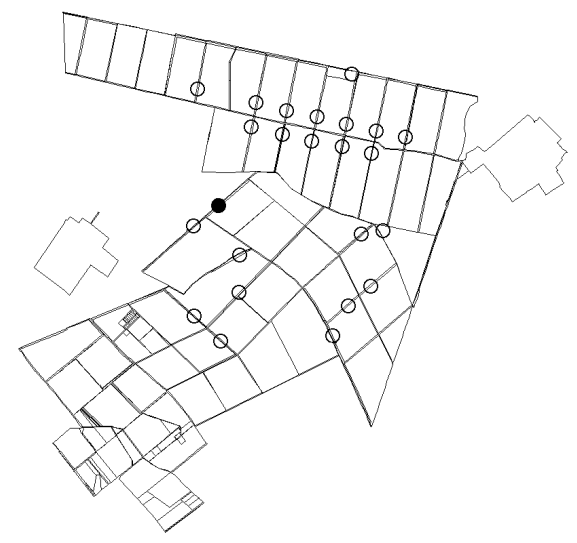

\section{6. térkép: A földi pocok előfordulása a LAJTA Projectben}

Map 17: Locations of the Pine Vole inthe LAJTA Project

Elterjedési területe Európára és Nyugat-Anatóliára korlátozódik. Franciaország atlanti partvidékétől a Fekete-tengerig él, hiányzik azonban a Földközi tenger medencéjének jelentős részéből. Északon Észtország, ill. Szentpétervár környéke jelenti az elterjedési terület határát, míg keleten a Don folyóig fordul elő (MITCHELL-JONES et al., 1999).

A földi pocok a vizsgált 24 erdősávból 1-ben (4\%) fordult elő (17. térkép). A faj egyede (1pd) az összes csapdázott kisemlős $(\mathrm{n}=1645)$,1\%-át tette ki.

\subsubsection{Mezei pocok - Microtus arvalis (PALLAS, 1778)}

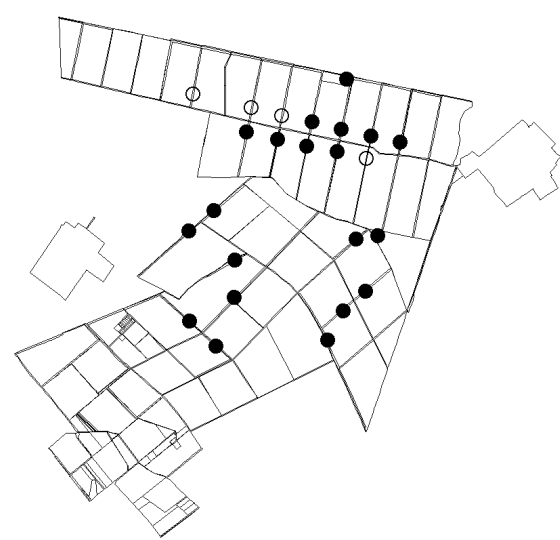

\section{7. térkép: A mezei pocok előfordulása a LAJTA Projectben}

Map 18: Locations of the Common Vole in the LAJTA Project

Európában endemikus faj. Általánosan elterjedt Franciaország atlanti parvidékétől Oroszország középső területeiig. Hiányzik a Mediterráneum jelentős részéről, a Britszigetekről. Elszigetelt populációja él az Ibériai-félszigeten (MITCHELL-JONES et al., 1999). Földrajzi változatosság tekintetében több mint 20 alfaját írták le (MITCHELL-JONES et al., 1999).

A mezei pocok a vizsgált 24 erdősávból 19-ben (79\%) fordult elö (18. térkép). 
22. táblázat: A mezei pocok biometriai jellemzői

Table 22: Biometric features of the Common Vole

\begin{tabular}{|l|c|c|c|c|c|c|}
\hline \multicolumn{1}{|c|}{$\begin{array}{c}\text { Testméretek } \\
\text { Measurements } \\
\mathrm{n}=108\end{array}$} & $\begin{array}{c}\text { Átlag } \\
\text { Mean }\end{array}$ & Min. & Max. & $\begin{array}{c}\text { KonBET \& } \\
\text { OvENDEN, 1982 }\end{array}$ & $\begin{array}{c}\text { Konfírís } \\
\text { Variance }\end{array}$ & $\begin{array}{c}\text { Koncia } \\
\text { intervallum } \\
\text { Confidence interval } \\
(\alpha=0,05)\end{array}$ \\
\hline $\begin{array}{l}\text { Testtömeg }(\mathrm{g}) \\
\text { Weight }\end{array}$ & 24,5 & 4,5 & 50,0 & $13,5-51$ & 8,97 & $24,5 \pm 1,65$ \\
\hline $\begin{array}{l}\text { Testhossz }(\mathrm{mm}) \\
\text { Body length }\end{array}$ & 105,0 & 17,0 & 137,0 & $85-125$ & 15,49 & $105,03 \pm 2,83$ \\
\hline $\begin{array}{l}\text { Farokhossz (mm) } \\
\text { Tail length }\end{array}$ & 33,5 & 22,0 & 68,0 & $25-46$ & 5,77 & $33,5 \pm 0,99$ \\
\hline $\begin{array}{l}\text { Hátsó talp hossza }(\mathrm{mm}) \\
\text { Hind foot length }\end{array}$ & 16,2 & 7,0 & 18,0 & $13,5-18$ & 2,18 & $16,2 \pm 0,38$ \\
\hline $\begin{array}{l}\text { Fülhossz }(\mathrm{mm}) \\
\text { Ear length }\end{array}$ & 12,7 & 9,0 & 23,0 & - & 2,24 & $12,7 \pm 0,42$ \\
\hline
\end{tabular}

Az 1999-ben végzett mikrohabitat vizsgálat alapján a faj a vizsgált 23 mikrohabitatból csak 12-ben $(52 \%)$ fordult elő. A mikrohabitat preferenciára irányuló tapasztalati és elméleti gyakoriság illesztés $\chi^{2}$ próbával elvégzett illeszkedésvizsgálata alapján $\left(\chi^{2}=46,32 p<0,01\right.$, $\mathrm{df}=22$ ) a populáció egyedeinek mikrohabitatok közti eloszlása nem egyenletes. A fogott egyedek 19\%-a a 4C kvadrát III. növényzeti egységéből (angolperje, közönséges tarackbúza, közönséges aszat és betyárkóró) került elő (23. ábra), ez a faj által legkedveltebb mikrohabitat. További, gyakran használt növényzeti egységek még a 4C-V. (fagyal cserjeszint, fedél rozsnok gyepszint), 4C-IV. (fagyal cserjeszint, fedél rozsnok és közönséges tarackbúza gyepszint), 3G-IV. (fagyal cserjeszint, csomós ebír, franciaperje, réti perje, közönséges aszat és angolperje), 4A-II. (angolperje és közönséges tarackbúza gyepszint). Feltűnő, hogy a zárt akácerdőben lévő $3 \mathrm{~F}$ kvadrát mikrohabitatjait egy kivétellel egyáltalán nem látogatta a mezei pocok, valamint, hogy az egyik tipikus élőhelyeként ismert lucernásban (4A-V.) is csak alacsony egyedszámban fordult elő. Nem látogatta a kukoricatáblát (4C-VII.) és a tárcsázott borsótarlót (4C-I.) sem.

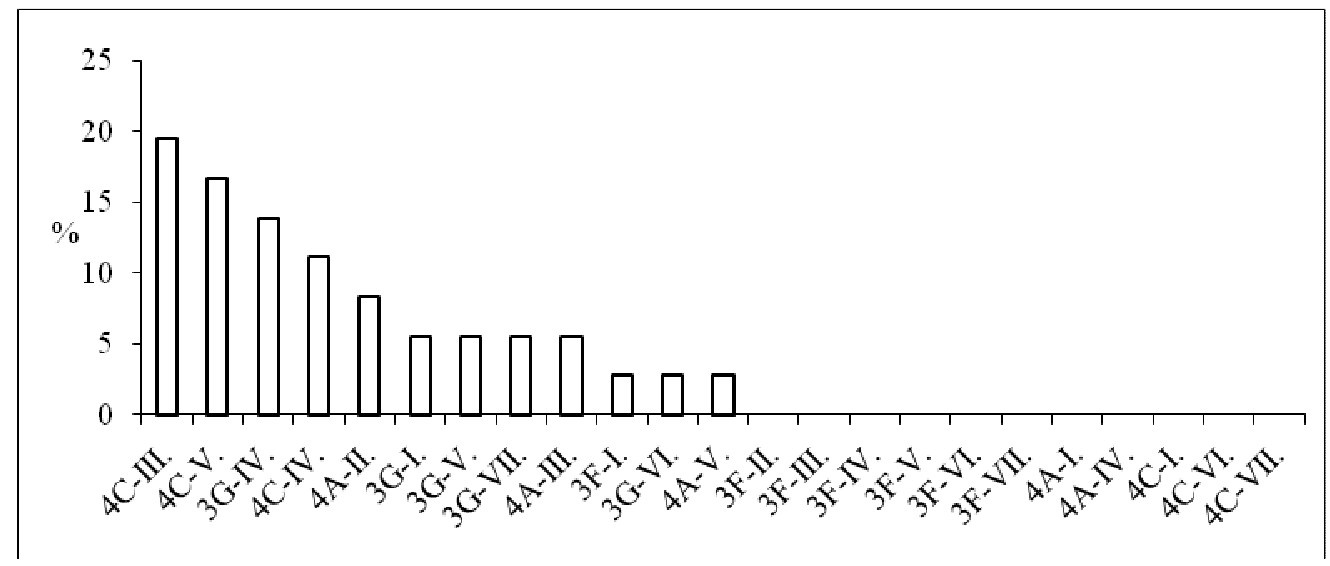

18. ábra: A mezei pocok mikrohabitat használata $(n=43)$

Figure 23: Microhabitat use of the Common Vole

A faj egyedei az összes csapdázott kisemlös (n=1645) 27,2\%-át tették ki. A fogott 448 példányból 409-nek (91\%) sikerült meghatározni az ivarát, közülük 24\% nősténynek (97pd), 76\% hímnek (312 pd) bizonyult. 
Az egy vegetációs perióduson belüli dinamikát vizsgálva (24. ábra) megállapítható, hogy 1999-ben a négy kvadrátból kettőben augusztusi (3F és 3G), kettőben pedig szeptemberi (4A és 4C) maximum jelentkezett.

Az alacsony, több esetben 0 fogásszám miatt a fogásszám havonkénti dinamikáját nem állt módomban vizsgálni.

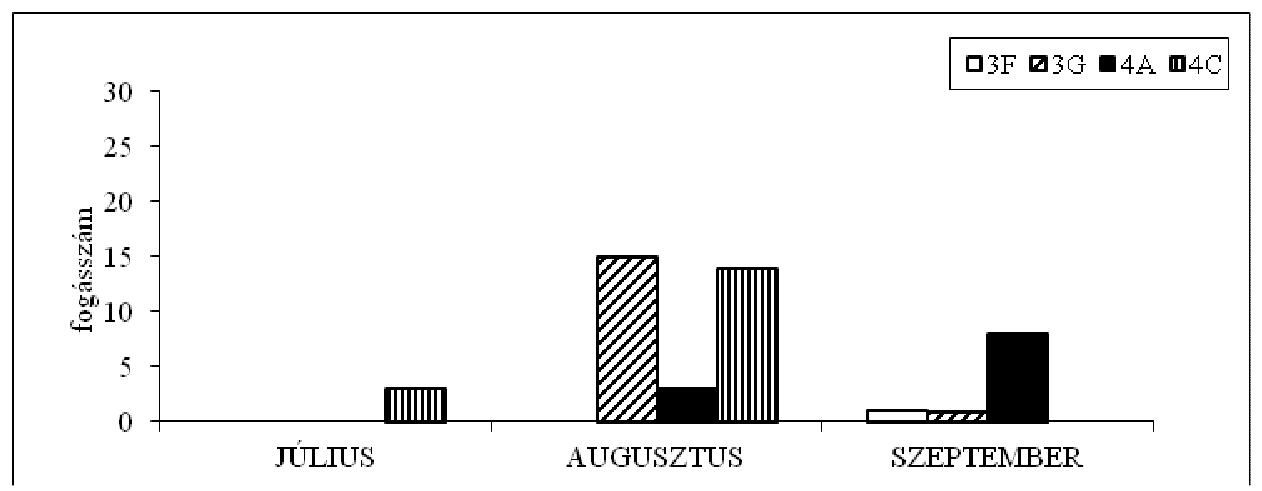

19. ábra: A mezei pocok dinamikája 1999-ben $(n=43)$

Figure 24: Dinamics of the Common Vole in $1999(n=43)$

Az évek közötti dinamika tekintetében -eltérően a többi rágcsáló fajtól- 3 vizsgált erdősávban két helyi maximumot mutattam ki (1992. és 1997.), mely a populáció intenzív gradációs jellegét hangsúlyozza (25. ábra). A legnagyobb, 100 csapdaéjszakára jutó fogásszám értéket a 4C erdősávban tapasztaltam $(16,67)$. Az átlagosan legkisebb fogási értékekkel jellemezhető 3F akácosban mutattam ki a legstabilabb populáció jelenlétét, innen származik a négy élőhely relatív minimumának legnagyobb értéke is $(1999 .: 0,67)$. A denzitás változás trendjét a 3F erdősáv esetében lineáris regresszió írja le $\left(\mathrm{r}^{2}=0,6\right)$.

A Lloyd-féle „foltosság” (patchiness) értékei alapján elmondható, hogy a 10 egyednél nagyobb példányszámban csapdázott habitatokban a mezei pocok állományok 8 esetben szegregáltságot, 7-ben aggregáltságot mutattak (23. táblázat). Egy esetben eloszlásuk véletlenszerü volt, a foltosság denzitásfüggésére vonatkozó trendet nem sikerült kimutatni.
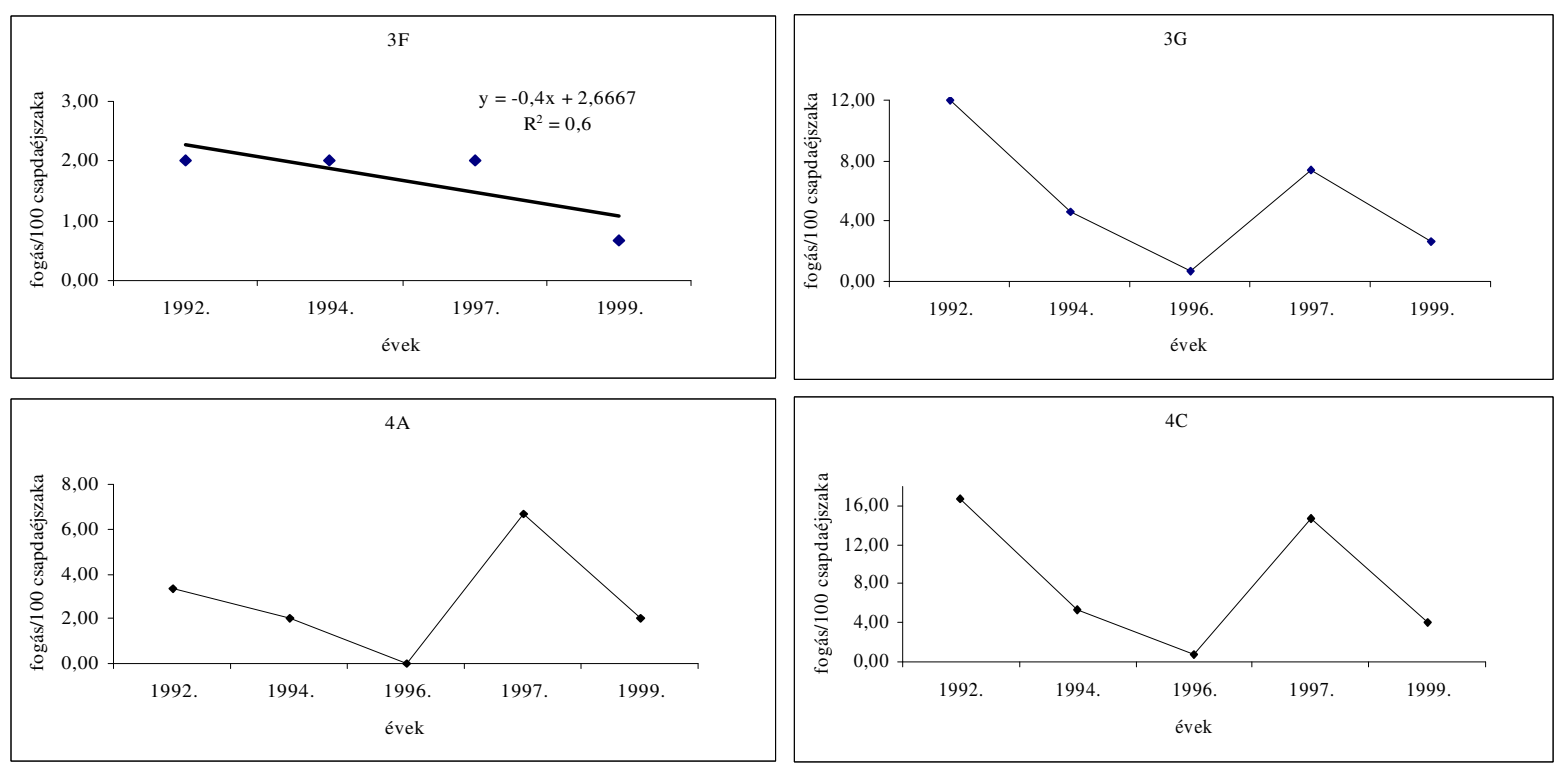

20. ábra: A mezei pocok egyedszámának változása 1992 és 1999 között

Figure 25: Changes in numbers of the Common Vole from 1992. to 1999. 


\section{3. táblázat: A mezei pocok populációk Lloyd-féle foltosság értékei}

Table 23: Lloyd's patchiness values of the common vole populations

\begin{tabular}{|l|c|c|c|}
\hline $\begin{array}{c}\text { Erdösáv } \\
\text { Forest belt }\end{array}$ & $\mathbf{1 9 9 2}$ & $\mathbf{1 9 9 4}$ & $\mathbf{1 9 9 7}$ \\
\hline $\mathbf{3 G}$ & 0,91 & - & 0,81 \\
\hline $\mathbf{3 H}$ & 1,36 & 1,33 & - \\
\hline $\mathbf{3 I}$ & 0,00 & 1,96 & - \\
\hline $\mathbf{4 A}$ & - & - & 0,98 \\
\hline 4C & 0,78 & - & 1,62 \\
\hline $\mathbf{7 0 B}$ & 1,62 & - & - \\
\hline 69F & - & - & - \\
\hline $\mathbf{6 9 E}$ & 0,58 & - & 1,09 \\
\hline $\mathbf{7 0 A}$ & 1,00 & - & 0,91 \\
\hline $\mathbf{7 0 C}$ & 1,36 & - & - \\
\hline 68D & - & - & 0,87 \\
\hline
\end{tabular}

234 megmért állat alapján az átlagos testtömeg évenkénti változását a 26. ábra szemlélteti, melyen feltüntettem az átlag standard hibáját is (SE). A legmagasabb értéket 1999-ben kaptam 28,7 grammal, a legalacsonyabb pedig az 1997. évi testtömeg (22,2 g).

A három évben tapasztalt átlagos testtömegek varianciaanalízis alapján eltérőnek bizonyultak (one-way ANOVA, $\mathrm{F}_{3,144}=7,6, \mathrm{p}<0,05$ ). Ezt ellenörizve TUKEY HSD teszttel, az 1999-ben mért átlagos testtömeg a mezei pocok esetében szignifikánsan nagyobb volt mind az 1992-ben, mind az 1997-ben tapasztaltnál (24. táblázat).

24. táblázat: A TuKey HSD teszt eredményei a mezei pocok évenkénti átlagos testtömegének összehasonlításában. A kiemelt értékek $p<0,05$ szinten szignifikáns különbséget jeleznek.

Table 24: Results of the TUKEY HSD test for yearly average weight of the Common Vole. The key data of $\mathrm{p}<0,05$ indicates significant difference.

\begin{tabular}{|l|c|c|c|}
\hline \multicolumn{1}{|c|}{$\begin{array}{c}\text { Eear } \\
\text { Year }\end{array}$} & $\mathbf{1 9 9 2}$ & $\mathbf{1 9 9 7}$ & $\mathbf{1 9 9 9}$ \\
\hline $\begin{array}{l}\text { Átlag \& Konfidencia } \\
\text { intervallum } \\
\text { Mean \& Confidence interval }\end{array}$ & $24,5 \pm 8,96$ & $22,21 \pm 7,83$ & $28,72 \pm 8,69$ \\
\hline $\mathbf{n}$ & 114 & 80 & 39 \\
\hline $\mathbf{1 9 9 2}$ & - & 0,15 & 0,01 \\
\hline $\mathbf{1 9 9 7}$ & - & - & 0,10 \\
\hline
\end{tabular}




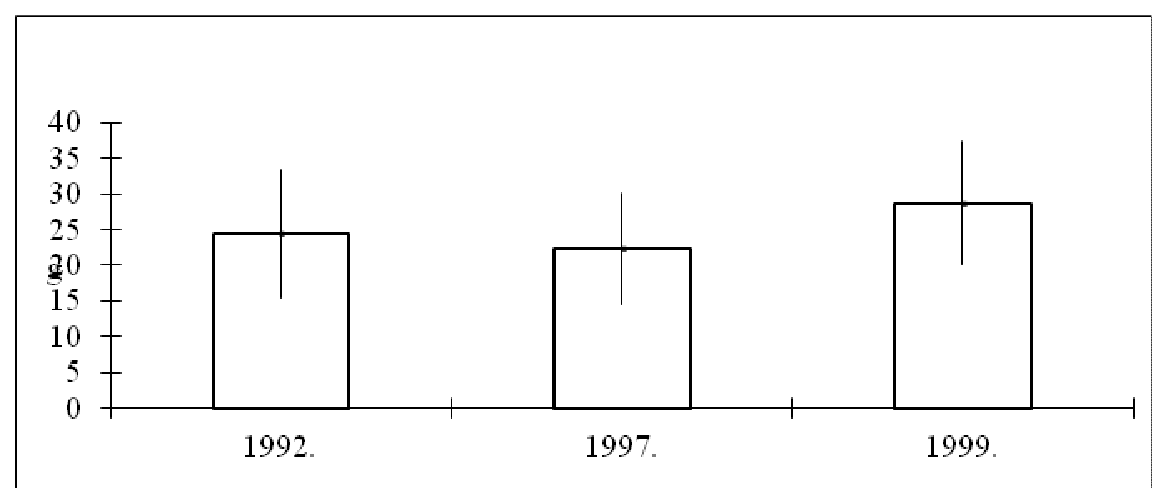

21. ábra: A mezei pocok átlagos testtömeg értékei $(n=234)$

Figure 26: Average weight of the Common Vole $(n=234)$

\subsection{Az erdősávok kisemlős közösségeinek szerkezete}

\subsubsection{Fajszám és egyedsürüség}

A 27. ábrán a vizsgált erdősávok kisemlős közösségeinek fajszám és 100 csapdaéjszakára jutó egyedszám értékeit mutatom be az egyes vizsgálati években. Mindkét jellemző tekintetében az 1992-es és 1999-es év eredményei adták a legnagyobb értékeket. Egy három, ill. négy napos csapdázás során a legtöbb faj (7) a 1999 szeptemberében a 3G erdősávból és 1992 júliusában a 3I erdősávból került elő.
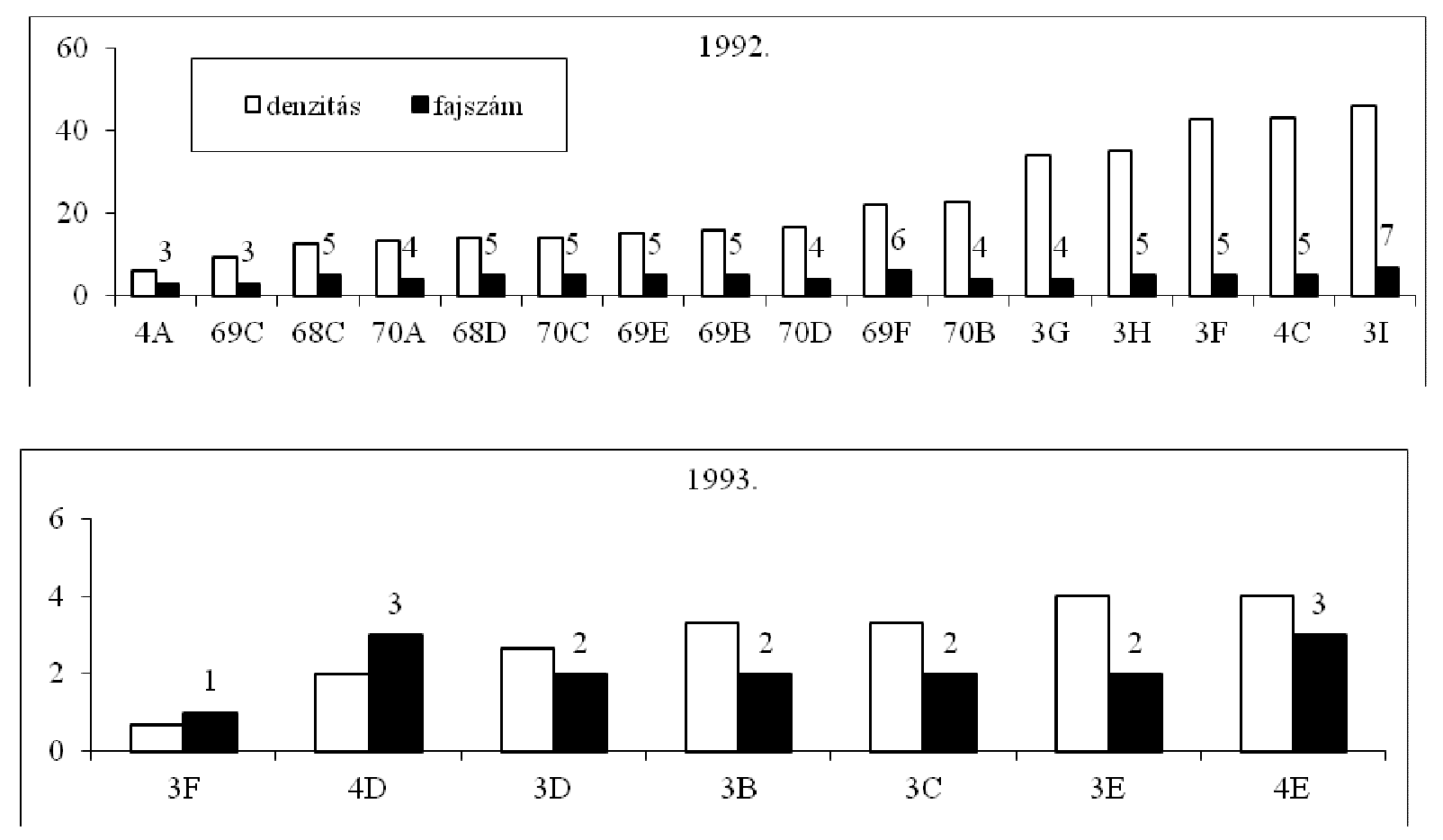

22. ábra: A kisemlős közösségek denzitás és fajszám értékei

Figure 27: Density and species number of the small mammal communities 

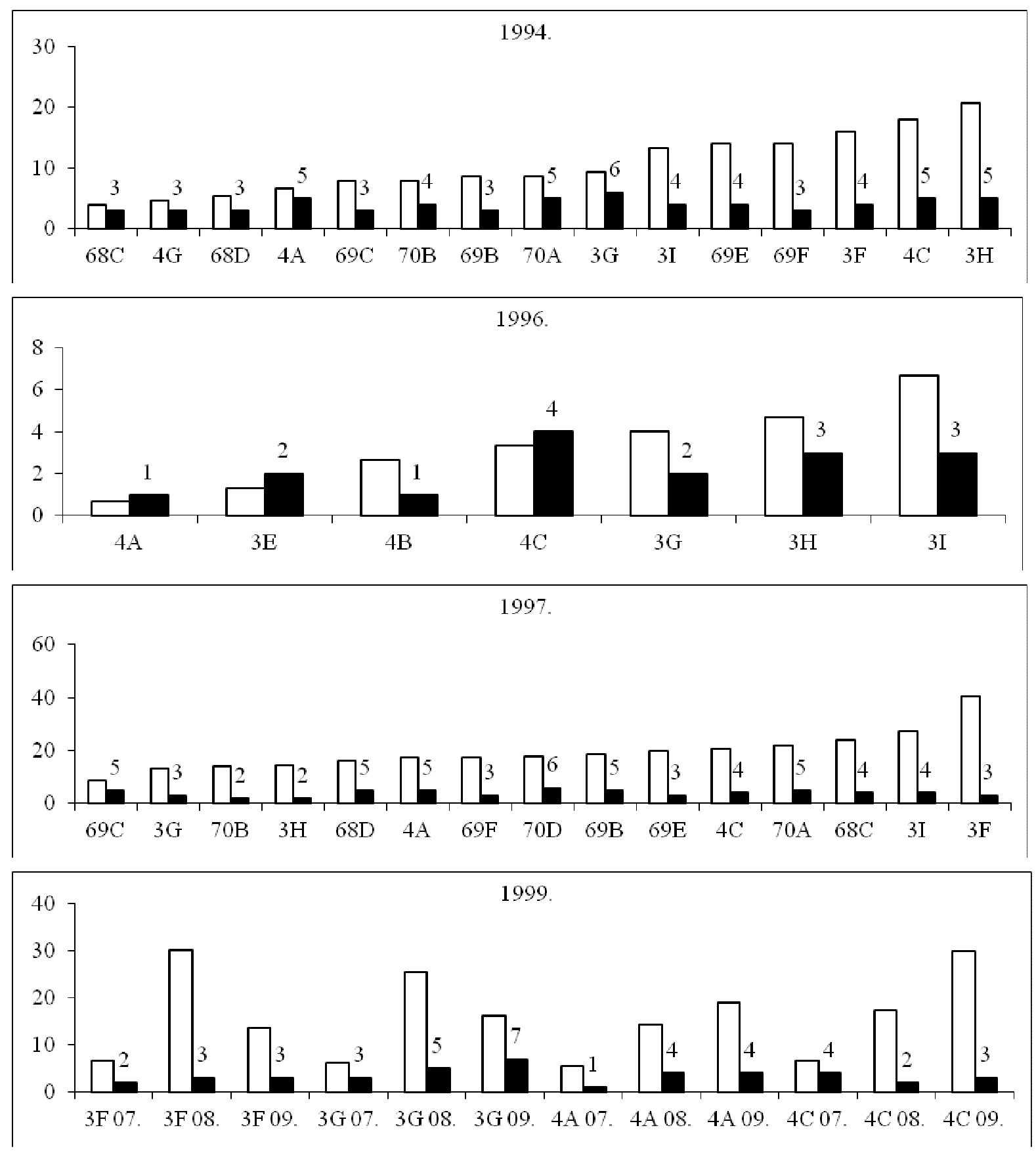

27. ábra (folytatás): A kisemlős közösségek denzitás (fehér) és fajszám (fekete) értékei

Figure 27 (cont.): Density (white) and species number (black) of the small mammal communities

Csak egy faj jelenlétét sikerült kimutatni 1993. július hónapban a 3F, 1996. júliusban a 4A és 4B, 1999 júliusában pedig a 4A erdősávból.

A 100 csapdaéjszakára jutó egyedszám legnagyobb értéke (43,33) 1992-ben a 3I jelü erdősávra volt jellemző, a minimumot pedig 1993-ban, a 3F akácosban mutattam ki $(0,67)$. Az ábrák alapján elmondható, hogy az 1993-as és az 1996-os években a közösségeket alacsony fajszám és denzitás értékek jellemezték, míg a másik négy évben több, hasonló nagyságrendü kisemlős faj alkotta a létszámukban is megszaporodó együtteseket.

A fajkészlet és annak vizsgálati évek közti változása alapvető információval szolgál az élőhelyek közösségeinek stabilitásáról. A fajkészlet és a fajszám változását szemléltető 25. táblázatban azokat az erdősávokat tüntettem fel, melyekben a vizsgálati időszak során 
legalább három különbözö évben végeztem csapdázást. A táblázatból kitünik, hogy a fent említett 3G erdősáv fajkészlete 1999-ben 8 fajból állt, tehát a szeptemberben kimutatott 7 faj mellett augusztusban a mezei pocok előfordulása is beigazolódott. A táblázatban szereplő 13 erdősávból egyben sem volt állandó a fajkészlet.

A Mosonszolnok 3F erdősávban az első évben kimutatott 5 fajból 1993-ra csupán a sárganyakú erdeiegér maradt meg. A következő évben a mezei cickány kivételével ismét sikerült kimutatni az először csapdázott fajokat. 1997-re eltünt a vöröshátú erdeipocok is, a következő évben azonban ismét megjelent.

A Mosonszolnok 3G erdősáv fajkészlete kezdetben bövülést mutatott a közönséges erdeiegér, a törpecickány és a törpeegér megjelenésével, majd két év erőteljes csökkenése következett be, amikor a közönséges erdeiegér, a mezei pocok és az erdei cickány kivételével minden faj eltünt. 1999-re azonban ismét megjelent mind a hét korábban kimutatott faj, sőt a sávból a güzüegér is előkerült.

A Mosonszolnok 3H erdősáv közössége az első két évben stabilan 5 fajból állt, amely 1996-ra az erdei cickány és a vöröshátú erdeipocok, majd 1997-re a sárganyakú erdeiegér eltünésével 3-ra, ill. 2-re csökkent.

A Mosonszolnok 3I erdősávban 1992-ben 7 fajt találtam. 1994-re a mezei és az erdei cickány, valamint a törpeegér tünt el közülük, később pedig a mezei pocok hiányzott.

A Mosonszolnok 4A erdősáv közössége kezdetben 3 fajból állt, mely fajszám 1994-re a törpecickány és a közönséges erdeiegér megjelenésével nőtt. 1996-ban egy drasztikus csökkenés után csak az utóbbi faj volt kimutatható, később azonban a güzüegér és az erdei cickány megjelenésével párhuzamosan, a vöröshátú erdeipocok kivételével minden korábbi faj visszatért.

A Mosonszolnok 4C erdősáv közössége fajszám tekintetében mindvégig stabil volt (4, ill. 5 faj). Fajkészletében azonban a cickányfélék és a güzüegér alkalmi megjelenése és a vöröshátú erdeipocok eltünése okozott változásokat.

A Jánossomorja 68C erdősávban a három stabil faj mellett a mezei pocok és a mezei cickány jelenléte és eltünése volt kimutatható.

A Jánossomorja 68D erdősáv közössége kezdetben 5 fajból állt, amely 1994-re a mezei pocok és az erdei cickány eltünésével 3-ra csökkent. 1997-ben azonban az erdei cickány ismét megjelent.

A Jánossomorja 69B erdősáv helyzete a fentihez hasonló, azzal az eltéréssel, hogy a mezei pocok helyett a vöröshátú erdeipocok eltünése jelentett benne változást.

A Jánossomorja 69C erdősávban kezdetben 3 faj volt jelen, amely 1997-re a vöröshátú erdeipocok és a földipocok megjelenésével 5-re bővült.

A Jánossomorja 69E erdősáv 1992-ben kimutatott 5 fajából 1994-re az erdei cickány tünt el, 1997-re pedig a sárganyakú erdeiegér és a vöröshátú erdeipocok.

A Jánossomorja 69F erdősávban kezdetben 6 fajból álló, fajgazdag közösséget találtam, amelyből az évek során a Soricidák és a vöröshátú erdeipocok eltűntek.

A Jánossomorja 70A erdősávban 1994-ben 1992-höz képest fajszám növekedés következett be, amely a vöröshátú erdeipocok és a törpecickány -erdei cickány eltünését kiegyensúlyozómegjelenésének köszönhető. 1997-re a fajszám nem változott, azonban újabb két faj jelent meg (törpeegér és güzüegér), ill. tünt el (vöröshátú erdeipocok és törpecickány).

A Jánossomorja 70B erdősávban 1992-ben 4 faj fordult elő, melyek közül 1993-ra az erdei cickány eltünt. Ezzel párhuzamosan megjelent a vöröshátú erdeipocok. 1996-ra a fajszám kettőre csökkent, csupán a közönséges erdeiegér és a mezei pocok volt kimutatható. 
25. táblázat: A fajszám (s) és a fajkészlet alakulása a LAJTA Project erdősávjaiban

Table 25: Species number (s) and dominance of small mammals in the LAJTA Project's forest belts

\begin{tabular}{|c|c|c|c|c|c|c|c|c|c|c|c|c|}
\hline & \multicolumn{2}{|l|}{1992} & \multicolumn{2}{|c|}{1993} & \multicolumn{2}{|c|}{1994} & \multicolumn{2}{|l|}{1996} & \multicolumn{2}{|l|}{1997} & \multicolumn{2}{|l|}{1999} \\
\hline & fajkészlet & $\mathrm{s}$ & fajkészlet & $\mathrm{s}$ & fajkészlet & $\mathrm{s}$ & fajkészlet & $\mathrm{s}$ & fajkészlet & $\mathrm{s}$ & fajkészlet & $\mathrm{s}$ \\
\hline \multirow[t]{5}{*}{$3 \mathrm{~F}$} & APOFLA & 5 & APOFLA & 1 & APOFLA & 4 & & & APOFLA & 3 & APOFLA & 4 \\
\hline & APOSYL & & & & APOSYL & & & & APOSYL & & APOSYL & \\
\hline & CLEGLA & & & & CLEGLA & & & & MICARV & & CLEGLA & \\
\hline & CROLEU & & & & MICARV & & & & & & MICARV & \\
\hline & MICARV & & & & & & & & & & & \\
\hline \multirow[t]{8}{*}{$3 \mathrm{G}$} & APOFLA & 4 & & & APOFLA & 6 & APOSYL & 2 & APOSYL & 3 & APOFLA & 8 \\
\hline & CLEGLA & & & & APOSYL & & MICARV & & MICARV & & APOSYL & \\
\hline & MICARV & & & & CLEGLA & & & & SORARA & & CLEGLA & \\
\hline & SORARA & & & & MICARV & & & & & & MICARV & \\
\hline & & & & & SORMIN & & & & & & SORARA & \\
\hline & & & & & MICMIN & & & & & & SORMIN & \\
\hline & & & & & & & & & & & MICMIN & \\
\hline & & & & & & & & & & & MUSSPI & \\
\hline \multirow[t]{5}{*}{$3 \mathrm{H}$} & APOFLA & 5 & & & APOFLA & 5 & APOFLA & 3 & APOSYL & 2 & & \\
\hline & APOSYL & & & & APOSYL & & APOSYL & & MICARV & & & \\
\hline & CLEGLA & & & & CLEGLA & & MICARV & & & & & \\
\hline & MICARV & & & & MICARV & & & & & & & \\
\hline & SORARA & & & & SORARA & & & & & & & \\
\hline \multirow[t]{7}{*}{$3 \mathrm{I}$} & APOFLA & 7 & & & APOFLA & 4 & APOFLA & 3 & APOFLA & 4 & & \\
\hline & APOSYL & & & & APOSYL & & APOSYL & & \begin{tabular}{|l|} 
APOSYL \\
\end{tabular} & & & \\
\hline & CLEGLA & & & & CLEGLA & & CLEGLA & & CLEGLA & & & \\
\hline & CROLEU & & & & MICARV & & & & \begin{tabular}{|l|} 
MICARV \\
\end{tabular} & & & \\
\hline & MICARV & & & & & & & & & & & \\
\hline & SORARA & & & & & & & & & & & \\
\hline & MICMIN & & & & & & & & & & & \\
\hline \multirow[t]{5}{*}{$4 \mathrm{~A}$} & APOFLA & 3 & & & APOFLA & 5 & APOSYL & 1 & APOFLA & 5 & APOFLA & 5 \\
\hline & CLEGLA & & & & APOSYL & & & & APOSYL & & APOSYL & \\
\hline & MICARV & & & & CLEGLA & & & & MICARV & & MICARV & \\
\hline & & & & & MICARV & & & & SORARA & & SORARA & \\
\hline & & & & & SORMIN & & & & MUSSPI & & SORMIN & \\
\hline \multirow[t]{7}{*}{$4 \mathrm{C}$} & APOFLA & 5 & & & APOFLA & 5 & APOFLA & 4 & APOSYL & 4 & APOFLA & 5 \\
\hline & APOSYL & & & & APOSYL & & APOSYL & & CLEGLA & & APOSYL & \\
\hline & 1992 & & 1993 & & 1994 & & 1996 & & 1997 & & 1999 & \\
\hline & fajkészlet & $\mathrm{s}$ & fajkészlet & $\mathrm{s}$ & fajkészlet & $\mathrm{s}$ & fajkészlet & $\mathrm{s}$ & fajkészlet & $\mathrm{s}$ & fajkészlet & $\mathrm{s}$ \\
\hline & CLEGLA & & & & CLEGLA & & $\begin{array}{l}\text { CLEGLA } \\
\end{array}$ & & \begin{tabular}{|l|} 
MICARV \\
\end{tabular} & & MICARV & \\
\hline & MICARV & & & & CROLEU & & MICARV & & MUSSPI & & SORARA & \\
\hline & SORARA & & & & MICARV & & & & & & MUSSPI & \\
\hline \multirow[t]{2}{*}{$68 \mathrm{C}$} & APOFLA & 5 & & & APOFLA & 3 & & & \begin{tabular}{|l} 
APOFLA \\
\end{tabular} & 4 & & \\
\hline & APOSYL & & & & APOSYL & & & & APOSYL & & & \\
\hline
\end{tabular}




\begin{tabular}{|c|c|c|c|c|c|c|c|c|c|c|c|c|}
\hline & CLEGLA & & & & CLEGLA & & & & CLEGLA & & & \\
\hline & CROLEU & & & & & & & & MICARV & & & \\
\hline & MICARV & & & & & & & & & & & \\
\hline \multirow[t]{5}{*}{$68 \mathrm{D}$} & APOFLA & 5 & & & APOFLA & 3 & & & APOFLA & 4 & & \\
\hline & APOSYL & & & & APOSYL & & & & APOSYL & & & \\
\hline & CLEGLA & & & & CLEGLA & & & & MICARV & & & \\
\hline & MICARV & & & & & & & & SORARA & & & \\
\hline & SORARA & & & & & & & & & & & \\
\hline \multirow[t]{5}{*}{$69 B$} & APOFLA & 5 & & & APOFLA & 3 & & & APOFLA & 4 & & \\
\hline & APOSYL & & & & APOSYL & & & & APOSYL & & & \\
\hline & CLEGLA & & & & MICARV & & & & MICARV & & & \\
\hline & MICARV & & & & & & & & SORARA & & & \\
\hline & SORARA & & & & & & & & & & & \\
\hline \multirow[t]{5}{*}{$69 \mathrm{C}$} & APOFLA & 3 & & & APOFLA & 3 & & & APOFLA & 5 & & \\
\hline & APOSYL & & & & APOSYL & & & & APOSYL & & & \\
\hline & MICARV & & & & MICARV & & & & CLEGLA & & & \\
\hline & & & & & & & & & MICARV & & & \\
\hline & & & & & & & & & PYTSUB & & & \\
\hline \multirow[t]{5}{*}{$69 \mathrm{E}$} & APOFLA & 5 & & & APOFLA & 4 & & & APOSYL & 3 & & \\
\hline & APOSYL & & & & APOSYL & & & & MICARV & & & \\
\hline & CLEGLA & & & & CLEGLA & & & & SORARA & & & \\
\hline & MICARV & & & & MICARV & & & & & & & \\
\hline & SORARA & & & & & & & & & & & \\
\hline \multirow[t]{6}{*}{$69 \mathrm{~F}$} & APOFLA & 6 & & & APOFLA & 3 & & & APOFLA & 4 & & \\
\hline & APOSYL & & & & APOSYL & & & & APOSYL & & & \\
\hline & CLEGLA & & & & MICARV & & & & MICARV & & & \\
\hline & MICARV & & & & & & & & MUSSPI & & & \\
\hline & SORARA & & & & & & & & & & & \\
\hline & SORMIN & & & & & & & & & & & \\
\hline \multirow[t]{5}{*}{$70 \mathrm{~A}$} & APOFLA & 4 & & & APOFLA & 5 & & & APOFLA & 5 & & \\
\hline & APOSYL & & & & APOSYL & & & & APOSYL & & & \\
\hline & MICARV & & & & CLEGLA & & & & MICARV & & & \\
\hline & SORARA & & & & MICARV & & & & MICMIN & & & \\
\hline & & & & & SORMIN & & & & MUSSPI & & & \\
\hline \multirow[t]{4}{*}{$70 \mathrm{~B}$} & APOFLA & 4 & APOFLA & 4 & & & APOSYL & 2 & & & & \\
\hline & APOSYL & & APOSYL & & & & MICARV & & & & & \\
\hline & MICARV & & CLEGLA & & & & & & & & & \\
\hline & SORARA & & MICARV & & & & & & & & & \\
\hline
\end{tabular}

\subsubsection{Dominancia viszonyok}

A kisemlős közösségek dominancia viszonyai az évek során és egy vegetációs perióduson belül is jelentős eltéréseket mutattak. Megállapítható, hogy a vizsgálati területen előforduló közösségeknek négy meghatározó, domináns és szubdomináns faja van: a közönséges erdeiegér, a sárganyakú erdeiegér, a vöröshátú erdeipocok és a mezei pocok. Mellettük 
akcesszórikus fajként jelenik meg az erdei cickány és a törpeegér. A közösségek ritka fajai: a törpecickány, a mezei cickány, a güzüegér, a közönséges hörcsög és a földipocok.

A következőkben azon erdősávok kisemlős közösségeit elemzem részletesen, melyekben a vizsgálati időszak alatt legalább három különböző évben végeztem csapdázásokat.

\section{A Mosonszolnok 3F erdősáv kisemlős közössége}

1992-ben a közösség domináns faja a vöröshátú erdeipocok volt. 1993-ban csupán egyetlen kisemlöst, 1pd sárganyakú erdeiegeret fogtam a területen. 1994-től kezdődően, az akkor domináns közönséges erdeiegér és az 1992-höz képest megritkult vöröshátú erdeipocok fokozatos visszaszorulását mutattam ki, a sárganyakú erdeiegér dominanciájának növekedése mellett (28a ábra). Feltünő, hogy a zárt akácos szegélyét képező 3F erdősávban a mezei pocok nem jelentkezik markáns közösségalkotó fajként.

\section{A Mosonszolnok 3G erdősáv kisemlős közössége}

1992-ben a közösség domináns faja a vöröshátú erdeipocok volt. 1994-ben a korábban szubdomináns mezei pocok volt az uralkodó faj, és megjelent az erdősávban a közönséges erdeiegér. A következő években e két faj versengését tapasztaltam, mely 1996-ban a közönséges erdeiegér, 1997-ben pedig a mezei pocok dominanciáját eredményezte. 1999-re ismét számottevő lett a sárganyakú erdeiegér aránya (28b ábra).

\section{A Mosonszolnok 3H erdősáv kisemlős közössége}

A közösség domináns faja 1992. és 1996. között a mezei pocok, mellette a sárganyakú és a közönséges erdeiegér népessége jelentős. 1997-re a közösség szerkezete átrendeződik, a közönséges erdeiegér válik dominánssá, a korábban ritka fajok jelenlétét nem sikerül kimutatni (28c ábra).

\section{A Mosonszolnok 3I erdősáv kisemlős közössége}

A közösség első felvételezésekor a négy domináns-szubdomináns faj közel azonos arányát regisztráltam, mely 1994-re a mezei pocok, 1996-ra pedig a közönséges erdeiegér javára tolódott el. Az utolsó évben az 1992-es arány felé való elmozdulást regisztráltam. A 28d ábrából a közösség stabilitása feltünően kirajzolódik.

\section{A Mosonszolnok 4A erdősáv kisemlős közössége}

1992-ben a közösség domináns faja a mezei pocok, mellette a sárganyakú erdeiegér jelenléte emelendő ki. A következő években a mezei pocok szubdomináns vagy ritka helyzetbe szorul vissza, a közönséges erdeiegér válik dominánssá, a sárganyakú erdeiegér pedig mindvégig ritka, vagy hiányzik (28e ábra).

\section{A Mosonszolnok 4C erdősáv kisemlős közössége}

Az első felvételezéskor a mezei pocok dominanciája volt kimutatható a közösségben, mellette még a vöröshátú erdeipocok és a sárganyakú erdeiegér jelenléte volt feltünő. A későbbiekben az addig ritka közönséges erdeiegér és a mezei pocok váltotta egymást a domináns 
pozícióban. A sárganyakú erdeiegér nem ért el jelentős aránynövekedést, a vöröshátú erdeipocok pedig 1999-ben nem is volt kimutatható az erdősávban (28f ábra).

\section{A Jánossomorja 68C erdősáv kisemlős közössége}

1992-ben a közösség domináns faja a mezei pocok, mellette a mezei cickány és a sárganyakú erdeiegér létszámaránya emelendő ki. 1994-re a korábban ritka közönséges erdeiegér válik dominánssá, eltünik a mezei pocok és erősödik a vöröshátú erdeipocok és a sárganyakú erdeiegér állománya. 1997-ben a közönséges erdeiegér dominanciája tovább nő, a két szubdomináns faj visszaszorul, a vöröshátú erdeipocok pedig szubdominánssá válik (28g ábra).

\section{A Jánossomorja 68D erdősáv kisemlős közössége}

1992-ben a sárganyakú erdeiegér a közösség domináns faja, részaránya 1994-re 78\%-ra nő, majd 1997-re ritka helyzetbe szorul vissza. Az első évben jelen lévő fajok közül elöször a vöröshátú erdeipocok, majd a mezei pocok erösödik meg, utóbbi dominánssá is válik (28h ábra).

\section{A Jánossomorja 69B erdősáv kisemlős közössége}

1992-ben a csapdázás a mezei pocok dominanciáját mutatta ki, a másik három gyakori faj összdominanciáját alig meghaladó mértékben. A következő két évben az erdeiegér fajok kerültek domináns helyzetbe, a vöröshátú erdeipocok jelenlétét pedig nem tudtam kimutatni (28i ábra).

\section{A Jánossomorja 69C erdősáv kisemlős közössége}

1992-ben a mezei pocok és a közönséges erdeiegér volt többségben a területen, de mellettük alig volt jelentéktelenebb a másik erdeiegér faj részaránya is. A következő évre az utóbbi vált dominánssá, melyet 1997-ben a mezei pocok váltott fel. Az utolsó évben kimutattam a földi pocok és a vöröshátú erdeipocok jelenlétét is (28j ábra).

\section{A Jánossomorja 69E erdősáv kisemlős közössége}

1992-ben a mezei pocok dominanciája figyelhető meg, a következő évben pedig a közönséges erdeiegér kerül többségbe. A sárganyakú erdeiegér visszaszorul, majd el is tűnik az erdősávból, 1997-re pedig ismét a mezei pocok dominál (28k ábra).

\section{A Jánossomorja 69F erdősáv kisemlős közössége}

Az első vizsgálati évben az erdősáv domináns faja a vöröshátú erdeipocok, jelenlétét azonban a későbbiekben nem sikerült kimutatni. A mellette jelenlévő szubdomináns fajok közül a mezei pocok és a két erdeiegér faj jellemzi az 1994-ben kimutatott közösség szerkezetet. 1997-re a közönséges erdeiegér válik dominánssá (281 ábra). 

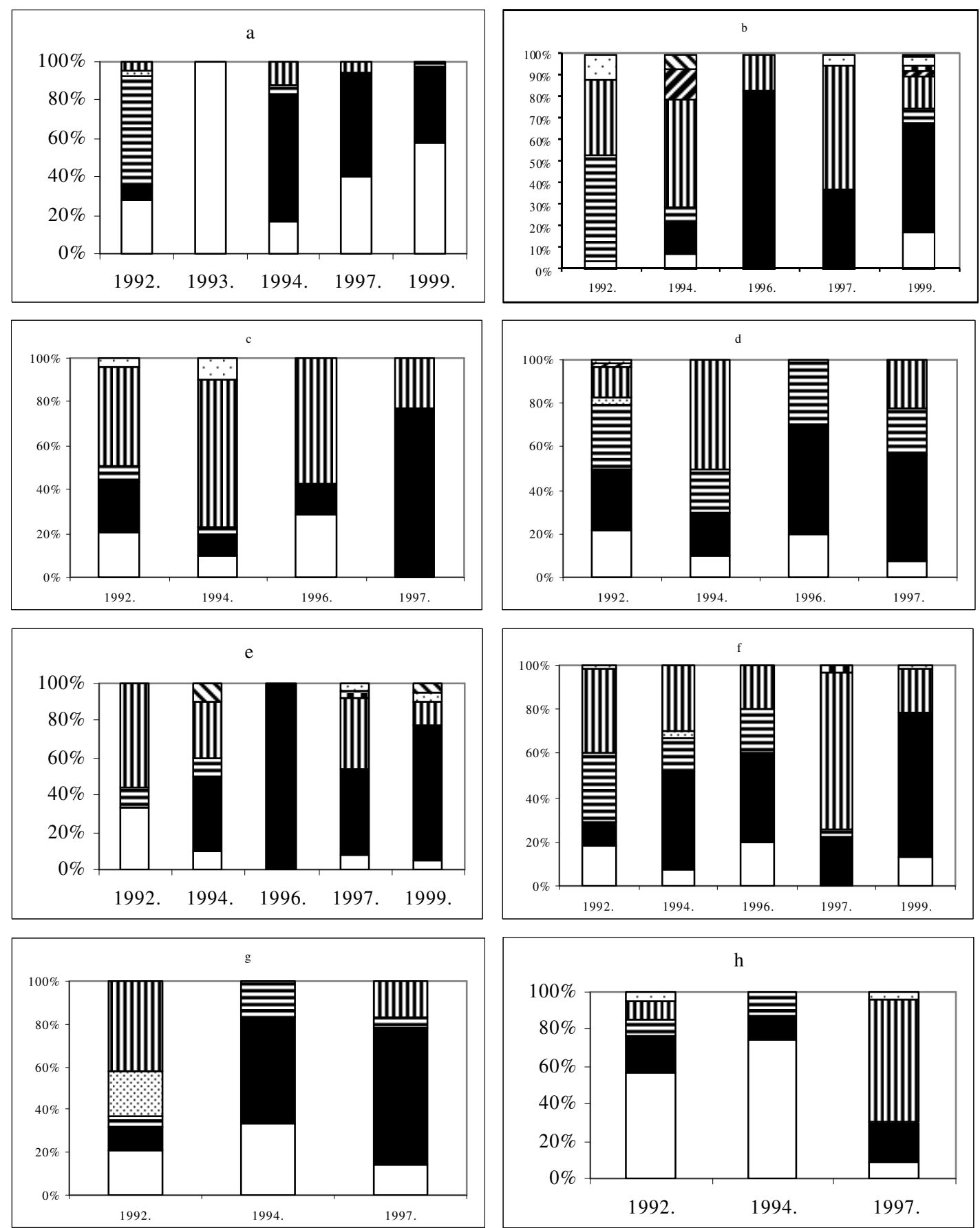

$\square A P O F L A$ APOSYL 目CLEGLA MMCARV $\square$ CROLEU

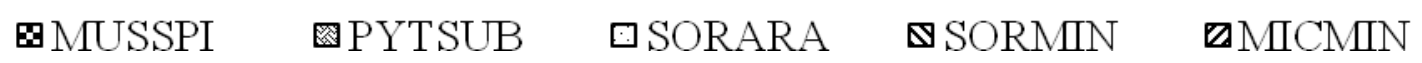

28. ábra: A kisemlős közösségek dinamikája 1992 és 1999 között

Figure 28: Dynamics of the small mammal communities between 1992 and 1999 

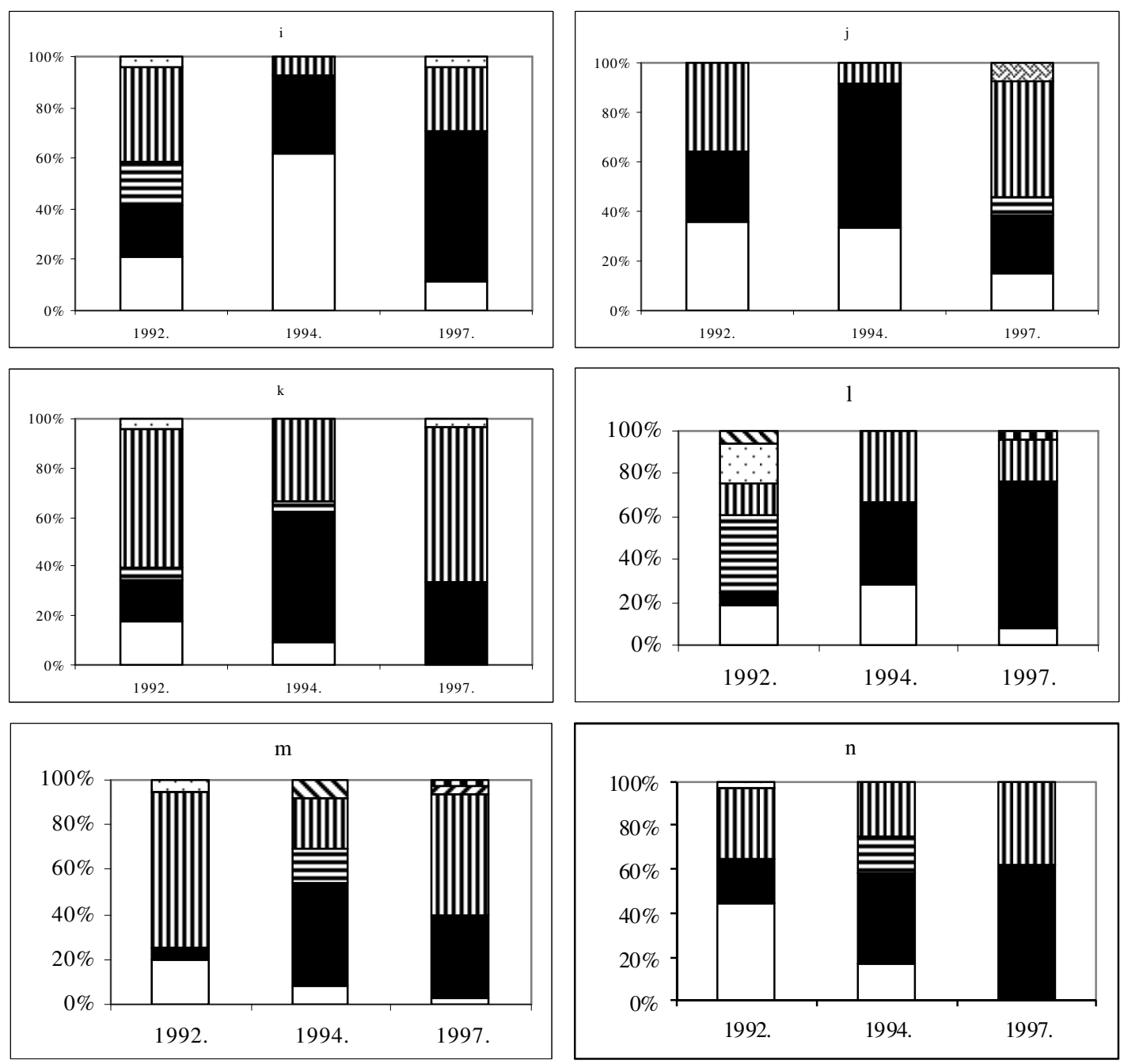

28. ábra (folytatás): A kisemlős közösségek dinamikája 1992. és 1999. között Figure 28 (cont.): Dynamics of the small mammal communities between 1992. and 1999.

\section{A Jánossomorja 70A erdősáv kisemlős közössége}

A mezei pocok első évben tapasztalt domináns helyzetét 1994-re átveszi a közönséges erdeiegér, a következő vizsgált évben azonban az arány ismét megfordul. A másik erdeiegér faj a három év alatt fokozatosan veszt dominanciájából (28m ábra).

\section{A Jánossomorja 70B erdősáv kisemlős közössége}

Az erdősávban a két erdeiegér faj és a mezei pocok versengését tapasztaltam. A vizsgált években először a sárganyakú erdeiegér, majd a közönséges erdeiegér válik dominánssá, előbbi 1997-re el is tünik a területről (28n ábra).

Az egy vegetációs perióduson belüli vizsgálatok eredményeit bemutató ábrákon (29 ábra) a közönséges erdeiegér júliusi dominanciáját figyelhetjük meg mind a négy kvadrátban. A faj domináns jellege három helyen szeptemberig fennmarad, a mezei pocok kismértékü erősödése mellett. A $3 \mathrm{~F}$ jelü akácosban (29 ábra) azonban a sárganyakú erdeiegér fokozatosan visszaszorította az előbbi Apodemus fajt és szeptemberre nagyobb arányú dominanciát mutatott, mint júliusban a közönséges erdeiegér. 

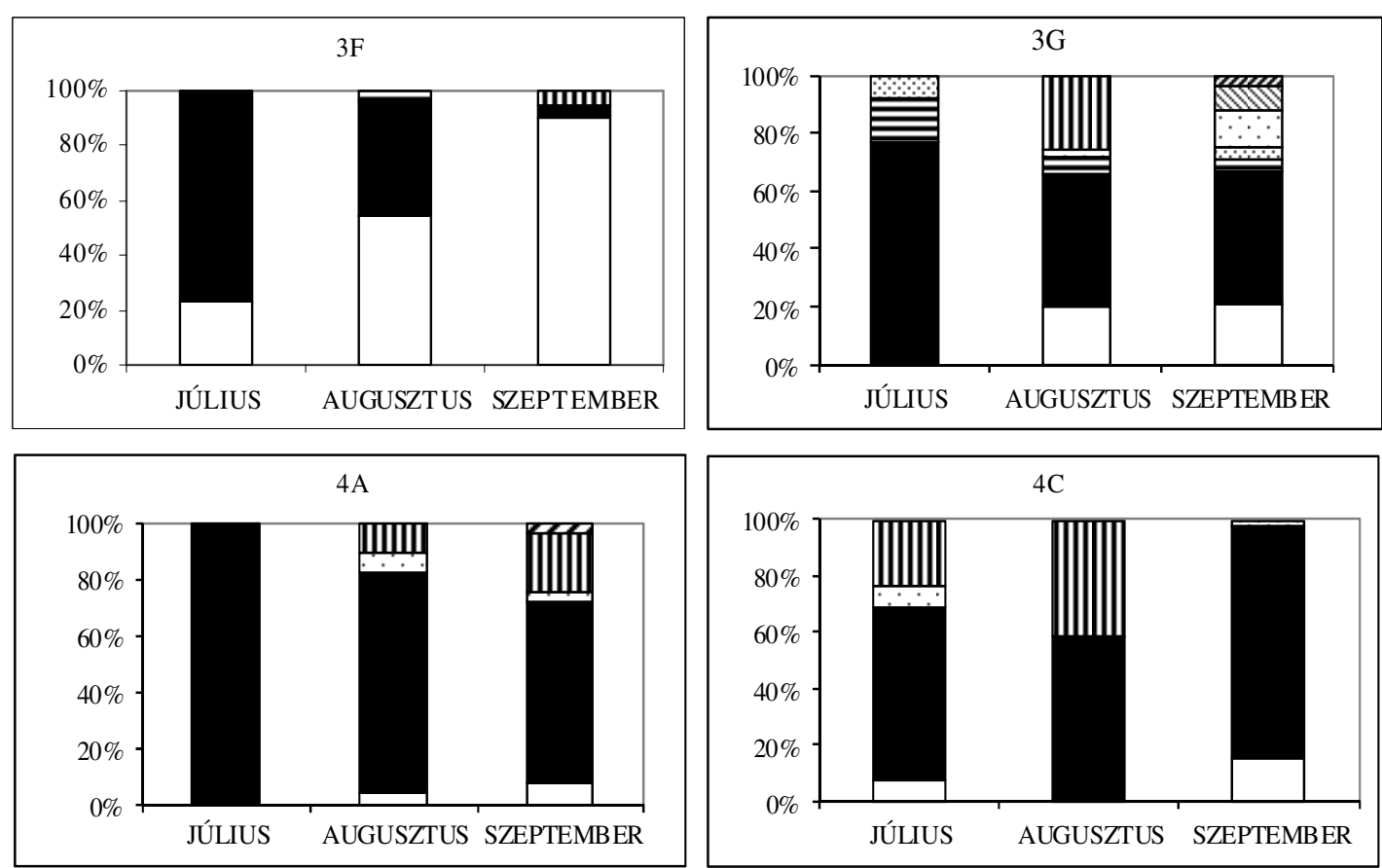

\section{3. ábra: Négy habitat kisemlős közösségének dinamikája 1999-ben (jelmagyarázatot lásd a 28. ábrán)}

Figure 29: Four habitat's dynamics of small mammal communities in 1999. (see tke key on figure 28)

\subsubsection{Diverzitás és egyenletesség}

Áttekintve a négy, népes közösségekkel jellemezhető vizsgálati év diverzitási és egyenletességi értékeit (30. ábra) megállapítható, hogy a „legdiverzebb” kisemlős közösség a 69F jelü erdősávban élt 1992 júliusában (1,6135), a legkisebb diverzitása pedig a 3F területnek volt 1999 szeptemberében (0,4702). Az átlagosan legnagyobb diverzitásokat 1992ben mutatták a közösségek. Az egyenletesség maximuma a 69C erdősávban volt kimutatható 1992-ben (0,9952), minimumát pedig 1999 szeptemberében a 3F területen észleltem $(0,428)$.

A továbbiakban az 5 éven keresztül vizsgált erdősávok kisemlős közösségeinek időbeli diverzitás változását t-próbával hasonlítottam össze (26-29. táblázat) (TóTHMÉRÉSz, 1996). A vizsgálatból kihagytam azokat a csapdázási időszakokat, ahol az alacsony faj- vagy egyedszám értelmezhetetlenné tette volna az összehasonlítást. A t-teszt alapján szignifikáns eltérést mutató közösségek diverzitását RÉNYI-féle diverzitási rendezéssel, valamint ennek elégtelensége esetén faj-abundancia görbék segítségével is összevetettem (31. ábra).

A diverzitási rendezés alapján elmondható, hogy a 3F kvadrátban az 1992-ben regisztrált diverzitás szignifikánsan nagyobb volt az összes később tapasztalt értéknél, kivéve az 1994. évet. Ebben az évben a közösség diverzitása az 1999. szeptemberi és júliusi értéket haladta meg szignifikánsan (31. ábra). 


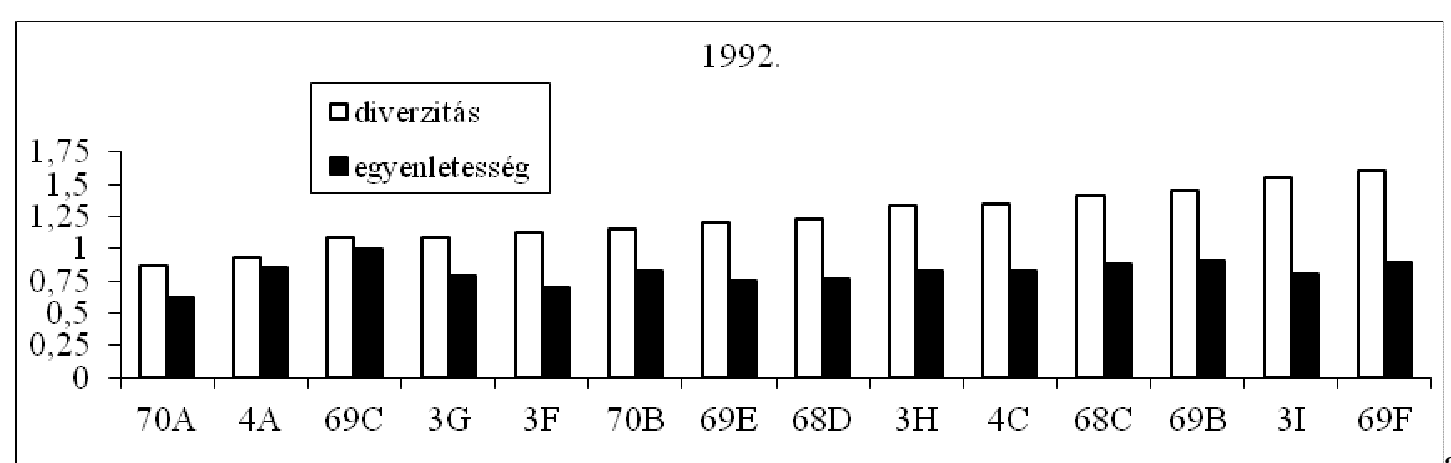

a.
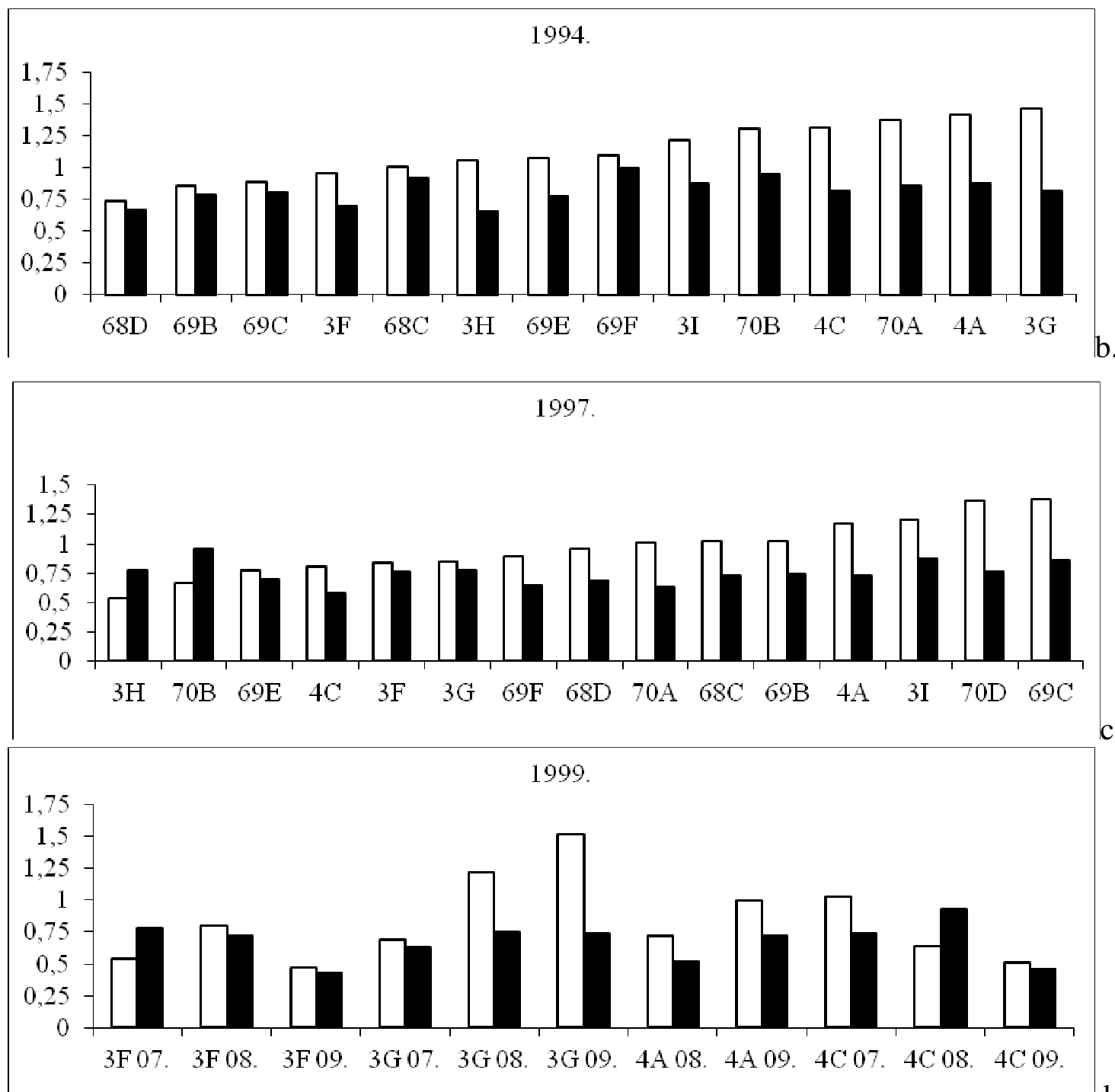

d.

240. ábra: A kisemlős közösségek diverzitás és egyenletesség értékei (jelmagyarázatot lásd a 30/a ábrán)

Figure 30: Diversity and equitability data of the small mammal communities (see the key above)

A 3G kvadrátban az 1992-ben tapasztalt diverzitás az 1996-os és az 1999. szeptemberi értéknél volt szignifikánsan magasabb, az 1994-es érték pedig meghaladta az 1996-ban, 1997-ben és 1999. júliusban kimutatottat. Az 1996-ban csapdázott közösség nem volt olyan 
diverz, mint az 1999. augusztusi és szeptemberi. Az 1997-ben regisztrált diverzitás szignifikánsan meghaladta az 1999. szeptemberi értéket, de kisebb volt az augusztusinál. Az 1999. évben a legkisebb diverzitást júliusban mutatta a közösség, ennél szignifikánsan nagyobb volt az augusztusi és a szeptemberi érték is, utóbbi kettő azonban nem különbözött egymástól statisztikailag igazolható mértékben.

A 4A kvadrátban az 1999. augusztusban regisztrált közösség diverzitása szignifikáns módon kisebb volt mind az 1994-ben, mind az 1997-ben csapdázott közösségeké.

A 4C kvadrátban 1992-ben regisztrált kisemlős közösség diverzitása szignifikánsan meghaladta az 1997-ben, 1999. szeptemberben és augusztusban számolt értéket is. Ugyanez mondható el az 1994-ben és 1996-ban csapdázott közösségek tekintetében is, míg az 1999. júliusi közösség diverzitása a szeptemberinél volt szignifikánsan nagyobb.

26. táblázat: A 3F akácos kisemlős közösségei diverzitásának összehasonlítása (p<0,05, NS= nem szignifikáns)

Table 26: Diversity comparison of the small mammal communities in the $3 \mathrm{~F}$ black locust $(\mathrm{p}<0,05$, NS $=$ not significant)

\begin{tabular}{|c|c|c|c|c|c|}
\hline & $\begin{array}{c}3 F \\
1999.09 .\end{array}$ & $\begin{array}{c}3 F \\
1999.08 .\end{array}$ & $\begin{array}{c}3 F \\
1999.07 .\end{array}$ & $\begin{array}{c}3 F \\
1997 .\end{array}$ & $\begin{array}{c}3 F \\
1994 .\end{array}$ \\
\hline $\begin{array}{l}3 F \\
1992\end{array}$ & $\begin{array}{c}\mathrm{t}=3,1917 \\
\mathrm{df}=39 \\
0,01\end{array}$ & $\begin{array}{c}\mathrm{t}=2,7893 \\
\mathrm{df}=105 \\
0,01\end{array}$ & $\begin{array}{c}\mathrm{t}=3,3885 \\
\mathrm{df}=29 \\
0,001\end{array}$ & $\begin{array}{c}\mathrm{t}=2,3971 \\
\mathrm{df}=110 \\
0,02\end{array}$ & $\begin{array}{c}\mathrm{t}=0,8605 \\
\mathrm{df}=43 \\
\mathrm{NS}\end{array}$ \\
\hline $\begin{array}{l}3 F \\
1994\end{array}$ & $\begin{array}{c}\mathrm{t}=1,9935 \\
\mathrm{df}=47 \\
0,05\end{array}$ & $\begin{array}{c}\mathrm{t}=0,9204 \\
\mathrm{df}=31 \\
\mathrm{NS}\end{array}$ & $\begin{array}{c}\mathrm{t}=1,9178 \\
\mathrm{df}=36 \\
0,05\end{array}$ & $\begin{array}{c}\mathrm{t}=0,6971 \\
\mathrm{df}=32 \\
\mathrm{NS}\end{array}$ & \\
\hline $\begin{array}{l}3 F \\
1997\end{array}$ & $\begin{array}{c}\mathrm{t}=1,8960 \\
\mathrm{df}=30 \\
\mathrm{NS}\end{array}$ & $\begin{array}{c}\mathrm{t}=0,4190 \\
\mathrm{df}=124 \\
\mathrm{NS}\end{array}$ & $\begin{array}{c}\mathrm{t}=1,8822 \\
\mathrm{df}=20 \\
\mathrm{NS}\end{array}$ & & \\
\hline $\begin{array}{l}3 F \\
1999.07\end{array}$ & $\begin{array}{c}\mathrm{t}=0,3066 \\
\mathrm{df}=36 \\
\mathrm{NS}\end{array}$ & $\begin{array}{c}\mathrm{t}=1,6653 \\
\mathrm{df}=18 \\
\mathrm{NS}\end{array}$ & & & \\
\hline $\begin{array}{l}3 F \\
1999.08\end{array}$ & $\begin{array}{c}\mathrm{t}=1,7155 \\
\mathrm{df}=29 \\
\mathrm{NS}\end{array}$ & & & & \\
\hline
\end{tabular}


27. táblázat: A 3G erdősáv kisemlős közösségei diverzitásának összehasonlítása (p<0,05, NS= nem szignifikáns)

Table 27: Diversity comparison of the small mammal communities in the $3 \mathrm{G}$ forest belt $(\mathrm{p}<0,05$, NS=not significant)

\begin{tabular}{|l|l|l|l|l|l|l|}
\hline & 3G-99. 09. & 3G-99. 08. & 3G-99. 07. & 3G-97. & 3G-96. & 3G-94. \\
\hline 3G-92. & $\begin{array}{l}\mathrm{t}=2,1070 \\
\mathrm{df}=47 \\
0,05\end{array}$ & $\begin{array}{l}\mathrm{t}=0,9404 \\
\mathrm{df}=112 \\
\mathrm{NS}\end{array}$ & $\begin{array}{l}\mathrm{t}=1,7370 \\
\mathrm{df}=17 \\
\mathrm{NS}\end{array}$ & $\begin{array}{l}\mathrm{t}=1,7375 \\
\mathrm{df}=43 \\
\mathrm{NS}\end{array}$ & $\begin{array}{l}\mathrm{t}=2,4848 \\
\mathrm{df}=8 \\
0,02\end{array}$ & $\begin{array}{l}\mathrm{t}=1,5934 \\
\mathrm{df}=19 \\
\mathrm{NS}\end{array}$ \\
\hline 3G-94. & $\begin{array}{l}\mathrm{t}=0,1817 \\
\mathrm{df}=33 \\
\mathrm{NS}\end{array}$ & $\begin{array}{l}\mathrm{t}=1,0835 \\
\mathrm{df}=19 \\
\mathrm{NS}\end{array}$ & $\begin{array}{l}\mathrm{t}=2,4305 \\
\mathrm{df}=27 \\
0,02\end{array}$ & $\begin{array}{l}\mathrm{t}=2,5339 \\
\mathrm{df}=22 \\
0,02\end{array}$ & $\begin{array}{l}\mathrm{t}=3,1097 \\
\mathrm{df}=15 \\
0,01\end{array}$ & \\
\hline 3G-96. & $\begin{array}{l}\mathrm{t}=3,5067 \\
\mathrm{df}=14 \\
0,001\end{array}$ & $\begin{array}{l}\mathrm{t}=2,9230 \\
\mathrm{df}=8\end{array}$ & $\begin{array}{l}\mathrm{t}=0,7993 \\
\mathrm{df}=15\end{array}$ & $\begin{array}{l}\mathrm{t}=1,4572 \\
\mathrm{df}=9 \\
\mathrm{NS}\end{array}$ & & \\
\hline 3G-97. & $\begin{array}{l}\mathrm{N}=3,1342 \\
\mathrm{df}=50 \\
0,01\end{array}$ & $\begin{array}{l}\mathrm{t}=2,5120 \\
\mathrm{df}=46 \\
0,02\end{array}$ & $\begin{array}{l}\mathrm{t}=0,6372 \\
\mathrm{df}=20 \\
\mathrm{NS}\end{array}$ & & & \\
\hline 3G-99. 07. & $\begin{array}{l}\mathrm{t}=2,9228 \\
\mathrm{df}=31 \\
0,01\end{array}$ & $\begin{array}{l}\mathrm{t}=2,2181 \\
\mathrm{df}=18\end{array}$ & & & & \\
0,05 & & & & \\
\hline 3G-99. 08. & $\begin{array}{l}\mathrm{t}=1,5099 \\
\mathrm{df}=48 \\
\mathrm{NS}\end{array}$ & & & & & \\
\hline
\end{tabular}

28. táblázat: A 4A erdősáv kisemlős közösségei diverzitásának összehasonlítása (p<0,05, NS= nem szignifikáns)

Table 28: Diversity comparison of the small mammal communities in the $4 \mathrm{~A}$ forest belt $(\mathrm{p}<0,05, \quad \mathrm{NS}=$ not significant)

\begin{tabular}{|l|l|l|l|l|}
\hline & 4A-99. 09. & 4A-99. 08. & 4A-97. & 4A-94. \\
\hline \multirow{3}{*}{ 4A-92. } & $\mathrm{t}=0,3002$ & $\mathrm{t}=0,9397$ & $\mathrm{t}=1,0502$ & $\mathrm{t}=1,9184$ \\
& $\mathrm{df}=24$ & $\mathrm{df}=28$ & $\mathrm{df}=24$ & $\mathrm{df=19}$ \\
& $\mathrm{NS}$ & $\mathrm{NS}$ & $\mathrm{NS}$ & $\mathrm{NS}$ \\
\hline \multirow{3}{*}{ 4A-94. } & $\mathrm{t}=1,7549$ & $\mathrm{t}=2,8139$ & $\mathrm{t}=1,0307$ & \\
& $\mathrm{df}=23$ & $\mathrm{df}=27$ & $\mathrm{df}=23$ & \\
& $\mathrm{NS}$ & 0,01 & $\mathrm{NS}$ & \\
\hline \multirow{3}{*}{ 4A-97. } & $\mathrm{t}=0,8129$ & $\mathrm{t}=2,0507$ & & \\
& $\mathrm{df}=56$ & $\mathrm{df}=60$ & & \\
& $\mathrm{NS}$ & 0,05 & & \\
\hline \multirow{3}{*}{ 4A-99. 08. 08. } & $\mathrm{t}=1,3079$ & & & \\
& $\mathrm{df}=64$ & & & \\
& $\mathrm{NS}$ & & & \\
\hline
\end{tabular}


29. táblázat: A 4C erdősáv kisemlős közösségei diverzitásának összehasonlítása (p<0,05, NS= nem szignifikáns)

Table 29: Diversity comparison of the small mammal communities in the $4 \mathrm{C}$ forest belt $(\mathrm{p}<0,05$, NS $=$ not significant)

\begin{tabular}{|c|c|c|c|c|c|c|}
\hline & 4C-99. 09. & 4C-99. 08. & 4C-99. 07. & 4C-97. & $4 \mathrm{C}-96$. & $4 \mathrm{C}-94$. \\
\hline $4 \mathrm{C}-92$. & $\begin{array}{l}t=6,4014 \\
d f=83 \\
0,001\end{array}$ & $\begin{array}{l}\mathrm{t}=8,4666 \\
\mathrm{df}=105 \\
0,001\end{array}$ & $\begin{array}{l}\mathrm{t}=1,4087 \\
\mathrm{df}=16 \\
\mathrm{NS}\end{array}$ & $\begin{array}{l}\mathrm{t}=3,3051 \\
\mathrm{df}=44 \\
0,001\end{array}$ & $\begin{array}{l}\mathrm{t}=0,0848 \\
\mathrm{df}=7 \\
\mathrm{NS}\end{array}$ & $\begin{array}{l}\mathrm{t}=0,1924 \\
\mathrm{df}=43 \\
\mathrm{NS}\end{array}$ \\
\hline $4 C-94$. & $\begin{array}{l}\mathrm{t}=4,7837 \\
\mathrm{df}=64 \\
0,001\end{array}$ & $\begin{array}{l}\mathrm{t}=4,9708 \\
\mathrm{df}=35 \\
0,001\end{array}$ & $\begin{array}{l}\mathrm{t}=1,1569 \\
\mathrm{df}=23 \\
\mathrm{NS}\end{array}$ & $\begin{array}{l}\mathrm{t}=2,6269 \\
\mathrm{df}=57 \\
0,02\end{array}$ & $\begin{array}{l}\mathrm{t}=0,0686 \\
\mathrm{df}=13 \\
\mathrm{NS}\end{array}$ & \\
\hline $4 C-96$. & $\begin{array}{l}\mathrm{t}=4,3687 \\
\mathrm{df}=12 \\
0,001\end{array}$ & $\begin{array}{l}\mathrm{t}=4,3282 \\
\mathrm{df}=6 \\
0,001\end{array}$ & $\begin{array}{l}\mathrm{t}=1,1490 \\
\mathrm{df}=18 \\
\mathrm{NS}\end{array}$ & $\begin{array}{l}\mathrm{t}=2,4841 \\
\mathrm{df}=17 \\
0,02\end{array}$ & & \\
\hline 4C-97. & $\begin{array}{l}t=1,5663 \\
d f=63 \\
N S\end{array}$ & $\begin{array}{l}\mathrm{t}=1,0045 \\
\mathrm{df}=37 \\
\mathrm{NS}\end{array}$ & $\begin{array}{l}\mathrm{t}=0,8853 \\
\mathrm{df}=26 \\
\mathrm{NS}\end{array}$ & & & \\
\hline $4 \mathrm{C}-99.07$. & $\begin{array}{l}t=2,1817 \\
d f=21 \\
0,05\end{array}$ & $\begin{array}{l}\mathrm{t}=1,7853 \\
\mathrm{df}=14 \\
\mathrm{NS}\end{array}$ & & & & \\
\hline 4C-99. 08. & $\begin{array}{l}t=1,1052 \\
d f=66 \\
\text { NS }\end{array}$ & & & & & \\
\hline
\end{tabular}

\section{3. A kisemlős közösségek és az élőhelyszerkezet közti összefüggések}

Az egyes kisemlős fajok elterjedési és állományviszonyai között részletezett mikrohabitat vizsgálatok kimutatták, hogy a kisemlősök bizonyos mikrohabitatokat előnyben részesítenek, míg másokat kevésbé használnak. A habitatok növényzete a kisemlösök számára táplálékul és búvóhelyül egyaránt szolgál. Ebből kiindulva feltételezhetnénk, hogy a habitatokra vegetációjuk szerkezetének, ill. karakterisztikáinak megfelelö összetételü kisemlös közösségek jellemzőek. Ugyanakkor a fenti elemzések során kirajzolódott, hogy a közösségek szerkezete a vegetációs periódusok között és azokon belül is jelentősen változik, a dominancia viszonyok évröl évre, de akár 2-3 hónap alatt is átrendeződhetnek.

A több éven át végzett vizsgálat lehetőséget biztosított arra, hogy az erdősávokat egyrészt, mint kisemlős habitatokat, másrészt pedig, mint vegetációs egységeket hasonlítsam össze. A clusteranalízis segítségével nyert dendrogrammok vizsgálati periódusonként megfeleltethetők voltak egymásnak (31. ábra).

A közösségek hasonlóságát szemléltető dendrogrammok alapján vizsgálati évenként az alábbiakat állapítottam meg:

\section{2.}

16 erdősávban történt csapdázás, melyek kisemlős közösségeik alapján három nagy hasonlósági csoportot alkotnak (31/a ábra):

csoport: 69F, 70B, 70D, 68D erdősávok

csoport: 70A, 70C, 69E, 69B, 68C, 69C, 4A erdősávok

csoport: $3 \mathrm{H}, 4 \mathrm{C}, 3 \mathrm{G}, 3 \mathrm{I}, 3 \mathrm{~F}$ erdősávok

Ugyanezen 16 erdősáv vegetációja öt csoportra oszlott a clusteranalízis alapján (31/b ábra):

csoport: 70A, 69E erdősávok

csoport: 69F, 68C erdősávok

csoport: 68D, 4A, 70D, 70B, 3I erdősávok

csoport: 70C, 69B, 3H erdősávok

csoport: 4C, 3G, 69C, 3F erdősávok 

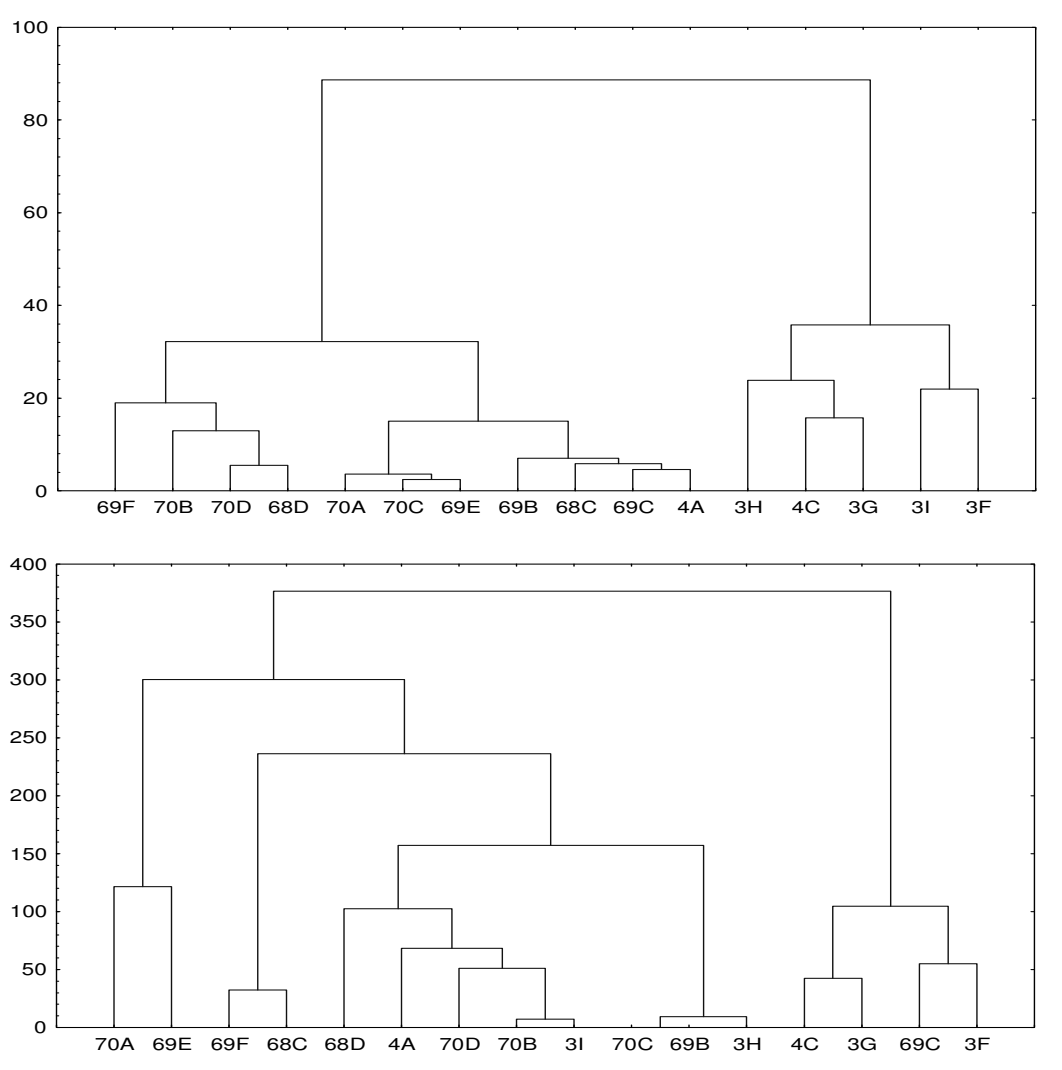

$\mathbf{a}$
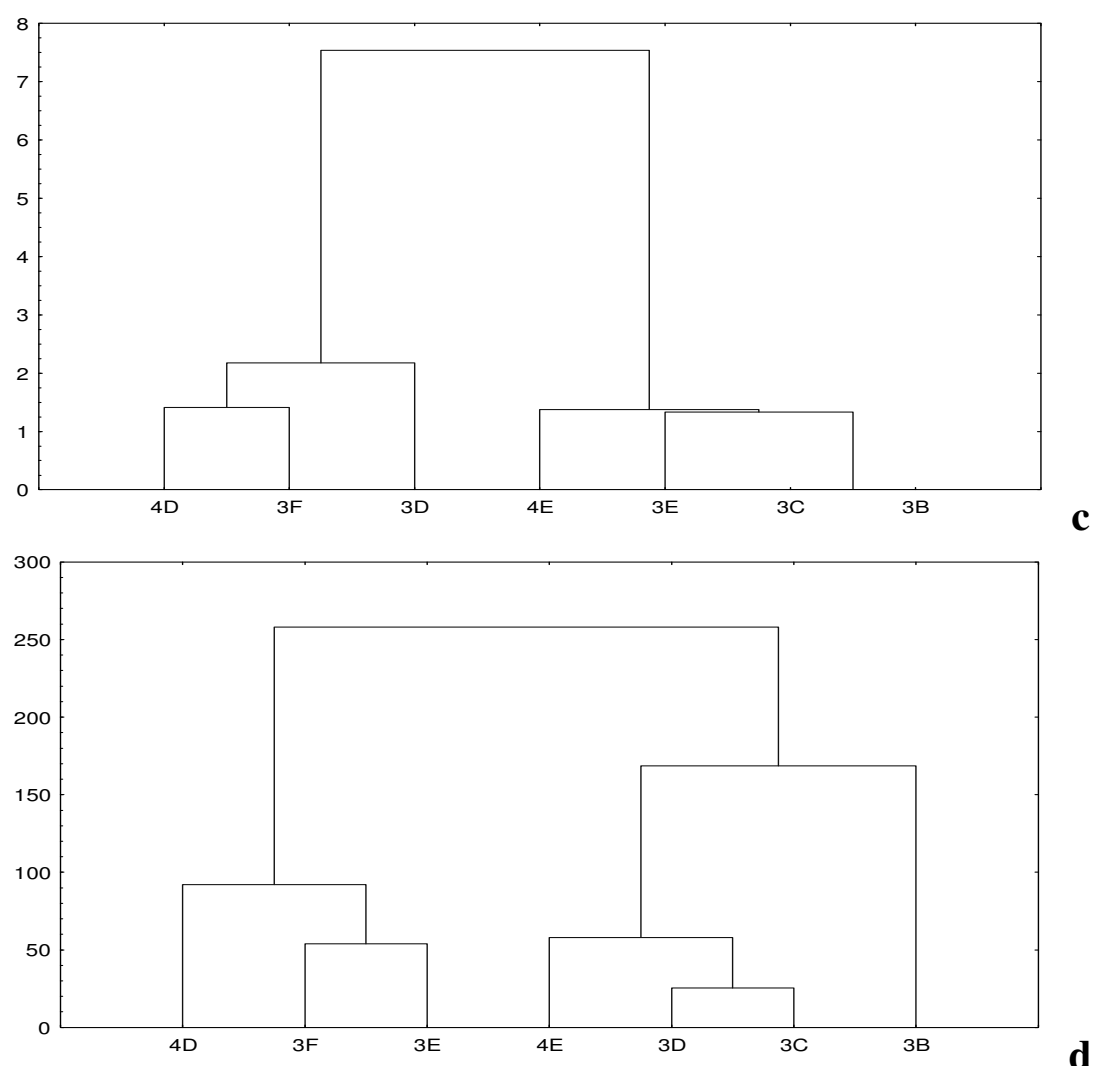

d

31. ábra: A kisemlős közösségek és a fásszárú vegetáció clusteranalízissel történt elemzésének eredményei

Figure 31: Results of cluster analyze of the small mammal communities and dendroflora 

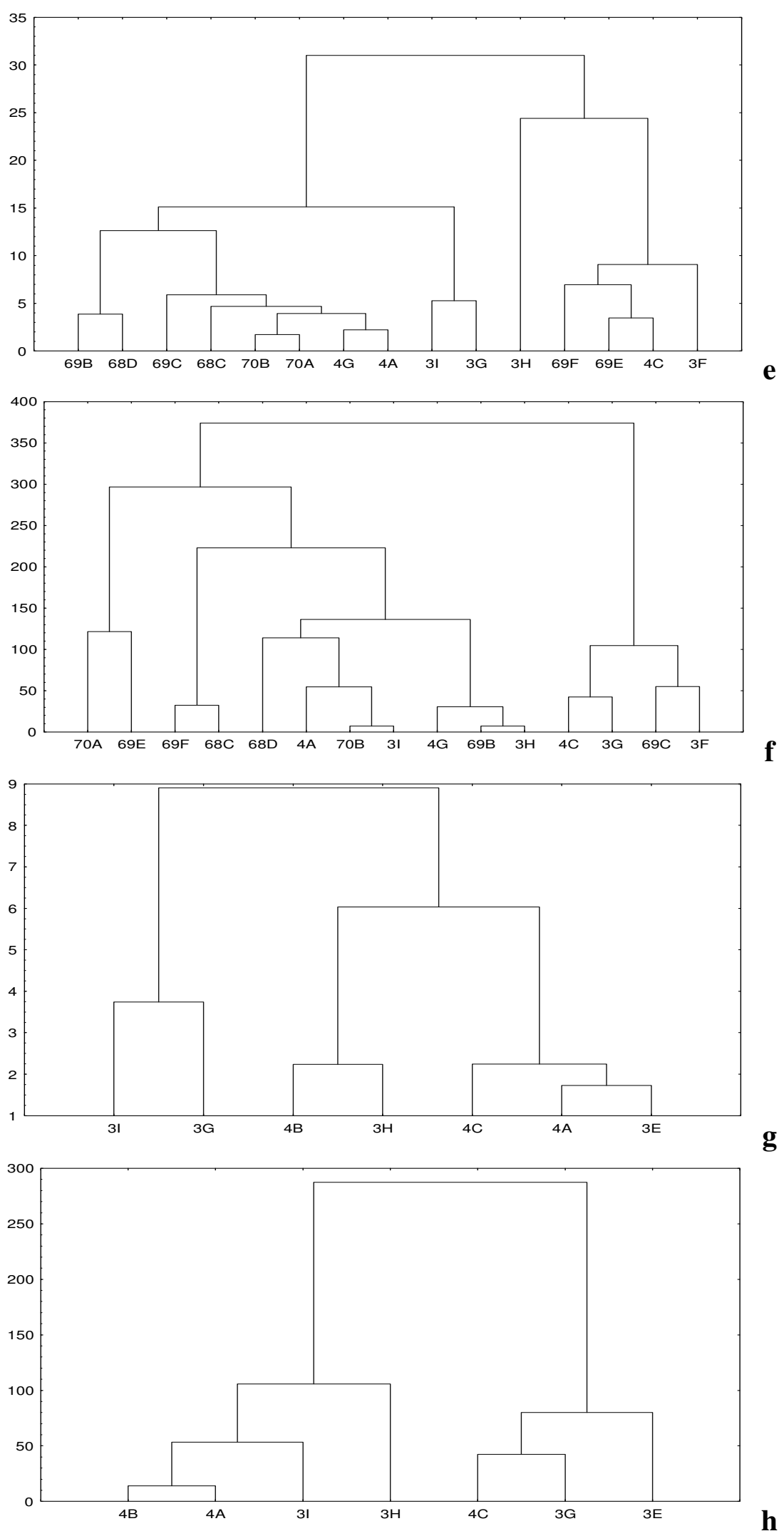

31. ábra (folytatás): A kisemlős közösségek és a fásszárú vegetáció clusteranalízissel történt elemzésének eredményei

Figure 31 (cont.): Results of cluster analyze of the small mammal communities and dendroflora 

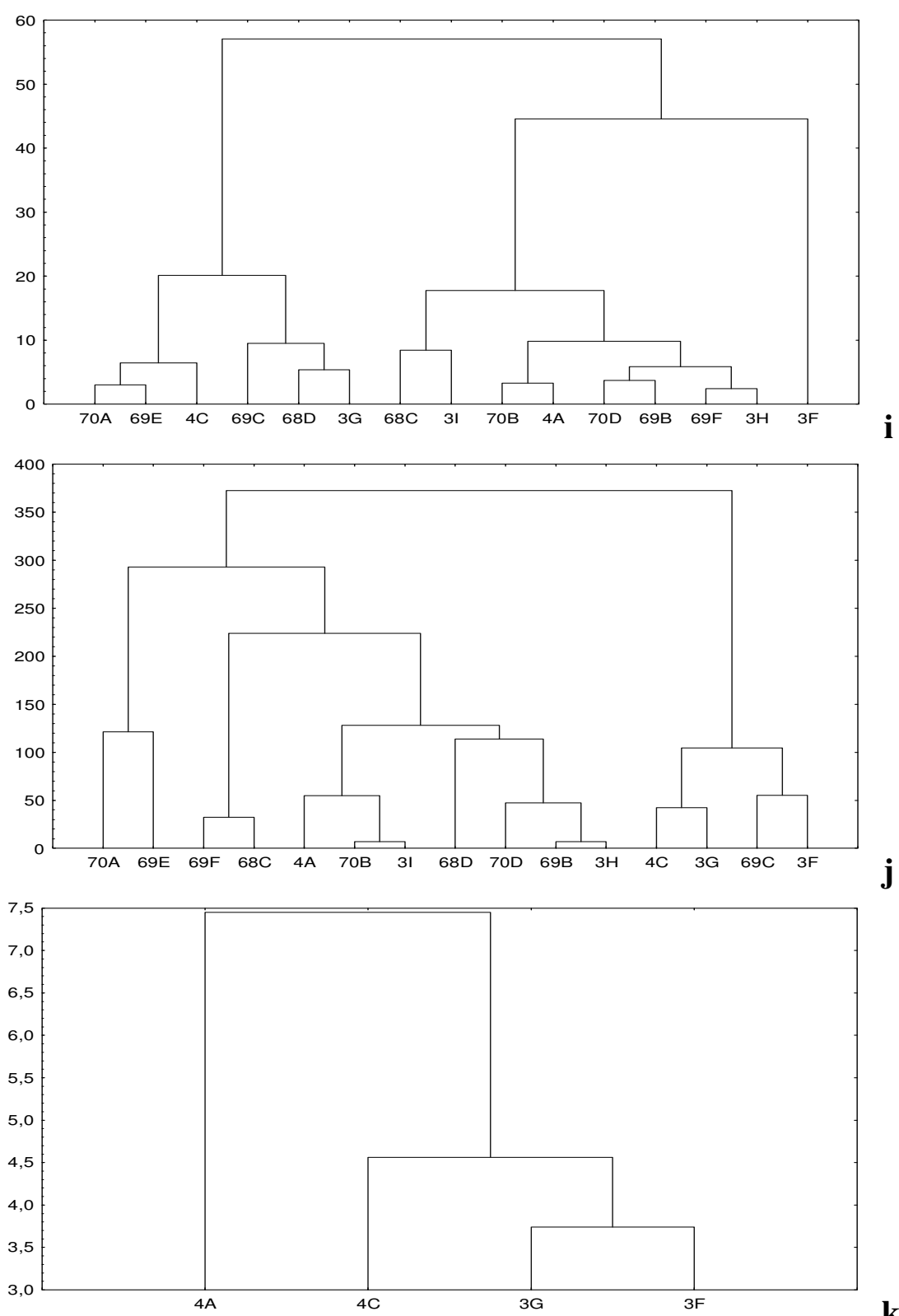

$\mathbf{k}$

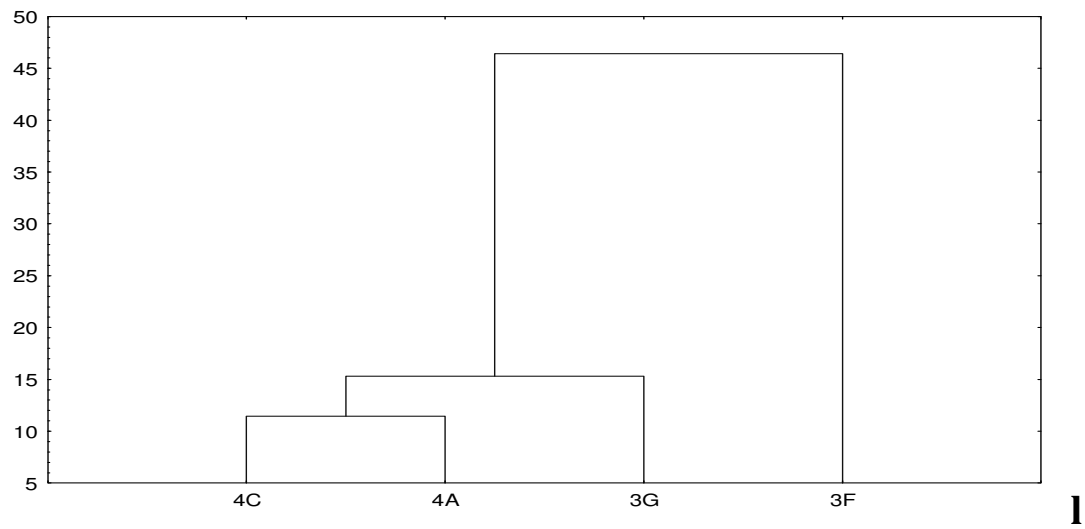

31. ábra (folytatás): A kisemlős közösségek és a fásszárú vegetáció clusteranalízissel történt elemzésének eredményei

Figure 31 (cont.): Results of cluster analyze of the small mammal communities and dendroflora 

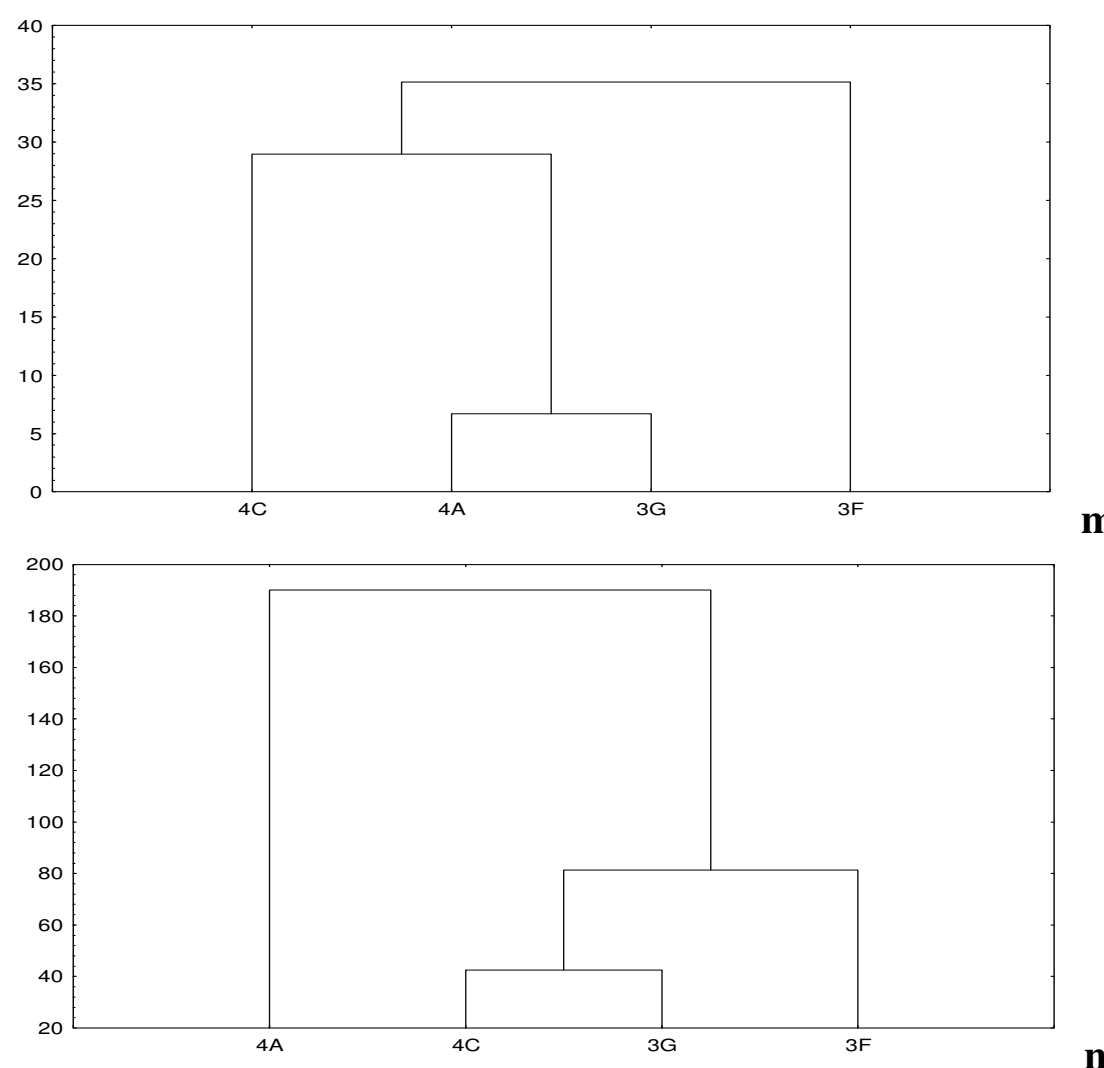

31. ábra (folytatás): A kisemlős közösségek és a fásszárú vegetáció clusteranalízissel történt elemzésének eredményei (fúziós stratégia: Eltérésnégyzetösszeg-növekedés minimalizálása (WARD 1963, ORLóCZI 1967, WishaRT 1969 IDÉZI PODANI 1997) hasonlósági formula: Euklidészi távolság) Figure 31 (cont.): Results of cluster analyze of the small mammal communities and dendroflora

A két dendrogramm hasonlósági csoportjaiban együtt szerepelnek a $3 \mathrm{G}-3 \mathrm{~F}-4 \mathrm{C}$ (3. és 5 . csoport), továbbá a 69B-70C erdősávok (2. és 4. csoport), ezek az élőhelyek tehát kisemlős közösségük és vegetációjuk alapján is hasonlóak egymáshoz.

\section{3}

7 erdősávban csapdáztam, melyek kisemlős közösségeik alapján két hasonlósági csoportot alkotnak (31/c ábra):

csoport: 4D, 3F, 3D erdősávok

csoport: 4E, 3E, 3C, 3B erdősávok

Ugyanez a 7 erdősáv vegetációja szintén két csoportra oszlott a clusteranalízis alapján (31/d ábra):

csoport: 4D, 3F, 3E erdősávok
csoport: 4E, 3D, 3C erdősávok

A 3B erdősáv nem került bele egyik hasonlósági csoportba sem.

A két dendrogramm hasonlósági csoportjaiban együtt szerepelnek a 4D-3F (mindkét esetben 1. csoport), továbbá a 4E-3C erdősávok (2. sz. csoportokban), ezek az élőhelyek tehát kisemlős közösségük és vegetációjuk alapján is hasonlóak egymáshoz. 


\section{4}

15 erdősávban történt csapdázás, melyek kisemlős közösségeik alapján négy nagy hasonlósági csoportot alkotnak (31/e ábra):

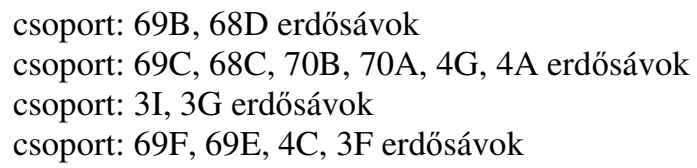

A 3H erdősáv nem került bele egyik hasonlósági csoportba sem.

A 15 erdősáv vegetációja öt csoportra oszlott a clusteranalízis alapján (31/f ábra):

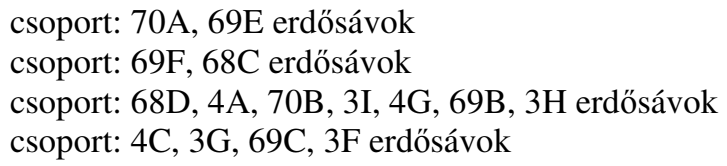

A két dendrogramm hasonlósági csoportjaiban együtt szerepelnek a 70B-4A-4G (2. és 3 . csoport), továbbá a 3F-4C erdősávok (4. sz. csoportok), ezek az élőhelyek tehát kisemlős közösségük és vegetációjuk alapján egyaránt hasonlóak egymáshoz.

\section{6}

7 erdősávban csapdáztam, ezek kisemlös közösségeik alapján három hasonlósági csoportot alkotnak (31/g ábra):

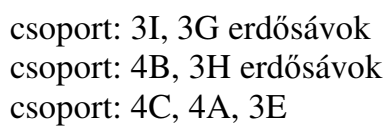

A 7 erdősáv vegetációja két csoportra oszlott (31/h ábra):

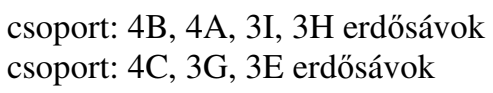

A két dendrogramm hasonlósági csoportjaiban együtt szerepelnek a 4B-3H (2., ill. 1. csoport), továbbá a 3E-4C erdősávok (3. és 2. csoportokban). Ezek az élöhelyek kisemlős közösségük és vegetációjuk alapján egyaránt hasonlóak egymáshoz.

1997

15 erdősávban csapdáztam, melyek kisemlős közösségeik alapján négy hasonlósági csoportot alkotnak (31/i ábra):

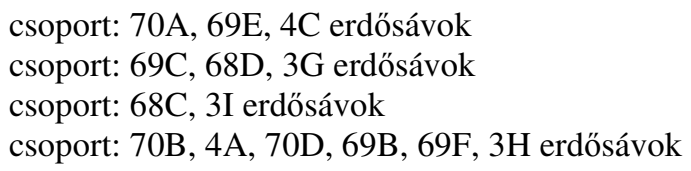

A 3F akácos nem került bele egyik hasonlósági csoportba sem.

Ugyanez a 15 erdősáv vegetációja szintén négy csoportra oszlott a clusteranalízis alapján (31/j ábra): 
csoport: 70A, 69E erdősávok csoport: 69F, 68C erdősávok csoport: 68D, 4A, 70D, 69B, 3H, 70B, 3I erdősávok

csoport: 4C, 3G, 69C, 3F erdősávok

A két dendrogramm hasonlósági csoportjaiban együtt szerepelnek a 70A-69E (mindkét esetben 1. csoport), továbbá a 70B-4A-69B-3H erdősávok (4. és 3. sz. csoportokban), ezek az élöhelyek tehát kisemlös közösségük és vegetációjuk alapján is hasonlóak.

\section{9 - 1. csapdázási időszak: július}

Négy kvadrátban csapdáztam, ezek közül a 4C, 3G, 3F kvadrátok kisemlös közösségeik alapján egy hasonlósági csoportot alkotnak, a 4A kvadrátot a csoporton kívülre helyezte a clusteranalízis (32/k ábra).

\section{9 - 2. csapdázási időszak: augusztus}

A négy kvadrát közül a 4A, a 3G és a 4C került egy csoportba, a 3F különbözött tőlük (32/l ábra).

\section{9 - 3. csapdázási időszak: szeptember}

A hasonlóság itt is a 4A, 3G, 4C kvadrátok közt volt a legnagyobb, leginkább pedig a 3F különbözött a többitöl (31/m ábra).

A négy kvadrát vegetációjának elemzéséből a 4A kvadrát különállása tünik ki, a másik három pedig egy hasonlósági csoportba került (31/n ábra).

A négy, 1999-es évben készült dendrogrammban a 4C és 3G kvadrátok minden esetben egy hasonlósági csoportba kerültek, ami megerősíti, hogy ezek az élőhelyek kisemlős közösségük és vegetációjuk alapján is hasonlóak.

Áttekintve a teljes vizsgálati időszakban azokat az élőhelyeket, amelyek egyaránt hasonlónak mutatkoztak kisemlős közösségük és vegetációjuk alapján is, található köztük több évben egyaránt előforduló párosítás is:

A 4C-3G erdősávok 1992-ben és 1999. mindhárom csapdázási periódusában egy csoportban volt, a 3F-4C páros1992-ben és 94-ben, a 70B-4A pedig 1994-ben és 97-ben is egy csoportba került. Mindez azt jelenti, hogy ezekben az élőhelypárokban, különböző élőhelyekkel való összehasonlítások alkalmával, több éven keresztül, hasonló kisemlős közösséget és egyben hasonló vegetáció szerkezetet sikerült kimutatni.

Az 1999-ben vizsgált kvadrátok kisemlös közössége és gyepszintjének összetétele tekintetében a mozaikosság mérésére alkalmas WHITTAKER-féle $\beta$-diverzitás $\left(\beta_{\mathrm{W}}\right)$ értékét is kiszámoltam (TÓTHMÉRÉSZ, 1998). Ennek nagysága azt fejezi ki, hogy a vizsgált kvadráton belül miként oszlik meg a fajkészlet a kvadrát csapdasorai között. Ha minden csapdasorban előfordul a kvadrát minden faja, a $\beta_{\mathrm{W}}=0$, minél kevesebb faj van jelen a teljes fajkészletböl, annál nagyobb a $\beta_{\mathrm{W}}$. A két értéket egymás mellett megjelenítő 33. ábra szemlélteti, hogy a nagyobb növényzet-beli mozaikosságot mutató kvadrátokban a kisemlős közösség $\beta_{\mathrm{W}}-$ diverzitása is nagyobb. A változás trendje az élőhely és a kisemlősök tekintetében egyaránt lineáris regresszióval írható le $\left(\mathrm{r}^{2}=0,667\right.$, ill. $\left.\mathrm{r}^{2}=0,8727\right)$. A legkisebb mozaikosság értéket a $3 \mathrm{~F}$ jelü akácos, a legnagyobbat pedig a $4 \mathrm{C}$ erdősávra helyezett kvadrát mutatja. 


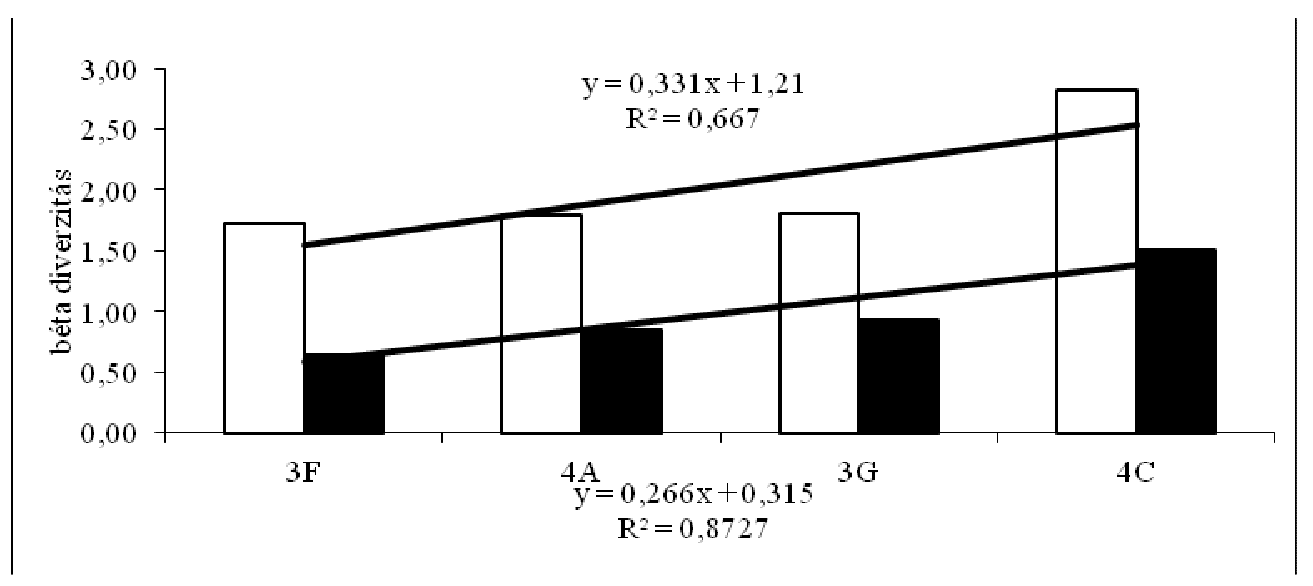

\section{2. ábra: A WHITTAKER-féle $\beta$-diverzitás értékei (gyepszint fehérrel, kisemlős közösség feketével)}

Figure 32: Data of WHITTAKER $\beta$-diversity (herb layer with white and small mammal community with black)

\subsection{Az erdősáv-rendszer zöld folyosó szerepének vizsgálata a kisemlős metapopulációk fenntartásában}

Mivel táji léptékben tekintve, az általam kutatott terület egy teljesen átalakított kultúrtáj, ahol az eredeti vegetáció helyén intenzíven kezelt mezőgazdasági területeket találunk, célszerü megvizsgálni, hogy a fragmentáció eredményeként kialakult helyzetben a kisemlösök a humán tér mely részét, miként képesek benépesíteni.

A mikrohabitat vizsgálatoknál sikerült kimutatni, hogy a kisemlős fajok eltérően használják a különböző növényzeti jellemzőkkel bíró élőhelyeket. Az erdeiegér fajok a 23 csapdázott erdősáv több mint 90 \%-ában kimutathatóak voltak. A közönséges erdeiegér különböző preferenciával, de az összes vizsgált mikrohabitatot használta (10. ábra). A sárganyakú erdeiegér csak a mikrohabitatok 7 \%-ában fordult elö, egyáltalán nem használta a lucerna, a kukorica és a tárcsázott borsótarló területét (16. ábra). A vöröshátú erdeipocok az erdősávok 74\%-ában volt kimutatható, míg a mezei pocok az erdősávok 83, a mikrohabitatok 52 \%-ából került elő.

A tárgyalt négy gyakori kisemlös fajból három (erdeiegér fajok és a vöröshátú erdeipocok) az európai mérsékelt övi erdők tipikus generalistája (HORVÁTH \& LANSZKI, 2000). Az említett fajok metapopulációinak fennmaradása szempontjából két kérdéskör vizsgálatát tartottam alapvető fontosságúnak. Egyrészt lényeges áttekinteni, hogy az erdősávoktól a mezőgazdasági kultúrák belseje fele haladva, hogyan változik a kisemlős közösségek fajkészlete, denzitása és diverzitása. Ezzel a vizsgálattal kimutatható, hogy az erdősáv a mezőgazdasági kultúrák által uralt térben azokhoz hasonló, vagy markánsan eltérő kisemlős közösségek élőhelye-e, koncentrál-e bizonyos fajokat. Másrészt pedig vizsgálni szükséges, hogy az erdősávok rendszere valóban zöld folyosóként müködik-e ebben a térben, azaz van-e fajkicserélődés a csatlakozó sávok között.

Az első kérdéskört célzó vizsgálatban az 1999. évben kutatott 4 kvadrátból a kizárólag akácerdőben lévő $3 \mathrm{~F}$ jelüt alkalmaztam kontrollként, míg a másik három, erdősávon túl, a mezőgazdasági táblákba is benyúló kvadrát fogási adatait összevontam.

Az utóbbi három kvadrátban összehasonlítva az erdősávok középvonalától kifele haladva 10 méterenként elhelyezkedő csapdasorok fogási adatainak fajonkénti megoszlását, a 34/a ábrát kaptam eredményül. Az ábrát elemezve jól látható, hogy a jellemzően erdei élőhelyekhez kötődő kisemlős fajok, az Apodemus flavicollis, a Sorex araneus és a Clethrionomys glareolus kizárólag az erdősávban fordultak elő $(0 \mathrm{~m}, 10 \mathrm{~m}, 20 \mathrm{~m}$ 
csapdasorok). A mezei élöhelyeken elsősorban domináló Microtus arvalis és Apodemus sylvaticus dominanciája az erdősávban mutatta a legkisebb értékeket (33/a ábra). A mezőgazdasági területen lévő csapdasorok $(40 \mathrm{~m}, 50 \mathrm{~m})$ viszont kizárólag e két faj egyedeit fogták.

A 3F akácerdőben, az erdő belsejétől $(60 \mathrm{~m})$ az erdőszélig $(0 \mathrm{~m})$ elvégzett, hasonló összehasonlítás fogási adatai szintén jelzik a mezőgazdasági kultúrához legközelebb eső erdőszélben a mezei pocok megjelenését. Az erdő belsejében a két Apodemus faj és a vöröshátú erdeipocok alkotja a közösséget (33/b ábra).

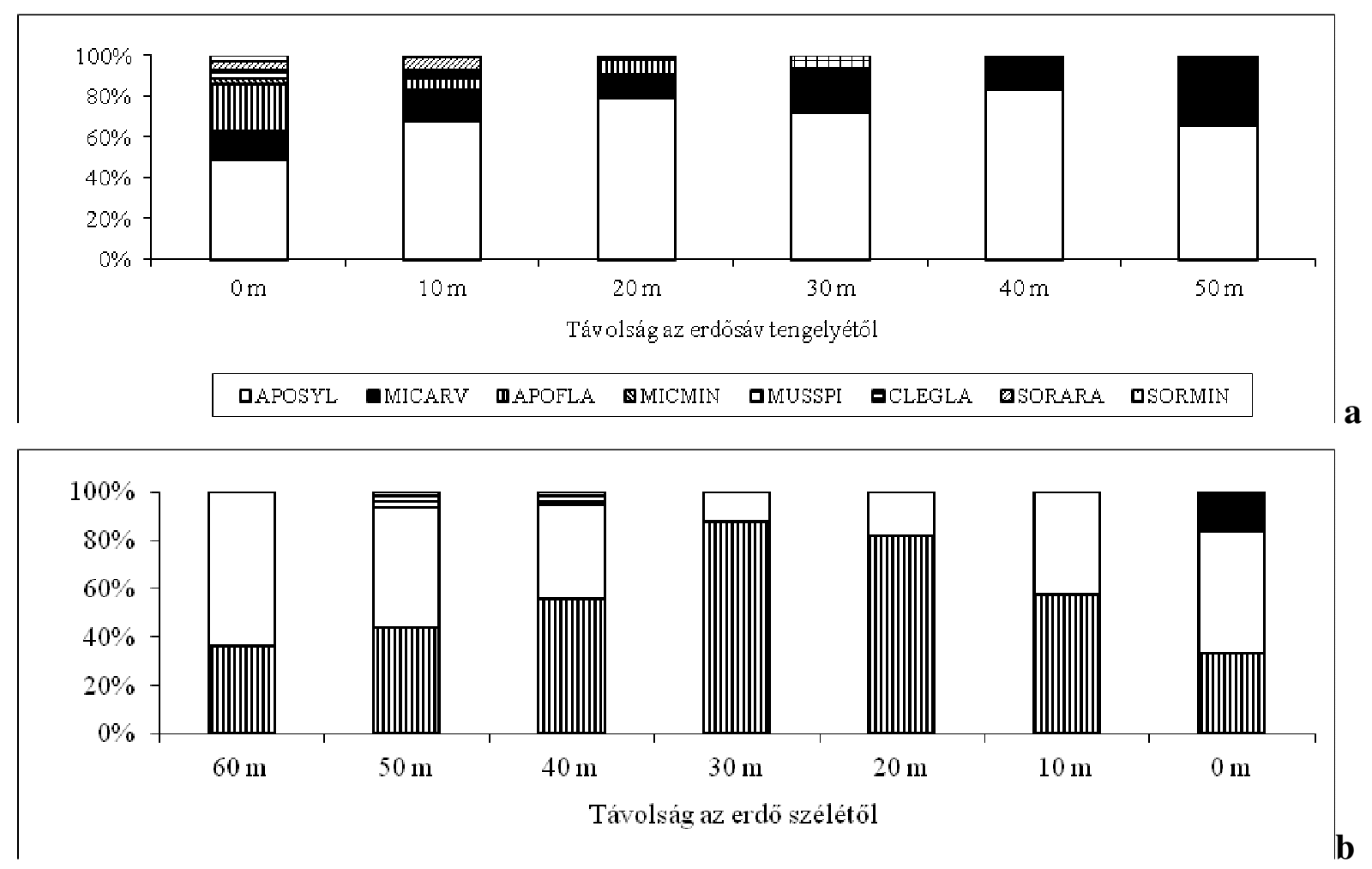

\section{3. ábra: Az erdősávos kvadrátok (a) és az akácos (b) kisemlős közösségének térbeli szerkezete (jelmagyarázatot lásd a 33/a ábrán)}

Figure 34: Spatial structure of forest belt quadrats' and black locust quadrat's small mammal community

Az erdősáv belsejében található két csapdasorban 7 faj fordult elő, a sávtól távolodva a fajszám egyértelmü csökkenést mutat, amely exponenciális trenddel jellemezhető $\left(r^{2}=0,9315\right)$. Ugyanez a jellemző az akácerdőben nem eredményez kimutatható trendet, a fajszám általában kisebb, egy csapdasorban 2-3 faj fordul elő (34. ábra).

A hektáronkénti denzitás értékek változását mutató 34/a ábra csökkenő tendenciáját az erdősávot és mezőgazdasági kultúrát egyaránt érintő kvadrátokban, a 20 méteres csapdasornál jelentkező denzitás-növekedés megtöri. Az ide tartozó növényzeti egységek elsősorban szegély élőhelyek (lucerna-vadföld, földút-tritikále), melyek valószínűleg az érvényesülő összegző szegélyhatás (GILES, 1978) következtében nagyobb egyedszámú kisemlőst képesek eltartani, mint a velük szomszédos erdősáv, ill. mezőgazdasági terület. A denzitás változásának trendje az erdősávos területen exponenciálisan csökkenő $\left(r^{2}=0,7872\right)$, szemben az akácossal, ahol a denzitás láthatóan nem mutat távolságfüggést (34/b ábra). Az akácerdőben a denzitás átlagos értéke 208 pd/ha az erdősávos kvadrátokban pedig 178 pd/ha. Az átlagok közti különbség nem szignifikáns ( $\mathrm{p}<0,05, \mathrm{t}=0,6060)$. 

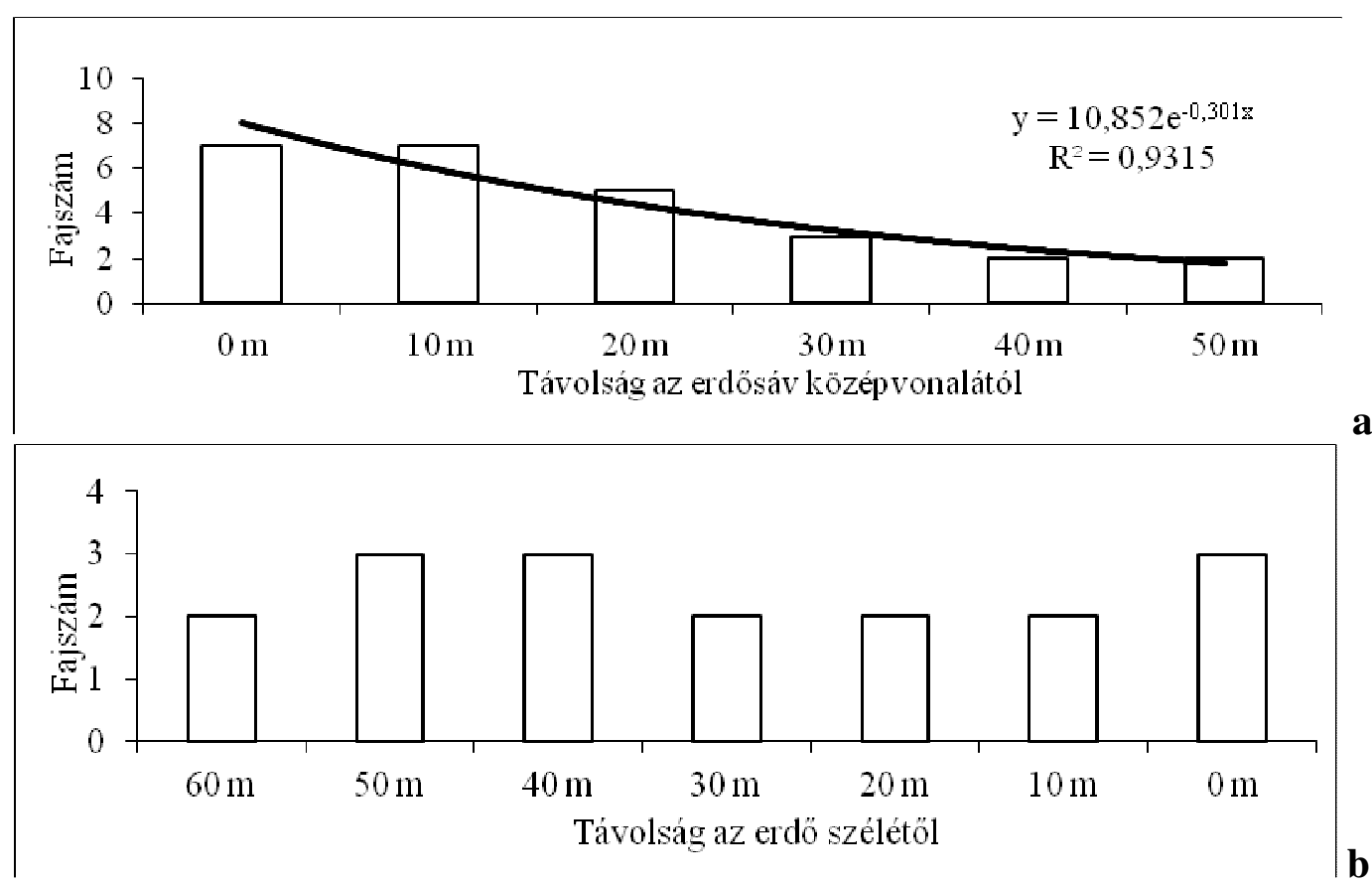

34. ábra: Az erdősávos kvadrátok (a) és az akácos (b) kisemlős közössége fajszámának térbeli alakulása

Figure 34: Spatial structure of species number of forest belt quadrats' and black locust quadrat's small mammal community

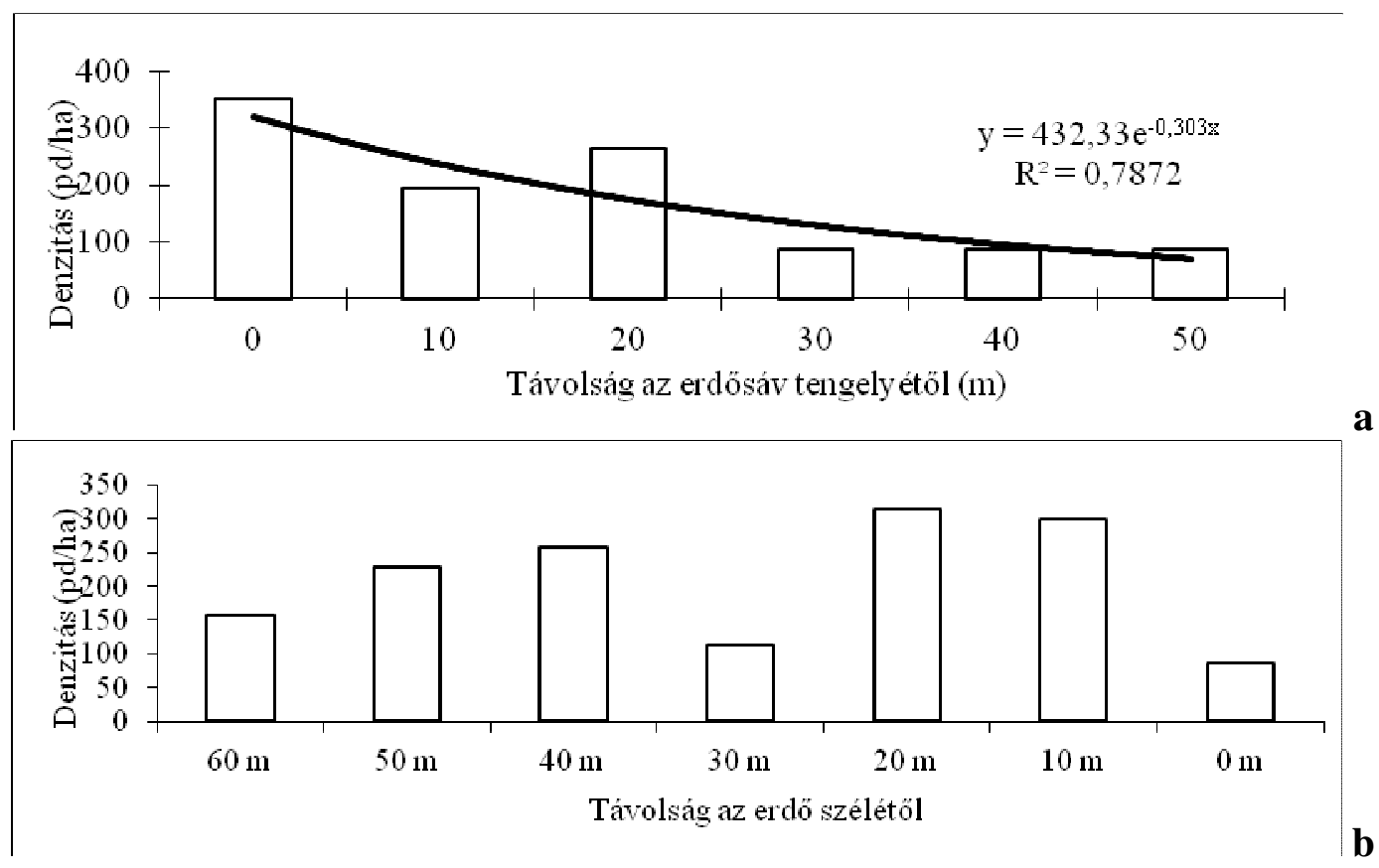

\section{5. ábra: Az erdősávos kvadrátok (a) és az akácos (b) kisemlős közössége denzitásának térbeli alakulása}

Figure 35: Spatial structure of density of forest belt quadrats' and black locust quadrat's small mammal community

A vizsgálataim szempontjából alapkérdésként felmerülő diverzitás alakulását a 36. ábra szemlélteti. Az erdősáv (36/a ábra) esetében a csökkenés iránya, mely lineáris regresszióval 
írható le $\left(\mathrm{r}^{2}=0,7795\right)$, itt is a mezőgazdasági terület felé mutat. Az akácerdő (36/b ábra) esetében nem ismerhető fel trend a csapdasorok kisemlős közösségeinek diverzitásai között.

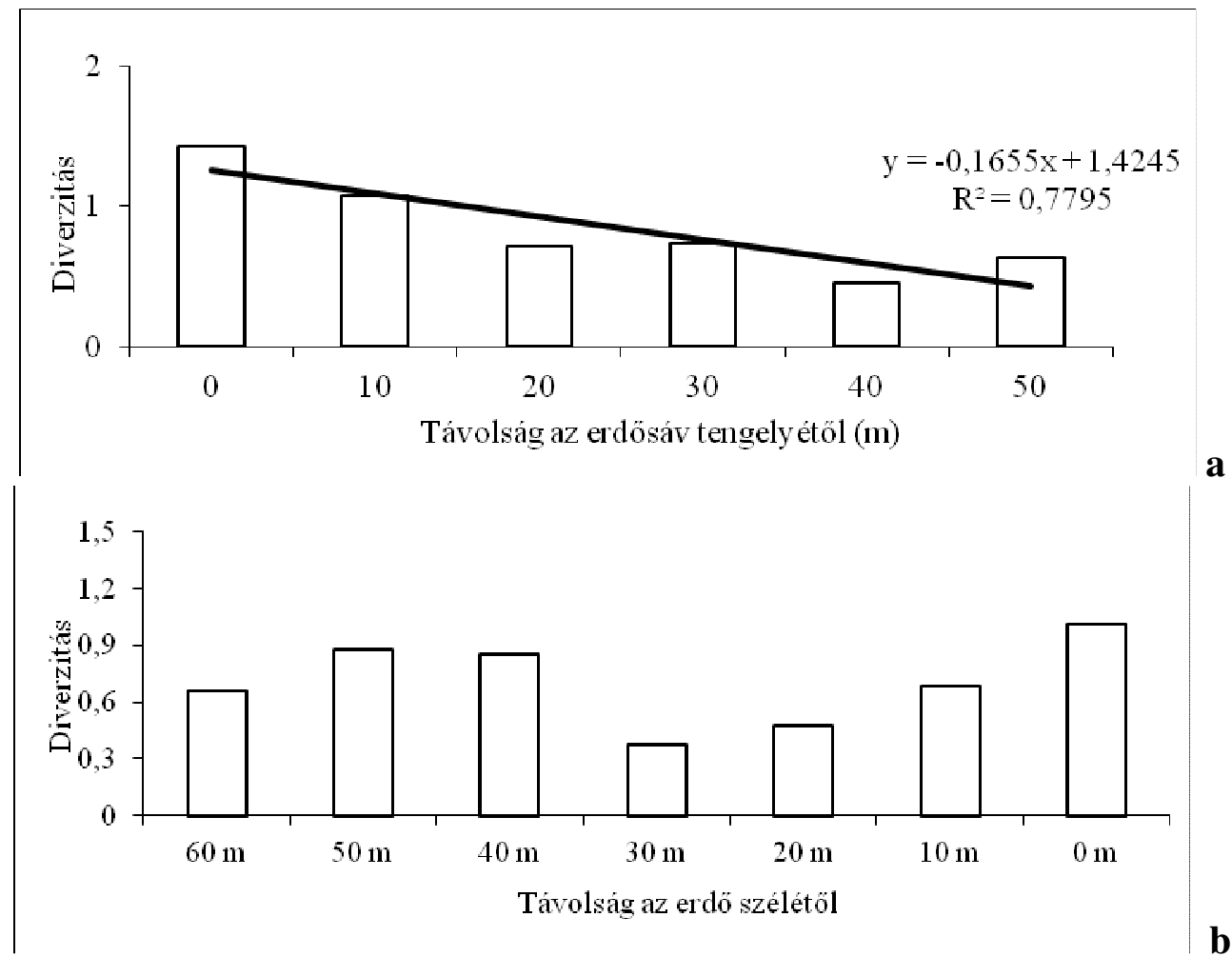

\section{6. ábra: Az erdősávos kvadrátok (a) és az akácos (b) kisemlős közössége diverzitásának térbeli alakulása}

Figure 36: Spatial structure of density of forest belt quadrats' and black locust quadrat's small mammal community

Az erdősávok rendszerének zöld folyosó szerepét a fentiekben említettek szerint a csatlakozó sávok közötti fajkicserélődés elemzésével vizsgáltam. A térképen üres körök jelzik a vizsgált erdősávokat. A sávok egymáshoz való kapcsolódását nyilak szemléltetik (19. térkép).

A nyilakkal összekapcsolt sávpárok (illetve ,sávhármasok”) évről-évre változó fajkészletét megvizsgálva kiszürhető, hogy vannak-e olyan fajok, melyek a sávpárok egyik részében később jelentek meg, mint a másikban, vagy a vizsgálati időszak alatt az egyikből eltüntek, míg a másikban továbbra is fennmaradtak.

A 9 sávpárból, ill. hármasból 5 esetében találtam a fent ismertetetteknek megfelelő fajkészletváltozást.

A Mosonszolnok 3C és 4A erdösávok közül a 3C-ben 1993-ban kimutatott közönséges erdeiegér a 4A-ban 1992-ben még nem volt jelen. 1994-re azonban ebben a sávban is megjelent (30. táblázat). 
30. táblázat: A Mosonszolnok 3C és 4A erdősávok fajkészletének változása

Table 30: Changes in the species collection of the Mosonszolnok 3C and 4A quadrats

\begin{tabular}{|c|c|c|c|c|c|c|}
\hline & 1992. & 1993. & 1994. & 1996. & 1997. & 1999. \\
\hline $3 C$ & & $\begin{array}{l}\text { APOFLA } \\
\text { APOSYL }\end{array}$ & & & & \\
\hline $4 \mathrm{~A}$ & $\begin{array}{l}\text { APOFLA } \\
\text { CLEGLA } \\
\text { MICARV }\end{array}$ & & $\begin{array}{l}\text { APOFLA } \\
\text { APOSYL } \\
\text { CLEGLA } \\
\text { MICARV } \\
\text { SORMIN }\end{array}$ & APOSYL & $\begin{array}{l}\text { APOFLA } \\
\text { APOSYL } \\
\text { MICARV } \\
\text { SORARA } \\
\text { MUSSPI }\end{array}$ & $\begin{array}{l}\text { APOFLA } \\
\text { APOSYL } \\
\text { MICARV } \\
\text { SORARA } \\
\text { SORMIN }\end{array}$ \\
\hline
\end{tabular}

A Mosonszolnok 3E és 4C erdősávok esetében a mezei pocok 3E erdősávban való 1996. évi megjelenése lehetséges, hogy a 4C erdősávban már 1992-ben ismertté vált mezei pocok közösség egyedeinek köszönhető, bár ez a faj föként az erdősávokat körülvevő kultúrsztyepp lakója, és az erdősávokba elsősorban innen telepszik be. Ugyanakkor a közönséges erdeiegér 3E erdősávból való eltünése nem járt együtt a faj sávpárosból való kipusztulásával, hiszen a faj a 4C erdősávban 1994-től 1999-ig folyamatosan kimutatásra került (31. táblázat).

31. táblázat: A Mosonszolnok 3E és 4C erdősávok fajkészletének változása

Table 31: Changes in the species collection of the Mosonszolnok 3E and 4C quadrats

\begin{tabular}{|c|c|c|c|c|c|c|}
\hline \multicolumn{2}{|r|}{1992.} & 1993. & 1994. & 1996. & 1997. & 1999. \\
\hline $3 E$ & & $\begin{array}{l}\text { APOFLA } \\
\text { APOSYL }\end{array}$ & & $\begin{array}{l}\text { APOFLA } \\
M I C A R V\end{array}$ & & \\
\hline $4 \mathrm{C}$ & $\begin{array}{l}\text { APOFLA } \\
\text { APOSYL } \\
\text { CLEGLA } \\
\text { MICARV } \\
\text { SORARA }\end{array}$ & & $\begin{array}{l}\text { CLEG } \\
\text { CROI } \\
M I C A \\
\end{array}$ & $\begin{array}{l}\text { APOFLA } \\
\text { APOSYL } \\
\text { CLEGLA } \\
\text { MICARV }\end{array}$ & $\begin{array}{l}\text { APOSYL } \\
\text { CLEGLA } \\
\text { MICARV } \\
\text { MUSSPI }\end{array}$ & $\begin{array}{l}\text { APOFLA } \\
\text { APOSYL } \\
\text { MICARV } \\
\text { SORARA } \\
\text { MUSSPI }\end{array}$ \\
\hline
\end{tabular}

A Mosonszolnok 3F-3G-4D sávhármasban a közönséges erdeiegér terjedése figyelhető meg. A faj 1992-ben a 3F akácosban vált ismertté, majd 1993-ban a 4D erdősávból is kimutatásra került. Ezt követően, 1994-ben jelent meg a 3G jelü erdősávban (32. táblázat).

A Jánossomorja 69B és 69C sávok közül, az elöbbiben már 1992-ben jelen volt a vöröshátú erdeipocok, a 69C-ben azonban csak 1997-ben jelent meg (33. táblázat).

A Jánossomorja 70B, 70C és 70D sávok közül a 70B-böl 1992-ben még hiányzott a vöröshátú erdeipocok, 1993-ra azonban itt is megjelent. 1993. és 1996. között az említett fajjal együtt a sárganyakú erdeiegér is eltünt, a 70D erdősávban azonban 1997-ben ismét elökerültek (34. táblázat). 
32. táblázat: A Mosonszolnok 3F, 3G és 4D erdősávok fajkészletének változása

Table 32: Changes in the species collection of the Mosonszolnok 3F, 3G and 4D quadrats

\begin{tabular}{|c|c|c|c|c|c|c|}
\hline & 1992. & 1993. & 1994. & 1996. & 1997. & 1999. \\
\hline $3 \mathrm{~F}$ & $\begin{array}{l}\text { APOFLA } \\
\text { APOSYL } \\
\text { CLEGLA } \\
\text { CROLEU } \\
\text { MICARV }\end{array}$ & APOFLA & $\begin{array}{l}\text { APOFLA } \\
\text { APOSYL } \\
\text { CLEGLA } \\
\text { MICARV }\end{array}$ & & $\begin{array}{l}\text { APOFLA } \\
\text { APOSYL } \\
\text { MICARV }\end{array}$ & $\begin{array}{l}\text { APOFLA } \\
\text { APOSYL } \\
\text { CLEGLA } \\
\text { MICARV }\end{array}$ \\
\hline $3 \mathrm{G}$ & $\begin{array}{l}\text { APOFLA } \\
\text { CLEGLA } \\
\text { MICARV } \\
\text { SORARA }\end{array}$ & & $\begin{array}{l}\text { APOFLA } \\
\text { APOSYL } \\
\text { CLEGLA } \\
\text { MICARV } \\
\text { SORMIN } \\
\text { MICMIN }\end{array}$ & $\begin{array}{l}\text { APOSYL } \\
\text { MICARV }\end{array}$ & $\begin{array}{l}\text { APOSYL } \\
\text { MICARV } \\
\text { SORARA }\end{array}$ & $\begin{array}{l}\text { APOFLA } \\
\text { APOSYL } \\
\text { CLEGLA } \\
\text { MICARV } \\
\text { SORARA } \\
\text { SORMIN } \\
\text { MICMIN } \\
\text { MUSSPI } \\
\end{array}$ \\
\hline $4 \mathrm{D}$ & & $\begin{array}{l}\text { APOFLA } \\
\text { APOSYL } \\
\text { MICARV }\end{array}$ & & & & \\
\hline
\end{tabular}

33. táblázat: A Jánossomorja 69B és 69C erdősávok fajkészletének változása

Table 33: Changes in the species collection of the Jánossomorja 69B and 69C quadrats

\begin{tabular}{|c|c|c|c|c|c|c|}
\hline & 1992. & 1993. & 1994. & 1996. & \begin{tabular}{|l}
1997. \\
.
\end{tabular} & 1999. \\
\hline 69B & $\begin{array}{l}\text { APOFLA } \\
\text { APOSYL } \\
\text { CLEGLA } \\
\text { MICARV } \\
\text { SORARA }\end{array}$ & & $\begin{array}{l}\text { APOFLA } \\
\text { APOSYL } \\
\text { MICARV }\end{array}$ & & $\begin{array}{l}\text { APOFLA } \\
\text { APOSYL } \\
\text { MICARV } \\
\text { SORARA }\end{array}$ & \\
\hline $69 \mathrm{C}$ & $\begin{array}{l}\text { APOFLA } \\
\text { APOSYL } \\
\text { MICARV }\end{array}$ & & $\begin{array}{l}\text { APOFLA } \\
\text { APOSYL } \\
\text { MICARV }\end{array}$ & & $\begin{array}{l}\text { APOFLA } \\
\text { APOSYL } \\
C L E G L A \\
\text { MICARV } \\
\text { PYTSUB }\end{array}$ & \\
\hline
\end{tabular}


34. táblázat: A Jánossomorja 70B, 70C és 70D erdősávok fajkészletének változása

Table 34: Changes in the species collection of the Jánossomorja 70B, 70C and 70D quadrats

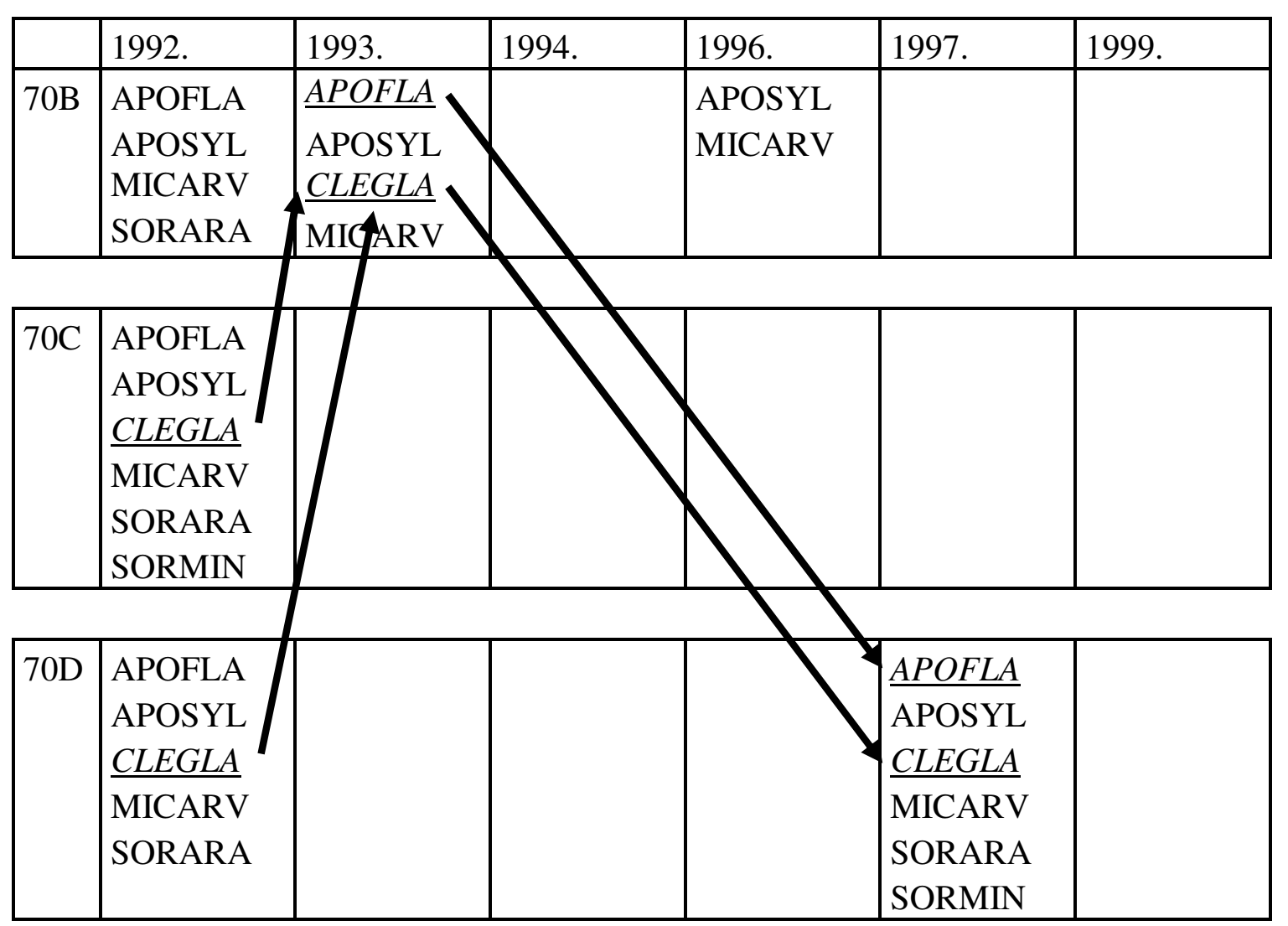

\section{MEGVITATÁS}

\subsection{A kisemlős populációk jellemzőinek összehasonlítása}

\section{Diszperzió és élőhelyhasználat}

A LAJTA Project területén vizsgált 23 erdősávból 11 talajlakó, rovarevő és rágcsáló kisemlős faj jelenlétét mutattam ki. A legelterjedtebb kisemlős faj a közönséges erdeiegér volt, mely az erdősávok 96\%-ában előfordult. A második leggyakoribb faj a sárganyakú erdeiegér (91\%), míg a mezei pocok az erdősávok 83\%-ában, a vöröshátú erdeipocok pedig 74\%-ában fordult elő. Ugyanezt a sorrendet tapasztaltam a mikrohabitat használat tekintetében is: a közönséges erdeiegér bírt a legszélesebb spektrummal (100\%), a másik Apodemus faj a mikrohabitatok 74\%-át, a mezei pocok 52\%-át használta. Mindhárom faj esetében elmondható, hogy mikrohabitatok közti eloszlásuk nem bizonyult egyenletesnek: a közönséges erdeiegér leginkább a takarmánylucerna, angolperje és betyárkóró növényfajokkal jellemezhető élőhelyet preferálta, míg legkisebb denzitással a homogén lucernásban volt kimutatható. A sárganyakú erdeiegér fogott mennyiségének $1 / 5$ része a zárt akácos kinincs csertjeszinttel, réti perje, fedél rozsnok és piros árvacsalán alkotta gyepszinttel jellemezhető élőhelyéröl került elö, a homogén lucernásban, kukoricásban és a tárcsázott borsótarló területén azonban egy példányát sem sikerült csapdázni. A mezei pocok által preferált mikrohabitatot angolperje, közönséges tarackbúza, közönséges aszat és betyárkóró alkotta, a homogén kukoricásból és a tárcsázott borsótarlóról pedig egyáltalán nem volt kimutatható a faj. A zárt akácos szélén is 
csupán egy példánya jelent meg. A vöröshátú erdeipocok 1999-es alacsony fogásszáma ezt a vizsgálatot nem tette lehetővé, azonban nem kétséges, hogy éppen a négy faj közt elfoglalt legritkább helyzete okán, a legszűkebb spektrumát használja az erdősávos agrárterület mikrohabitatjainak.

A ritka fajok között három Soricida, az erdei, a mezei és a törpecickány volt jelen, a JÁNOSKA (1995a) által bagolyköpetböl kimutatott Crocidura suaveloens (PALLAS, 1811) valószínüsíthetően eltérő élőhelyigénye miatt nem került csapdába. Az erdei cickány dominancia értéke $(2,5 \%)$ meghaladta az összes többi ritka faj összdominanciáját $(2,2 \%)$. A törpeegér, a güzüegér, a közönséges hörcsög és a földipocok egyaránt alacsony fogásszámmal szerepeltek a vizsgálatokban.

A fentiek alapján a mezővédő erdősávos agrárterület vonatkozásában elmondható, hogy rajtuk, a mezei élőhelyek általánosan elterjedt rágcsálófaján (mezei pocok, közönséges hörcsög) túl, állandó népessége alakult ki a közönséges és sárganyakú erdeiegérnek, valamint a vöröshátú erdeipocoknak is. Az utóbbi három faj az európai, mérsékelt övi erdők generalista rágcsálója (HORVÁTH \& LANSZKI, 2000), és mint ilyenek egyértelműen jelzik a mezővédő erdősávoknak az agrárterületek kisemlős fajdiverzitásának növelésében betöltött pozitív szerepét. A három fajból a közönséges erdeiegér a mezei pocok konkurenseként (KöLÜs, 1969) a teljes területen elterjedt, minden mikrohabitatban előfordult, jelentősen szükítve a mezei pocok élőhelyspektrumát. A másik Apodemus faj szorosabb kötődést mutat a fásszárú vegetációval is borított élőhelyekhez, amit föként az akácosban -amely a terület élöhelyei közül leginkább követi a természetes erdők struktúráját- tapasztalt magas denzitása bizonyít.

A vöröshátú erdeipocok az évek során szintén az akácosból, valamint a diverz élőhelyszerkezettel jellemezhető erdősávokból került kimutatásra. Utóbbi két faj erdősávokban való megjelenését a fa- és cserjefajok borításának hatására kialakuló táplálékkínálat növekedéssel, és a szintén ezeknek köszönhető mikroklimatikus hatásokkal magyarázom. Az erdei fák és cserjék magja e fajok táplálékának meghatározó részét képezi (NAGY, 1980). Ilyen tekintetben különbséget találunk a két erdeiegér faj között: a közönséges erdeiegér magfogyasztásában a füfélék, míg a sárganyakú erdeiegérében a fásszárúak magja dominál (CORBET \& OVENDEN, 1982). A táplálék mellett, a fásszárú vegetáció klimatikus tekintetben is eltér az agrárterülettől. A mezővédő erdősávok csökkentik a szél erejét és az elpárolgást, növelik a levegő relatív légnedvességét, fokozzák a harmatképződést, hőmérséklet kiegyenlítő hatásuk van (GÁL \& KÁLDY, 1977, WILDERMUTH nyomán BIBER, 1988). A fentiek közül a kisemlősök szempontjából véleményem szerint a hőmérséklet kiegyenlítő hatásuk emelendő ki, tekintettel arra, hogy a kontinentális klímazónában az állandó testhőmérséklet fenntartásának éppen a kis testméret miatt fokozott energiaigénye van (REICHHOLF, 1992). Különösen igaz ez a Soricidákra, melyek közül az erdei cickány 2,5\%-os erdősáv-beli előfordulását, a korábbiak tükrében, szintén hangsúlyosnak tartom.

\section{Ivararány és annak változása}

A négy domináns rágcsáló faj tekintetében a teljes vizsgálati időszakban hím többséget sikerült kimutatni, mely a pocokfajoknál érte el a legnagyobb értéket (mezei pocok 76\%, vöröshátú erdeipocok $71 \%$ ). Az ivararány egy vegetációs perióduson belüli változásának vizsgálatára a két erdeiegér fajnál volt lehetőség. A közönséges erdeiegér esetében mind a négy vizsgált kvadrátban, júliusban kaptam a legnagyobb ivararány (hím/nőstény) értékeket, melyek közül a 3F és 4A kvadrátokban számított érték hím többséget, a 3G és 4C kvadrátokban pedig 1:1 körüli arányt mutat. Az arányszámok augusztusra mind a négy területen csökkentek, de az előbbi két kvadrátban továbbra is megmaradt a hím többség. Szeptemberre a 3F kvadrát kivételével mindhárom élőhelyen kiegyenlítődött az ivararány, 
míg az akácosban a hímek aránya nőtt. Az ivararány változások trendje közti korreláció tteszt alapján a 3F-4A és a 3F-4C kvadrátok vonatkozásában volt szignifikáns. A sárganyakú erdeiegér esetében az alacsony fogási értékek miatt csak a $3 \mathrm{~F}$ akácos kvadrátjára tudtam a fenti összehasonlítást elvégezni. Itt a közönséges erdeiegérével éppen ellentétes irányú változásokat regisztráltam. A jelentős júliusi nőstény többség, augusztusra a hímek arányának növekedését hozta, majd augusztus és szeptember között a folyamat ismét megfordult, a hím többség azonban megmaradt.

Összefoglalva az ivararány és annak változása tekintetében tapasztaltakat megállapítható, hogy a teljes vizsgálati időszakban tapasztalt hím többség ugyan több év összesített eredményéből származik, és e tekintetben reprezentatív, ám ismerve az ivararány éven belüli dinamikájából megvizsgált három hónap jelentős változásait, nem enged általánosítható következtetést a populációk ivari szerkezetére vonatkozóan. A különböző élőhelyek ivararány változásának szignifikáns hasonlóságát a viszonylag rövid, három hónapos vizsgálati időszak miatt - HORVÁTH \& KALMÁR (2001) eredményeinek ismeretében - szintén nem kívánom túlhangsúlyozni. Kiemelendő eredménynek tartom azonban, hogy a 3F kvadráttal vizsgált akácosban a két Apodemus faj ivararánya éppen ellentétesen változik. A jelenséget a két faj versengésének következtében kialakult dinamikus egyensúlyi helyzet pillanatnyi állapotaként értékelem. Ezt az eredményezi, hogy az egyik faj graviditásainak időszakában annak nőstényei ritkábban hagyják el otthonaikat, mint a hímek, így ennél a fajnál a csapdákban megnő a hímek aránya. A laktálási intenzitás csökkenésével aztán a nőstények is többet mozognak, melynek következtében a csapdákból kimutatott ivararány a javukra változik. Öszi időszakban e folyamathoz hozzájárul a hímek vándorlási hajlamának növekedése, ami tovább javítja a nőstények arányát a csapdázásokban. Véleményem szerint a források optimális hasznosításának kényszere miatt a két faj szaporodási ciklusa az akácosban úgy tolódott el egymáshoz képest, hogy az előzőekben részletezett, populáción belül szinkronizált létszám-növekedés a két fajnál eltérő időszakban következik be.

\section{Az egyedszám dinamikája}

Egy vegetációs perióduson belül két faj fogási eredményei voltak a hónapok és a kvadrátok viszonylatában összehasonlíthatók.

A közönséges erdeiegérnél 3 kvadrátban augusztusi, egyben szeptemberi létszám maximum alakult ki. Az egy csapdára jutó átlagos fogásszámok közül a 3F akácosban az augusztusi maximum volt szignifikáns, a 4C-ben pedig a szeptemberi denzitás volt szignifikánsan nagyobb a júliusinál. Az egyes kvadrátok összehasonlítása kimutatta, hogy a 4C-ben kialakult szeptemberi maximum mindhárom másik kvadrát szeptemberi denzitását szignifikánsan meghaladta.

A sárganyakú erdeiegér a vizsgálatok alapján a 3F akácosban, augusztusban nagyobb denzitással szerepelt, mint júliusban, a 3G-ben, augusztusi, a 4C-ben szeptemberi maximuma volt szignifikáns. A kvadrátok egymással való összehasonlítása szerint augusztus hónapban, a 3F kvadrátban szignifikánsan több egyed fordult elö, mint a másik három helyen, szeptemberben pedig a $4 \mathrm{~A}$ és a $3 \mathrm{G}$ kvadrátban tapasztalt denzitást haladta meg a $3 \mathrm{~F}$ akácos populációja.

Az évek közti dinamika összehasonlítására az egyes évek ugyanazon szakaszában (július-augusztus) történt csapdázások adtak lehetőséget.

A közönséges erdeiegér 100 csapdaéjszakára jutó fogásszáma a 3G és 4A erdősávban lineárisan nőtt 1992. és 1999. között. A 3F akácosban a trend másodfokú görbével volt közelíthető, maximumát, mely a sávok közti maximum is egyben, 1997-ben mutatta. A 4C erdősáv eredményeire nem lehetett trendvonalat illeszteni. 
A sárganyakú erdeiegér egyedszám változása 1992-től csökkenő trendet mutat, mely a 4A és 3G sávokban 1996-ban éri el mélypontját. Az időszak végére növekedés tapasztalható, a változás csak egy esetben (4C) közelíthető regresszióval.

A vöröshátú erdeipocok egyedszám változása mind a négy vizsgált erdősávban csökkenő, trendje logaritmikus regresszióval közelíthető.

A mezei pocok egyedszám változása nem írható le trendfüggvénnyel. A 3G, 4A és 4C sávokban 1992. és 1996. között a fogásszám csökken, majd 1997-re elér egy helyi maximumot, végül 1999-ben ismét minimálisra csökken.

A dinamika tekintetében a fentiek alapján kirajzolódik, hogy a közönséges és a sárganyakú erdeiegér 1999. július és szeptember között augusztusi vagy szeptemberi maximumot mutatott. Az vizsgálati évek között a két faj ellentétes irányú létszámváltozását tapasztaltam, ami egybevág az ivararány változásánál kapott eredménnyel.

A vöröshátú erdeipocok populációk vizsgált időszak során tapasztalt összeomlása nem egyedi jelenség, tekintve, hogy HORVÁTH a Dráva menti erdőterületen is tapasztalt hasonló jelenséget (szóbeli közlés).

A mezei pocok két-háromévente ismétlődő gradációs hullámzása a területen tapasztaltak alapján is megerösítést nyert.

\section{Foltosság}

A Lloyd-féle foltosság vizsgálata alapján elmondható, hogy az erdeiegér fajok állományai többségében aggregáltságot (17, ill. 8 esetben) mutattak, míg a pocokfajoknál a szegregáltságot mutató populációk voltak többségben (8, ill. 4 esetben). Mivel a csapdázások döntő részben erdősávok területén folytak, az Apodemus fajok aggregálódásának oka az erdősáv táplálék és búvóhely koncentráló szerepe lehet, míg az Arvicolidae fajok esetében ez - a fásszárúak magjának kisebb mértékü fogyasztása miatt - kevésbé hat az egyedek csoportosulására.

A foltosság denzitásfüggését egyik fajnál sem sikerült kimutatni. Az utóbbi eredménynél azonban mindenképpen megjegyzendő, hogy a kis mintaszám miatt alkalmazott összevonások (különböző vizsgálati helyek különböző évekből származó adatai) erősen zavarhatták a ponthalmaz eloszlását.

\section{Testtömeg és dinamikája}

A két erdeiegér faj esetében egyaránt 1997-ben tapasztaltam az átlagos testtömeg maximumát, ami szignifikánsnak is mutatkozott. A pockok esetében az 1999. év eredményei szolgáltatták a legnagyobb értéket, amely a mezei pocoknál mindkét előző évit, a vöröshátú erdeipocoknál csak az 1992-ben mértet haladta meg szignifikánsan. A vöröshátú erdeipocoknál az alkalmazott teszt értelmezhetőségét azonban gyengíti, hogy jelentősen eltérő minta elemszámok szerepeltek az összehasonlításban (100, 11 és 8).

A testtömeg alakulását a rendelkezésre álló táplálékforrás mennyisége és minősége határozza meg. A vizsgálati évek ugyanazon szakaszában tapasztalt testtömeg értékek különbözőségét, feltételezve, hogy az ivari és a koreloszlás hasonló, leginkább a döntő részt növényi táplálékbázis eltérő minősége okozhatja. Ez alapvetően időjárási tényezőkre vezethető vissza. Anélkül, hogy erre vonatkozó vizsgálatokat végeztem volna, feltételezhető, hogy a maximális testtömeg értékeket adó években alakult a leginkább optimálisan az egyes kisemlős fajok tápnövényeinek fejlödése.

A teljes vizsgálati időszak populációkra jellemző átlagértékei több faj, így az Apodemus sylvaticus, Sorex araneus, Clethrionomys glareolus esetében az irodalomból 
(CORBET \& OvENDEN, 1982) ismert értékeknél alacsonyabbak vagy azok alsó határát közelítik. Ennek magyarázata a földrajzi változatosság, ill. a csapdázott egyedek koreloszlása (sok juvenilis egyed) lehet.

\subsection{A kisemlős közösségek szerkezetének összehasonlítása}

\section{A fajszám, fajkészlet és egyedsürüség összehasonlítása}

Vizsgálataimban 23 erdősáv kisemlős közösségének fajszám, denzitás, egyenletesség és diverzitás értékeit határoztam meg. A kapott eredményekből kijelenthető, hogy a vizsgált agrárterület erdősávjaiban átlagosan 3-6 kisemlős faj alkot közösséget. A fajszám és 100 csapdaéjszakára jutó egyedszám értékei az 1992-es és az 1999-es évben mutatták a legnagyobb értékeket, míg a legkevesebb fajt, ill. egyedet 1993-ban és 1996-ban csapdáztam. Kiemelendőnek tartom, hogy a vizsgált sávok kisemlős fajkészlete az évek során jelentős változásokat mutatott. A négy leggyakoribb fajból a közönséges és a sárganyakú erdeiegér volt állandó tagja a közösségeknek, míg a mezei pocok és a vöröshátú erdeipocok több esetben egy-egy évre, vagy évekre eltűnt az erdősávokból. Fajszám szempontjából a Mosonszolnok 4C, és a Jánossomorja 70A sávok voltak a legstabilabbak, bennük a fajszám legfeljebb eggyel változott pozitív, ill. negatív irányba. Fajkészlet tekintetében a $13 \mathrm{db}$, legalább három különböző évben vizsgált erdősáv közül 7 esetében (Mosonszolnok 3I, 4C, Jánossomorja 68C, 69B, 69C, 69F, 70A) volt kimutatható minden alkalommal ugyanaz a három faj.

A 100 csapdaéjszakára jutó egyedszám legnagyobb értéke (43,33) 1992-ben a 3I jelü erdősávra volt jellemző, a minimumot pedig 1993-ban, a 3F akácosban mutattam ki $(0,67)$.

Fentiek alapján kiemelendőnek tartom a Mosonszolnok 3I erdősáv fajkészletstabilitását és egyedszám maximumát. Véleményem szerint ez a dús cserjeszintủ, jól záródott lombozattal rendelkező erdősáv nyújtja a legoptimálisabb feltételeket a stabil, magas faj- és egyedszámú kisemlös közösség számára. Az elemzett adatsoraim jelentőségét abban is látom, hogy összehasonlítási alapot jelentenek más, erdősávokban vagy természetszerü élőhelyeken folytatott vizsgálatok eredményeivel.

\section{Dominancia viszonyok és azok változása}

Az erdősávonkénti elemzés alapján általánosságban elmondható, hogy az 1992. és 1999. közötti időszak elsősorban a közönséges erdeiegér dominanciájának növekedését eredményezte a vizsgált erdősávok kisemlős közösségeiben. A periódus végén a 14 erdősávból 9-ben az említett faj vált dominánssá. A közönséges erdeiegér mellett föként a mezei pocok állománya tudott megerösödni -14 erdősávból négyben-, ill. a 3F jelü akácos területén a sárganyakú erdeiegér vált az időszak végére dominánssá. Feltünő, hogy az időszak elején 4 területen domináns vöröshátú erdeipocok 1999-re, ill. 1997-re drasztikusan visszaszorult. Kiemelendő, hogy a 3I jelü erdősáv kisemlős közösségének szerkezete, a többi vizsgált élőhelytől eltérően kis kilengésekkel jellemezhető állandóságot mutatott.

Az egy vegetációs perióduson belüli vizsgálatok eredményei szerint a közönséges erdeiegér júliusi dominanciáját figyelhetjük meg mind a négy kvadrátban. A faj domináns jellege három helyen szeptemberig fennmarad, a mezei pocok kismértékü erősödése mellett. A 3F jelü akácosban azonban a sárganyakú erdeiegér fokozatosan visszaszorította az előbbi Apodemus fajt, és szeptemberre nagyobb arányú dominanciát mutatott, mint júliusban a közönséges erdeiegér. 
A vizsgált erdősávok kisemlős közösségeiröl eredményként megállapítottam, hogy bennük elsősorban a közönséges erdeiegér dominanciája jellemző, mellyel leggyakrabban a mezei pocok verseng. Lényeges eredménynek tartom a 3I erdősávban kimutatott, több éven át fennálló egyensúlyi állapotot a dominanciák tekintetében, ami véleményem szerint a négy rágcsálófaj számára egyaránt optimális habitatszerkezetre utal. A Mosonszolnok 3I erdősávban valószínüleg hasonló arányban található meg mind a négy faj számára a szükséges mikrohabitat. Ezzel magyarázható, hogy egyik faj sem tud a többi rovására létszámfölénybe kerülni.

A 3F akácosban tapasztaltak rámutatnak arra, hogy azokban a lomberdőkben, ahol a mezei pocok nem jellemző tagja a kisemlös közösségnek, a két erdeiegér faj versengése hasonló erélyü, mint az a nyílt területeken tapasztalható a mezei pocok és a közönséges erdeiegér esetében.

\section{Diverzitás, egyenletesség és azok változása}

Részletesen foglalkoztam a kisemlős közösségek diverzitásának elemzésével. Közösségi ökológiai vizsgálatokban ez a kérdés hagyományosan hangsúlyos jelentőséggel szerepel, ugyanakkor állandó viták tárgya az eredmények értelmezése (TóTHMÉRÉSZ, 1998). A sokféleséget egyszerüen származtató mennyiségek, mint például a fajszám, vagy a különböző diverzitási képletek (kvadratikus, Shannon, Brilluen, stb) két közösség esetében gyakran eltérö besorolást eredményeznek. Ezt részben kiküszöbölendö, ugyanazon élöhelyek több időpillanatban regisztrált kisemlős közösségei sokféleségének összehasonlítására, többlépcsős eljárást választottam. Először a legáltalánosabban alkalmazott Shannon-féle diverzitást számoltam ki, melynek fajbőség (richness) komponense a fajszámot, egyenletesség (eveness) komponense pedig az egyedek fajok közti eloszlását veszi figyelembe. Az így kapott értékeket t-teszttel vetettem össze. Ahol a t-teszt szignifikáns eltérést jelzett az értékpárok között, ott a diverzitás skálafüggő jellemzésére szolgáló Rényi-féle diverzitási rendezést is elvégeztem. Az egymás diverzitási profilját nem metszö diverzitási görbék esetében tekintettem az összehasonlított közösségeket diverzitás szerint rendezhetőnek, valamint diverzebbnek azt a közösséget, melynek görbéje fentebb futott. Amennyiben a közösségek profiljai a kezdőértéknél találkoztak, faj-abundancia görbéik alapján is megvizsgáltam viszonyukat.

Mindezek alapján elmondható, hogy a 3F, 3G, 4A, 4C jelü területeken 1992-ben és 1994-ben tapasztaltam a legdiverzebb közösségeket, ami egybevág a fajszám és a denzitás alapján kapott eredménnyel. Egy éven belül az akácosban a júliusi diverzitás szignifikánsan kisebb volt a következö két havinál, a 3G-ben pedig a júliusi haladta meg a szeptemberit. Eredményeim megerösítik, hogy kisemlős közösségek összehasonlító vizsgálatát csak többéves csapdázások eredményeire támaszkodva célszerü értékelni.

\subsection{Kapcsolat a közösségek szerkezete és az élőhelyszerkezet között}

Az egyes kisemlős fajok elterjedési és állományviszonyai között részletezett mikrohabitat vizsgálatok kimutatták, hogy a kisemlősök bizonyos mikrohabitatokat előnyben részesítenek, míg másokat kevésbé használnak. A habitatok vegetációja a kisemlősök számára táplálékul és búvóhelyül egyaránt szolgál. Ebből kiindulva feltételezhetnénk, hogy a habitatokra vegetációjuk szerkezetének, ill. karakterisztikáinak megfelelő összetételü kisemlős közösségek jellemzőek. Ugyanakkor a mezővédő erdősávok, mint kisemlős habitatok, több szempontból is speciális élőhelyek: 
Térbeli kiterjedésük sávszerü, szélességük csupán 10-30 m. A kisemlösök által használt gyepszintjük homogén, általában néhány fajból áll, melyek borítása az erdősáv hossztengelye mentén lényegében nem változik.

Szegély élőhelyek, mivel két vagy több habitat találkozásánál létesültek (esetenként egy 3-4m széles mezei út kíséri őket, melyet keskeny gyomsáv követ, majd utána mezőgazdasági kultúra következik mindkét oldalon).

A szomszédos mezőgazdasági kultúrák eltérő táplálékbázist biztosítanak a kisemlősöknek, mely általában homogén, azonban a betakarítással, talajműveléssel rapszódikusan változik. Mindezekkel összefüggésben a mezőgazdasági kultúrák maguk is állandó élőhelyei kisemlősöknek, melyek hatással vannak az erdősáv kisemlős közösségének alakulására is.

Figyelembe véve a fentieket, valamint a már kifejtett vizsgálati eredményeket a közösségek dinamikájára vonatkozóan, úgy vélem nem volna helyes annak a hipotézisnek a „minden áron való” igazolása, hogy valamely mérhető habitatjellemző, vagy abból származtatott mérőszám szoros összefüggést mutat a közösségek mindenkori szerkezetével. Vizsgálataimban eleve árnyaltabb kapcsolatot feltételezve arra fektettem hangsúlyt, hogy csapdázási időszakonként egymással hasonlítsam össze az erdősávok kisemlős közösségeit, valamint ezzel párhuzamosan a habitatok szerkezetét (melyet az évek során állandónak tekintettem). Így a mindkét szempontból egy hasonlósági csoportba került erdősávokról kijelenthető, hogy szerkezetük és az adott évben bennük élő kisemlős közösség egyaránt hasonló volt. A vizsgálati időszakonként hasonlónak bizonyult erdősáv-párok között annál erősebbnek tekintettem a hasonlóságot, minél több periódusban kerültek egymás mellé.

Eredményül a $4 \mathrm{C}-3 \mathrm{G}$ páros 4 , a $3 \mathrm{~F}-4 \mathrm{C}$ és a $70 \mathrm{~B}-4 \mathrm{~A}$ 2-2 periódusban kimutatott hasonlóságát kaptam. Mindez azt jelenti, hogy ezekben az élőhelypárokban, különböző élőhelyekkel való összehasonlítások alkalmával, több időszakon keresztül, hasonló kisemlős közösséget és egyben hasonló vegetáció szerkezetet sikerült kimutatni. Hasonló trendet találtam a mozaikosság mérőszámaként ismert $\beta_{\mathrm{W}}$ (Whittaker-féle $\beta$ diverzitás) kisemlős közösséget és annak élöhelyét reprezentáló értékei tekintetében. Minél nagyobb volt az élőhely mozaikossága, annál egyenetlenebb volt a kisemlős közösség fajkészletének eloszlása.

Mindezek alapján bizonyítottnak tartom a habitat szerkezet és a benne élö kisemlős közösség összetételének kapcsolatát, kiemelve, hogy véleményem szerint a kapcsolat összetettsége miatt nem célravezető annak számszerüsítését túlhangsúlyozni.

\subsection{Az erdősáv-rendszer zöld folyosó szerepe a kisemlős metapopulációk fenntartásában}

Táji léptékben tekintve, az általam vizsgált terület egy teljesen átalakított kultúrtáj, ahol az eredeti vegetáció helyén intenzíven kezelt mezőgazdasági területeket találunk. Ebben az agrárterületek dominálta humán térben jellemző tájelemek még a vonalas létesítmények (utak, vasút, árkok, elektromos vezetékek), a települési építmények (lakóépületek, gazdasági épületek) és a mezővédő erdősávok. Elmondható, hogy a táj természetes elemei közül néhány apró gyepfolt kivételével napjainkra semmi nem maradt fenn. A fragmentáció (BÁLDI, 1996) tájléptékben érintette a térséget, melynek következtében a mintegy 3100 ha-os Project terület teljes egészében a természetes élőhelyszigetek közti térré, mátrixszá alakult (SzENTESI \& TÖRÖK, 1996). Paradox módon, csupán azok a mezővédő erdősávok emlékeztetnek az egykori természetes vegetációra, melyeket a táj átalakítását eredményező mezőgazdasági termelés hatékonysága érdekében szintén az ember telepített. 
Az élöhelyek feldarabolódása a populációk szintjén az egy nagy populáció, több kicsi populációvá való alakulásához vezet. A populációméret-csökkenés súlyosan megnöveli a kihalás kockázatát (MARGócZI, 1998). Amennyiben a kialakuló élőhelyfoltok között az adott faj számára átjárható terek maradnak vagy képződnek, akkor a sok kis populáció metapopulációt alkothat. Ennek jelentősége abban áll, hogy kialakulása esetén az adott faj metapopulációja úgy is fennmaradhat, ha közben egyes részpopulációi kihalnak. A metapopuláció fennmaradását alapvetően befolyásolja az élöhelyfoltok minősége és távolsága, a részpopulációk jellemzői (denzitás, korstruktúra), a faj migrációs képessége és a foltok közötti terület vagy mátrix minősége.

Vizsgálataim alapján a terület kisemlős metapopulációinak szempontjából a fenti befolyásoló tényezők hatását tekintve a következőket kell kiemelni:

\section{A részpopulációk élőhelyfoltjainak minősége, mérete és távolsága}

A területen természetes erdőt vagy erdőfoltot nem találunk, az erdei kisemlős fajok ennek ellenére jelen vannak. Élőhelyfoltjaikról -a telepített akácosról és erdősávokról- a több éven át végzett vizsgálatok során bebizonyítottam, hogy alkalmasak az erdei kisemlős-fajok életterét biztosítani, mivel az őket alkotó fák és cserjék megfelelő táplálékot és mikroklimatikus viszonyokat biztosítanak nekik.

Méretüket tekintve az akác erdőfolttal (3F) szemben, az erdei kisemlősök szempontjából, az erdősávok kedvezőtlenebbek, amit a MACARTHUR \& WILSON (1967) - féle szigetbiogeográfia, területhatásként ismert törvényszerüsége is alátámaszt. A sávok ugyanis általában olyan keskenyek $(10-30 \mathrm{~m})$, hogy bennük csak több koronaszint és cserjeszint létesítése esetén találnak élőhelyet az erdei kisemlősfajok.

$\mathrm{Az}$ élőhelyfoltok távolsága az általam vizsgált területen egy speciális kérdés. Az erdősáv-rendszerben lévő, jól struktúrált, erdei kisemlős fajokat rejtő sávok és a $3 \mathrm{~F}$ erdőfolt olykor több kilométer távolságra vannak, ami a fent említett törvényszerüség távolsághatása miatt kedvezötlen, azonban a többi fö- és melléksávon keresztül kapcsolatuk van egymással.

Vizsgálataimmal kimutattam, hogy a kapcsolatban lévő sávpárok és sávhármasok részei közt évről évre fajkicserélődés zajlik, amely elsősorban az erdeiegér fajok és a vöröshátú erdeipocok esetében volt kimutatható. Így az erdősáv-rendszer a kisemlős élőhelyek fragmentációjának ellensúlyozásában kettős szerepet tölt be: az erdősávok nem csak állandó élőhelyei az erdei kisemlösöknek, hanem ökológiai (zöld) folyosó funkciót is ellátnak, és biztosítják a kisemlős élőhelyfoltok közti összeköttetést. Így az erdősávok kisemlős közösségeiben évről-évre fellépő lokális kipusztulások ellenére az erdősáv-rendszer szintjén a kisemlős fajok fennmaradása biztosított.

\section{A foltok közti mátrix minősége a kisemlősök terjedése szempontjából}

Az erdei kisemlösök élőhelyfoltjai közti teret a LAJTA-Projectben mezőgazdasági kultúrák töltik ki. Vizsgálataim bebizonyították, hogy ezek a területek kedvezőtlenebbek a kisemlősök számára. Fajszám, denzitás és diverzitás tekintetében az erdősávok belseje és a mezőgazdasági táblák között végzett összehasonlításaim szerint mindhárom jellemző csökkenő tendenciát mutat a mezőgazdasági terület belseje fele haladva. Csupán a mezőgazdasági táblaszegély sávjában tapasztalunk denzitás növekedést, melynek lehetséges oka a szegélyhatásban keresendő. A denzitás növekedés itt az erdősávhoz képest fajszám csökkenés mellett megy végbe. Ugyanakkor a mezőgazdasági táblaszegély sávjában két hasonló karakterü növényzet találkozik (lucerna-vadföld, tritikále-füves földút, gyepes 
erdősávszegély-tritikále), melyekre a szegélyeffektus érvényesülésének változatai közül az összegző hatás jellemző (GILES, 1978).

Az 50-100 ha-os mezőgazdasági táblák homogén növényzetükkel és időszakonként rendszeresen müvelt (szántott, tárcsázott, vegyszerezett) felületükkel véleményem szerint akadályt (barrier) jelentenek az erdei kisemlősfajok terjedésében, ezért azok az agrárterületek szigeteiként létező erdőfoltokat a mezővédő erdősávok ökológiai folyosó szerepe nélkül nem lennének képesek benépesíteni.

\section{6. ÖSSZEFOGLALÁS}

Dolgozatomban egy intenzív agrárkörnyezet erdősáv-rendszerének kisemlős közösségeit vizsgáltam. A hat évet felölelő kutatás során 23 erdősávban 11202 csapdaéjszakán 11 talajlakó, rovarevő és rágcsáló kisemlős faj 1645 egyedének jelenlétét mutattam ki. Elemeztem a négy, gyakorinak tekinthető faj populációjának diszperzióját, élőhelyhasználatát, ivararányát, dinamikáját az egyes évek közt és éven belül, aggregáltságát és testtömeg viszonyait. Feltártam és összehasonlítottam az erdősávok kisemlős közösségeinek szerkezetét, főbb karakterisztikáit. Rámutattam a kisemlős közösségek és az élőhelyszerkezet kapcsolatára, továbbá feltártam a mezővédő erdősávok, mint zöld folyosók szerepét a kisemlős metapopulációk fenntartásában.

\section{Vizsgálataim tudományos eredményei az alábbiak:}

1. Bizonyítottam, hogy a mezővédő erdősávos agrárterületeken a mezei élőhelyek általánosan elterjedt rágcsálófajain és közösségein (Microtus arvalis, Cricetus cricetus) túl, állandó népessége alakult ki az európai, mérsékelt övi erdők három generalista rágcsálójának is (Apodemus sylvaticus, Apodemus flavicollis, Clethryonomis glareolus), melynek következtében speciális, átmeneti kisemlős közösségek jönnek létre. A közösségekben a közönséges erdeiegér dominanciája jellemző. Kompetítorként leggyakrabban a mezei pocok, erdőfoltokban pedig a sárganyakú erdeiegér jelentkezik.

2. Kimutattam, hogy az Apodemus flavicollis az erdősávos agrárterületen szoros kötődést mutat a fás vegetációhoz, ellentétben az Apodemus sylvaticussal, amely a kultúrsztyepp jellegü agrárterületen is elterjedt.

3. Bemutattam, hogy az akác erdőfolt területén három nyári-őszi hónapban a két Apodemus faj ivararánya éppen ellentétesen változik, ami a hasonló forrásokat használó fajok közti versengés eredménye és stabilis közösségek sajátja. Hasonlóképpen, az erdősávok területén, a fenti két faj mennyiségi viszonyai az évek során is ellentétesen változtak, a kompetíciós viszonyok függvényében.

4. Kimutattam, hogy az egér (Muridae) és pocokfajok (Arvicolidae) populációinak átlagos testtömeg értékei különbözö években érték el maximumukat, ami a táplálékforrás kihasználás különbözőségére utal.

5. Több, hasonló szerkezetü, szomszédos élőhely kisemlős közösségének hasonlóságával bizonyítottam a vegetációszerkezet és a kisemlős közösségek közt esetenként fennálló kapcsolatot, amit a mozaikossági vizsgálatok is megerősítettek.

6. Kimutattam, hogy az erdősávok belsejétől a mezőgazdasági kultúrák irányába haladva a kisemlős közösségek fajszáma és diverzitása csökken (exponenciálisan, ill. lineárisan), ugyanakkor az akácerdő belsejében ezek a jellemzők nem mutatnak trendszerü változást. 
7. A fajkészlet átrendeződésének vizsgálata során bizonyítottam, hogy az erdei kisemlős fajok az agrárterületek szigeteiként tenyésző erdőfoltokat, fásításokat a mezővédő erdősávok ökológiai folyosó szerepe nélkül nem lennének képesek benépesíteni.

\section{IRODALOMJEGYZÉK}

BAUER, K. (1960): Die Säugetiere der Neusiedlersee-Gebites. Bonner Zoologische Beiträge 11: 141342.

BÁLDI A. (1996): Élőhelyek fragmentálódásának hatása állatközösségekre. Természetvédelmi Közlemények 3-4: 103-112.

BÁLDI A., CSORBA G. \& KORSÓs Z. (1995): Magyarország szárazföldi gerinceseinek természetvédelmi szempontú értékelési rendszere. Magyar Természettudományi Múzeum, Budapest, $59 \mathrm{p}$.

BEGON, M. (1979): Investigating animal abundance. - London, 97 p.

BIBER, J-P. (1988): Hedges. Council of Europe, Strasbourg. Planning and Managment Series 1: 64 p.

BudAY P. (1993): A Lajta-Hansági Állami Tangazdaság fácángazdálkodásának vizsgálata és továbbfejlesztésének lehetöségei - Diplomamunka, Sopron, EFE Vadgazdálkodási Tanszék

Canova, L., Maistrello, L. \& Emiliani, D. (1994): Comparativ ecology of the Wood mouse Apodemus sylvaticus in two differing habitats. Zeitschriftf. Säugetierkunde 59: 193-198.

Christian, D. P., Collins, P. T., HANOwski, J. M. \& NiEMI, G. J. (1997): Bird and small mammal use of short-rotation hybrid poplar plantations. Journal of Wildlife Management 61: 171-182. http://dx.doi.org/10.2307/3802426

Corbet, G. \& Ovenden, D. (1982): Pareys Buch der Säugetiere. - Verlag Paul Parey, Hamburg und Berlin

CRANFORD, J.A. \& MALY, M.S. (1986): Habitat Associations Among Small Mammals in an Oldfield Community on Butt Mountain, Virginia. Virginia Journal of Science 37 (3)

CsIZMAZIA GY. (1980): A Tisza magyarországi hullámterén végzett mammológiai-ökofauniszikai vizsgálatok I. Juhász Gyula Tanárképző Főiskola Tudományos Közleményei 1980: 19-38.

DEMETER A. (1979): Kisemlösök populációdinamikája egy erdei fenyvesben - Szakdolgozat, ELTE, Budapest

DEMETER A. (1981): Egyedszámbecslési kisérletek kisemlösökkel - Doktori értekezés, ELTE, Budapest

DEMETER A. (1985): The effect of shampling parameters on reliability of capture-recapture population ensimates of Small rodents a multivariate analysis. In Abstract of the 1st European Biometric Conference, Budapest

DiTTRICH G. (1999): A fácánállomány vizsgálata a LAJTA Project területén - Szakdolgozat, Sopron, SE Vadgazdálkodási Tanszék

FARAGÓ S. (1989): Vizsgálatok a szárnyasvad állati eredetű táplálékbázisáról mezőgazdasági környezetben Magyarországon II. Erdészeti és Faipari Tudományos Közlemények 1989 (2): 153-193.

FARAGÓ S. (1993): Mezőgazdasági módszerekkel folytatott élőhelyjavítás a LAJTA Projectben, mint a fogoly állománydenzitás növelésének egyik módja. Vadgazdálkodási és Szigetközi Halgazdálkodási Konferencia előadásai. 1993. Augusztus 31.

FARAGÓ S. (1994): Fogolypopulációk denzitás-növelésének lehetőségei ökológiai módszerekkel. In.: PALOTÁs G. (szerk.): Előadások és poszterek összefoglalója. I. Kelet-Magyarországi Vad-és Halgazdálkodási-, Természetvédelmi Konferencia, Debrecen: 138-141.

FARAGÓ S. (1997a): Élőhelyfejlesztés az apróvad-gazdálkodásban. Mezőgazda Kiadó, Budapest

FARAGÓ S. (1997b): A fogolypopuláció dinamikája a LAJTA Projectben, 1989-1995. Magyar Apróvad Közlemények 1: 107-132.

FARAGÓ S. (1997c): A fogoly élőhelyválasztása a LAJTA Projectben. Magyar Apróvad Közlemények 1: 133-151. 
FARAGÓ S. (1997d): Összehasonlító mikroklímavizsgálatok fogoly (Perdix perdix)-családok otthonterületében. További adalék az élőhely diverzitás szükségességéhez. Magyar Apróvad Közlemények 1: 153-175.

FARAGÓ, S. (1998): Habitat selection by Grey Partridge (Perdix perdix) in the area of the LAJTA Project (Western Hungary). Gibier Faune Sauvage - Game and Wildlife 15 (4): 481-490.

FARAGÓ, S. (2000): The LAJTA Project - The pilot project of the Hungarian Partridge Conservation Program (HPCP). In: FARAGÓ, S. (szerk.): PERDIX VIII. Proceedings of an International Symposium on Partridges, Quails and Pheasants in the Western Palearctic and Nearctic, Sopron, Hungary, 26-29 October 1998. Magyar Apróvad Közlemények 5: 301-312.

FARAGÓ, S. (2001): The long-term monitoring of Arthropoda food basis of adult wildfowl in the LAJTA PROJECT (Hungary). In: HADJISTERKOTIS, E. (szerk.): Wildlife management in the $21^{\text {st }}$ Century. Abstracts of the XXV. International Congress of the IUGB and IXth International Symposium Perdix, September 3-7. 2001. Lemesos-Cyprus: 92.

FARAGÓ, S. (2002): Dynamics of a grey partridge (Perdix perdix) population in Western Hungary: Effect of a management plan. Game and Wildlife Science 18 (3-4): 425-441.

FARAGÓ S. \& BUDAI P. (1998): A LAJTA Project fogoly (Perdix perdix) populációjának és környezetének vizsgálata 1989-1997. Magyar Apróvad Közlemények 2: 1-250.

Fowler, J. \& COHEN, L. (1986): Statistics for Ornithologists. BTO Guide No. 22. British Trust for Ornithology. Thetford. p. 68-111.

Garcia, F. J., Diaz, M., Alba, J. M., Alonso, C., L., Carbonell, M. L., Carrión, M. L., MONEDERO, C. \& SANTOS, T. (1998): Edge effects and patterns of winter abundance of wood mice Apodemus sylvaticus in Spanish fragmented forests. Acta Theriologica 42 (3): 255-262. http://dx.doi.org/10.4098/AT.arch.98-20

GÁL J. (1965): A mezövédö erdősávok hatásának komplex vizsgálata. Kandidátusi értekezés Sopron

GÁL J. \& KÁLDY J. (1977): Erdösítés. Akadémiai Kiadó, Budapest, pp. 451-603.

GILES, R. H. JR. (1978): Wildlife Managment. W.H. Freeman and Company, San Francisco.

GUBÁNYI, A., HoRVÁTH, GY., MÉSZÁROS, A. \& MÉSZÁROS, F. (2002): Community ecology off small mammals in the territory of the Fertö-Hanság National Park. In: MAHUNKA S. (szerk.): The fauna of the Fertö-Hanság National Park, pp. 799-813.

GYULAI I. (1996): Ökológiai folyosók, zöld folyosók: Tisztázatlan fogalmak a biológiai változatosság megörzésének stratégiájában. - In: HARASZTHY, L. (szerk.): Természet Világa II. pp. 41-44.

HALLE, S. (1993): Wood mice (Apodemus sylvaticus L.) as pioneers of recolonization in a reclaimed area. Oecologia 94: 120-127. http://dx.doi.org/10.1007/BF00317312

HARASZTHY L. (1995): Biológiai sokféleség megörzésének lehetőségei Magyarországon. - WWFfüzetek 8: 14.

HARASZTHY L. (1999): Természeti értékeink megőrzésének lehetőségei az Európai Unióban. - WWFfüzetek 14: 3.

HEALY, W. M. \& BROOKS, R. T. (1988): Small mammal abundance in northern hardwood stands in west Virginia. Journal of Wildlife Management 52: 491-496. http://dx.doi.org/10.2307/3801597

Heske, E.J. \& STEEN, H. (1990): Patterns of microhabitat use by a Microtinae Rodent assemblage in the Rodane Mountains, Norway - Universites of Bergen and Oslo, February, 1990

HÓBER B. (2002): Térinformációs rendszer kialakítása a LAJTA-Project területén. - Diplomamunka, Sopron, NYME Vadgazdálkodási Intézet. 44 pp.

HORVÁTH GY. (1998a): A kisemlősfauna elevenfogó csapdázásos vizsgálata a Mattyi-tó mellett (Baranya megye). Dunántúli Dolgozatok Természettudományos Sorozat 9: 501-509.

HoRVÁTH GY. (1998b): Population dynamics and trappability of four rodent species in a forest habitat. Miscellanea Zoologica Hungarica 12: 107-119.

HORVÁTH GY. (2001): Az északi pocok újabb előfordulása, a Kis-Balaton területén végzett kisemlős ökológiai kutatások előzetes eredményei. Természetvédelmi Közlemények 9: 299-313.

HORVÁTH GY. \& KALMÁR S. (2001): Az Apodemus agrarius populációinak összehasonlító szünbiológiai vizsgálata három különbözö habitatban. Magyar Apróvad Közlemények 6: 335352. 
HORVÁTH GY. \& LANSZKI J. (2000): Két erdei habitat kisemlős együttesének összehasonlító szünbiológiai vizsgálata. Somogyi Múzeumok Közleményei 14.

HoRVÁtH, GY. \& TRÓCSÁNYI, B. (1998): Autumn home range size of Apodemus agrarius and small mammal population dynamics int the rodent assemblage of a Querco-Robori Carpinetum forest habitat. Tiscia 31: 63-69.

HORVÁTH GY., MÁTICS R., TÖlGYESI M. \& TRÓCSÁNYI B. (1996a): Kisemlösök cönológiai vizsgálata egy erdei vegetációban a Dráva-menti síkság területén. Vadbiológia 5: 122-132.

Horváth, Gy., MÁtics, R., TÖlgyesi, M. \& TrócsÁNYI, B. (1996b): Contributions to striped field mouse Apodemus agrarius population dynamics in forest edge habitat. Polish Ecological Studies 22 (3-4): 159-172.

HorvÁth, GY. \& PiNTÉR, V. (2000): Small mammal fauna of two abandoned field habitats, and a spatio-temporal analysis of four rodent populations. Miscellanea Zoologica Hungarica 13: $105-121$.

IUCN, UNEP, WWF (1980): World Conservation Strategy: Living Resource Conservation for Sustainable Development. International Union for Conservation of Nature and Natural Resources, United Nations Environment Programme and World Wildlife Fund Gland, Switzerland

JAMON, M. (1986): The dynamics of Wood mouse (Apodemus sylvaticus) populations in the Camargue. Journal of Zoology, London 208: 569-582.

JÁNOSKA F. (1995a): Bagolyköpet-vizsgálatok eredményei a Hanság és a Mosoni-sík térségéből. Szélkiáltó 10: 21-22.

JÁNOSKA F. (1995b): Fészkelö madárállományok vizsgálata kisalföldi erdösávokban vadgazdálkodási vonatkozásokkal. Kandidátusi Értekezés, Sopron

JÁNOSKA F. (1998): Fészkelő madárközösségek vizsgálata kisalföldi erdősávokban. Ornis Hungarica 8 Suppl. 1: 49-58.

JÁNOSKA F. (1999): Investigations on breeding bird communities in windbreaks in W-Hungary. Abstracts of the XXIV. Congress of the IUGB, Thessaloniki, Greece: 75.

JENSEN, T. S. (1984): Habitat distribution, home range and movements of rodents in mature forest and reforestration. Acta Zoologica Fennica 171: 305-307.

JENSEN, T. S. (1985): Seed-seed predator interactions of European beech, Fagus sylvatica and forest rodents, Clethrionomys glareolus and Apodemus flavicollis. Oikos 44: 149-156. http://dx.doi.org/10.2307/3544056

KARAKAI T. (1999): A LAJTA Project özállományának vizsgálata - Szakdolgozat Sopron, SE Vadgazdálkodási Tanszék

KISS G. L. (1992): Gyomállományok, mint a vad növényi eredetü táplálékának vizsgálata a LAJTA Project területén - Diplomamunka, Sopron, EFE Vadgazdálkodási Tanszék

KOZAKIEWITZ, M. \& JURASINSKA, E. (1998): The role of habitat barriers in woodlot recolonization by small mammals. Holarctic Ecology 12: 106-111.

KöLÜS G. (1969): Mezővédö erdősávok hatása különböző agrobiocönózisok föbb állatpopulációinak kialakulására Kandidátusi értekezés, Keszthely

KÖRNYEZETVÉDELMI ÉS TERÜLETFEJLESZTÉSI MINISZTÉRIUM (1991): Földünkért. Az élet fenntartásának stratégiája.

LELKES A. \& HoRVÁTH GY. (2000): Adatok a Kis-Balaton kisemlős faunájához, különös tekintettel az északi pocok (Microtus oeconomus) előfordulására. Somogyi Múzeumok Közleményei 14: 359-366.

LIRO, A. \& SZACKI, J. (1994): Movements of small mammals along two ecological corridors in suburban Warsaw. Polish Ecological Studies 20 (3-4): 227-231.

LLOYD, M. (1967): Mean crowding. Journal of Animal Ecology 36: 1-30. http://dx.doi.org/10.2307/3012

LOMAN, J. (1991): Do wood mice Apodemus sylvaticus (L.) abandon fields during autumn? Ekologia Polska 39 (2): 221-228.

MACARTHUR, R. H. \& WILSON, E. O. (1967): The theory of island biogegography. - Princeton Univ. Press, Princeton

MAGYAR P. (1961): Alföldfásítás I-II. - Akadémiai Kiadó, Budapest

MARGÓCZI K. (1998): Természetvédelmi biológia. - Egyetemi jegyzet, JATEPRESS p. 38-80. 
MAROSI S. \& SOMOGYI S. (szerk.)(1990): Magyarország kistájainak katasztere I. MTA Földrajztudományi Kutató Intézet, Budapest p. 329-334

MÁRKUS F. (1992): Az intenzív mezögazdaság és földhasználat hatása a természeti értékekre Magyarországon. WWF-füzetek 1: 14.

MÁRKUS F. (1996): A mezőgazdaság hatása a biológiai sokféleségre. In: HARASZTHY, L. (szerk.): Természet Világa II: 39-41.

MAZURKIEWICZ, M. (1994): Factors influencing the distribution of the bank vole in forest habitats. Acta Theriologica 39: 113-126. http://dx.doi.org/10.4098/AT.arch.94-16

Mikes, M. \& HABIJAN, V. (1985): Coenotic Relations of Small Mammals Along the River Tisza. Tiscia (Szeged) 20: 135-143.

Mitchell-Jones, A. J., Amori, G., Bogdanovwicz, W., KryštufeK, B., ReiJndres, P., J., H., Spitzenberger, F., Stubbe, M., Thissen, J. B. M., Vohralík, V. \& Zima, J. (1999): The atlas of European Mammals. T \& AD Poyser Ltd, London.

MitChelL, M. S., KARRIKER, K. S., JONES, E. J. \& LANCIA, R. A. (1995): Small mammal communities associated with pine plantation management of Pocosins. Journal of Wildlife Management 59: 875-881. http://dx.doi.org/10.2307/3801969

Mocz A. (1990): A Lajta-Hansági Állami Tangazdaság mezei özállományának vizsgálata Diplomamunka, Sopron, EFE Vadgazdálkodási Tanszék

NAGY M. (1980): Rágcsáló kisemlősök szerepe tölgyeserdők természetes felújulásában. Acta Biologica Debrecina 17: 7-20.

NAGY P. (2002): A fürj (Coturnix coturnix) és a galambfélék (Columbidae) állományainak vizsgálata a LAJTA Projectben - Szakdolgozat, Sopron, NYME Vadgazdálkodási Tanszék

NÉMETH Cs. (1993): Kisemlös vizsgálatok a LAJTA Project erdösávrendszerében. TDK dolgozat, Sopron, EFE Vadgazdálkodási Tanszék

NÉMETH Cs. (1995a): Kisemlös állományvizsgálatok a LAJTA Project erdösáv-rendszerében. Diplomamunka, Sopron, EFE Vadgazdálkodási Tanszék

NÉMETH Cs. (1997): Kisemlős közösségek vizsgálata a LAJTA Project erdősáv-rendszerében. Magyar Apróvad Közlemények 1: 197-217.

NÉMETH Cs. (2000): Kisemlős közösségek vizsgálata a LAJTA Project erdősáv-rendszerében. Ornis Hungarica 10: 243-253.

NÉMETH F. (szerk.)(1995b): Nemzeti Ökológiai Hálózat. Javaslat a környezet- és természetbarát hasznosításra. - IUCN, Budapest p. 9.

NichOls, J. D. \& CONLEY, W. (1982): Active-season dynamics of a population of Zaphus hudsonius in Michigan. Journal of Mammalogy 63: 422-430. http://dx.doi.org/10.2307/1380439

NiETHAMMER, J. \& KRAPP, F. (1978): Handbuch der Säugetiere Europas. Akademische Verlagsgesellschaft, Wiesbaden 1: 290-449., 2(I): 2-418.

O'FARELL, M. J. (1980): Spatial relationships of rodents in a sagebrush commutity. Journal of Mammalogy 61: 589-605. http://dx.doi.org/10.2307/1380306

PALOTÁs G. (1986): Kisemlösök populációinak és közösségeinek szerkezete és dinamikája a Hortobágyon - Kandidátusi értekezés, Debrecen

PAPP J. L. (1971): Aranyosgadány kisemlősfaunája gyüjtések és bagolyköpet vizsgálatok alapján. Vertebrata Hungarica 12: 69-78.

PÉCSI M. (szerk.)(1975): A Kisalföld és a Nyugat-Magyarországi peremvidék. -Magyarország tájföldrajza 3. Akadémiai Kiadó, Budapest

PeliKán, J. (1970): Sex Ratio in Three Apodemus Species. Zoologické listy 19: 23-34.

PIELOU, E. C. (1966): The measurement of diversity in different types of biological collections. Journal of Theorethical Biology 13: 131-144. http://dx.doi.org/10.1016/0022-5193(66)90013$\underline{0}$

PODANI, J. (1997): Bevezetés a többváltozós biológiai adatfeltárás rejtelmeibe. - Scientia Kiadó, Budapest

PRÉCSÉNYI I. (1995): Alapvetö kutatástervezési, statisztikai és projektértékelési módszerek a szupraindividuális biológiában. Viselkedésökológiai Kutatócsoport KLTE Evolúciós Állattani és Humánbiológiai Tanszék, Debrecen, p. 63. 
REICHHOLF, J. H. (1992): Fejlődéstörténet. - In: GRZIMEK, B. (szerk.)(1992): Emlösök enciklopédiája I. - Lutra Kerko Kft. Budapest

SHANNON, C. E. \& WEAVER, W. (1949): The mathematical theory of communication. - University of Illinois Press, Montana

SZACKI, J. \& LIRO, A. (1991): Movements of small mammals int the heterogeneous landscape. Landscape Ecology 5 (4): 219-224. http://dx.doi.org/10.1007/BF00141436

SZENTESI Á. \& TÖRÖK J. (1996): Állatökológia. Egyetemi jegyzet, Kovásznai Kiadó, Budapest

SZUNYOGHY J.(1955): Kisemlősgyüjtés. Állattani Közlemények 45: 131-138.

SZUNYOGHY J.(1956): Hazataláló képesség vizsgálata kisemlősöknél. Állattani Közlemények 45: 143147.

TÓTHMÉRÉSZ B. (1996): NuCoSa: Programcsomag botanikai, zoológiai és ökológiai vizsgálatokhoz. Scientia Kiadó, Budapest p. 24-83.

TÓTHMÉRÉSZ B. (1998): Kvantitatív ökológiai módszerek a skálafüggés vizsgálatára. In: FEKETE, G. (szerk.): A közösségi ökológia frontvonalai. Scientia Kiadó, Budapest, pp. 145-160.

UJHELYI P. (1994): A magyarországi vadonélő emlösállatok határozója. MME, Budapest 8 pp.

WEILE, C. (1996): Habitatwahl von Kleinsäugern in Hegebüschen. Beiträge zur Jagd- und Wildforschung 21: 311-318. 